\title{
Occurrence and Transport of Agricultural Chemicals in Leary Weber Ditch Basin, Hancock County, Indiana, 2003-04
}

By Nancy T. Baker, Wesley W. Stone, John T. Wilson, and Michael T. Meyer

National Water-Quality Assessment Program

Scientific Investigations Report 2006-5251 


\title{
U.S. Department of the Interior \\ DIRK KEMPTHORNE, Secretary
}

\author{
U.S. Geological Survey \\ Mark D. Myers, Director
}

U.S. Geological Survey, Reston, Virginia: 2006

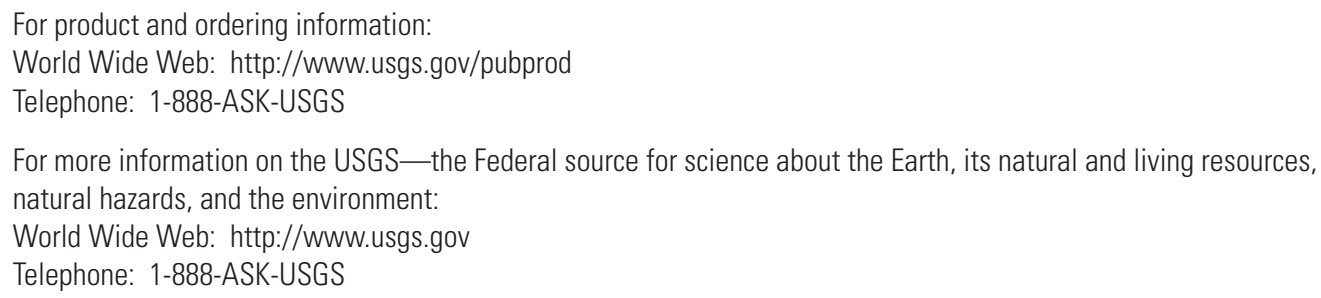

Any use of trade, product, or firm names is for descriptive purposes only and does not imply endorsement by the U.S. Government.

Although this report is in the public domain, permission must be secured from the individual copyright owners to reproduce any copyrighted materials contained within this report.

Suggested citation:

Baker, N.T., Stone, W.W., Wilson, J.T., and Meyer, M.T., 2006, Occurrence and Transport of Agricultural Chemicals in Leary Weber Ditch Basin, Hancock County, Indiana, 2003-04: U.S. Geological Survey Scientific Investigations Report 2006-5251, 44 p. 


\section{Foreword}

The U.S. Geological Survey (USGS) is committed to providing the Nation with credible scientific information that helps to enhance and protect the overall quality of life and that facilitates effective management of water, biological, energy, and mineral resources (http://www.usgs.gov/). Information on the Nation's water resources is critical to ensuring long-term availability of water that is safe for drinking and recreation and is suitable for industry, irrigation, and fish and wildlife. Population growth and increasing demands for water make the availability of that water, now measured in terms of quantity and quality, even more essential to the long-term sustainability of our communities and ecosystems.

The USGS implemented the National Water-Quality Assessment (NAWQA) Program in 1991 to support national, regional, State, and local information needs and decisions related to water-quality management and policy (http://water. usgs.gov/nawqa). The NAWQA Program is designed to answer: What is the condition of our Nation's streams and ground water? How are conditions changing over time? How do natural features and human activities affect the quality of streams and ground water, and where are those effects most pronounced? By combining information on water chemistry, physical characteristics, stream habitat, and aquatic life, the NAWQA Program aims to provide science-based insights for current and emerging water issues and priorities. From 1991-2001, the NAWQA Program completed interdisciplinary assessments and established a baseline understanding of water-quality conditions in 51 of the Nation's river basins and aquifers, referred to as Study Units (http://water.usgs.gov/ nawqa/studyu.html).

Multiple national and regional assessments are ongoing in the second decade (2001-2012) of the NAWQA Program as 42 of the 51 Study Units are reassessed. These assessments extend the findings in the Study Units by determining status and trends at sites that have been consistently monitored for more than a decade and filling critical gaps in characterizing the quality of surface water and ground water. For example, increased emphasis has been placed on assessing the quality of source water and finished water associated with many of the Nation's largest community water systems. During the second decade, NAWQA is addressing five national priority topics that build an understanding of how natural features and human activities affect water quality and establish links between sources of contaminants, the transport of those contaminants through the hydrologic system, and the potential effects of contaminants on humans and aquatic ecosystems. Included are topics on the fate of agricultural chemicals, effects of urbanization on stream ecosystems, bioaccumulation of mercury in stream ecosystems, effects of nutrient enrichment on aquatic ecosystems, and transport of contaminants to public-supply wells. These topical studies are conducted in those Study Units most affected by these issues; they comprise a set of multi-Study-Unit designs for systematic national assessment. In addition, national syntheses of information on pesticides, volatile organic compounds (VOCs), nutrients, selected trace elements, and aquatic ecology are continuing.

The USGS aims to disseminate credible, timely, and relevant science information to address practical and effective water-resource management and strategies that protect and restore water quality. We hope this NAWQA publication will provide you with insights and information to meet your needs and will foster increased citizen awareness and involvement in the protection and restoration of our Nation's waters.

The USGS recognizes that a national assessment by a single program cannot address all water-resource issues of interest. External coordination at all levels is critical for costeffective management, regulation, and conservation of our Nation's water resources. The NAWQA Program, therefore, depends on advice and information from other agenciesFederal, State, regional, interstate, Tribal, and local—as well as nongovernmental organizations, industry, academia, and other stakeholder groups. Your assistance and suggestions are greatly appreciated.
Robert M. Hirsch Associate Director for Water 


\section{Contents}

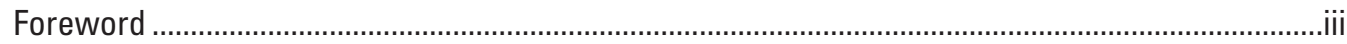

Abstract

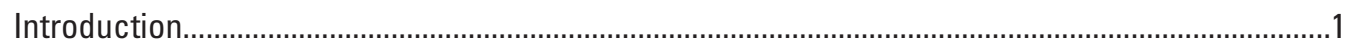

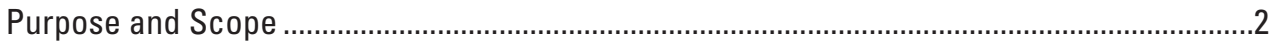

Description of Basin and Sampling Sites ..................................................................................

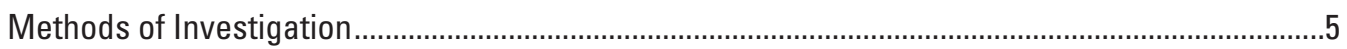

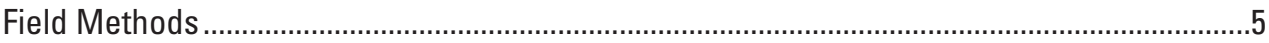

Laboratory Analyses, Data Presentation, and Quality-Control Assurance................................8

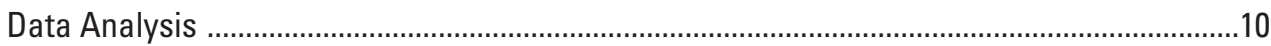

Occurrence of Agricultural Chemicals in Leary Weber Ditch Basin ..............................................11

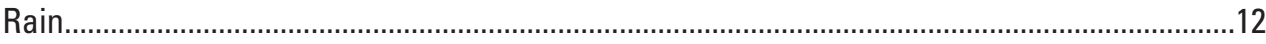

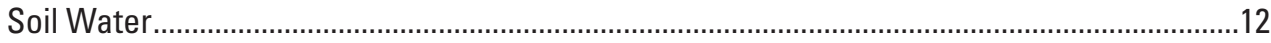

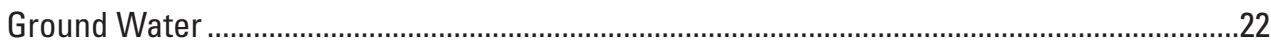

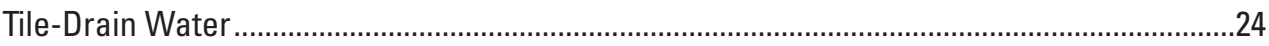

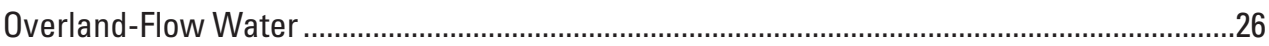

Leary Weber Ditch ........................................................................................................................26

Transport of Agricultural Chemicals in Leary Weber Ditch Basin....................................................27

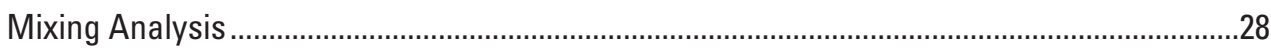

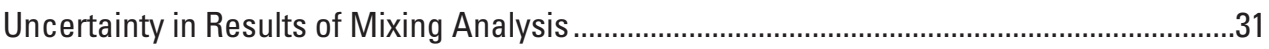

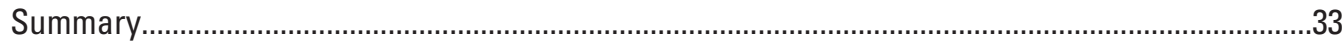

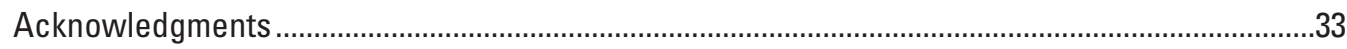

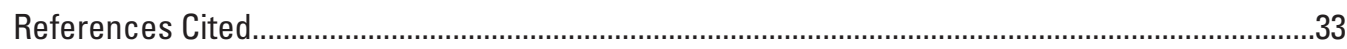

\section{Figures}

\section{1.-2. Maps showing:}

1. Location of Leary Weber Ditch Basin, Indiana, and sampling sites within the basin

2. Approximate tile-drain locations in Leary Weber Ditch Basin, Indiana ..............................4

3. Graphs showing storms targeted for water-quality sampling in Leary Weber Ditch and in the hydrologic compartments of Leary Weber Ditch Basin, Indiana in relation to: (A) streamflow at U.S. Geological Survey streamflow-gaging station Leary Weber Ditch at Mohawk, IN (03361638), (B) agricultural-chemical group sample-collection times for each hydrologic compartment, and (C) water levels in a well screened in the soil horizon at the North site with sample-collection times in the soil-water and ground-water hydrologic compartments.

4. Diagram showing depths of the screened intervals of wells used to sample soil water and ground water with relative distribution of particle sizes in soil cores sampled at the North and South sites in Leary Weber Ditch Basin, Indiana

5. Example standard schematic boxplot showing central tendency and variability of water-quality concentrations.

6. Diagrams showing quality-control results for field-blank samples for pesticides, nutrients, and major ions collected in Leary Weber Basin, Indiana, 2003-04 


\section{Figures-Continued}

7. Graphs showing quality-control results for equipment-replicate samples for (A) pesticides, (B) nutrients, and (C) major ions collected in Leary Weber Ditch Basin, Indiana, 2003-04

8. Boxplot showing distribution of potassium concentrations at selected ranges of flow duration and streamflow for U.S. Geological Survey streamflow-gaging station at Mohawk, IN (03361638)

9. Graph showing frequency of detection of selected pesticide parent (in bold) and pesticide degradate compounds for Leary Weber Ditch and for each hydrologic compartment sampled in Leary Weber Ditch Basin, Indiana, 2003-04 ..........13

10. Boxplots showing distribution of concentrations of selected pesticide parent and pesticide degradate compounds in Leary Weber Ditch and in each hydrologic compartment sampled in Leary Weber Ditch Basin, Indiana, 2003-04

11. Graphs showing relation of selected pesticide concentrations to streamflow for the hydrologic compartments sampled in Leary Weber Ditch Basin, Indiana, 2003-04

12. Boxplots showing distribution of nutrient concentrations in Leary Weber Ditch and in each hydrologic compartment sampled in Leary Weber Ditch Basin, Indiana, 2003-04

13.-14. Graphs showing:

13. Concentration of selected pesticide parent and pesticide degradate compounds in lysimeter and well samples collected in the soil-water and ground-water hydrologic compartments in Leary Weber Ditch Basin, Indiana, 2004.

14. Concentrations of nitrate plus nitrite $(\mathrm{N})$ in lysimeter and well samples collected in the soil-water and ground-water hydrologic compartments in Leary Weber Ditch Basin, Indiana, 2004.

15. Diagram showing comparison of relative percentages of major ions in (A) soil water and ground water and (B) tile-drain, overland-flow, and Leary Weber Ditch water in Leary Weber Ditch Basin, Indiana, 2003-04

16.-18. Graphs showing:

16. Relation of selected nutrient concentrations to streamflow for the hydrologic compartments sampled in the Leary Weber Ditch Basin, Indiana, 2003-04

17. Comparison of alachlor concentrations measured in rain and overland-flow water during storm 5 in Leary Weber Ditch Basin, Indiana, 2004

18. Storm hydrographs for U.S. Geological Survey streamflow-gaging station at Mohawk, IN (03361638), showing estimated relative contribution of overland flow and tile-drain flow to Leary Weber Ditch and maximum 1-hour rainfall intensity for selected storms, 2003-04. 


\section{Tables}

1. Pesticide parent compounds and pesticide degradates analyzed for in water samples from Leary Weber Ditch Basin, Indiana, 2003-04...

2. Frequency of detection for selected pesticide parent compounds and pesticide degradates for Leary Weber Ditch and each hydrologic compartment sampled in Leary Weber Ditch Basin, Indiana, 2003-04 .

3. Comparison of rain volume for Leary Weber Ditch Basin and streamflow at U.S. Geological Survey streamflow-gaging station at Mohawk, IN (03361638) for selected storms, 2003-04

4. Estimates of overland flow contributions to Leary Weber Ditch, Indiana, for selected storms, 2003-04

\section{Conversion Factors and Datum}

\begin{tabular}{|c|c|c|}
\hline Multiply & By & To obtain \\
\hline \multicolumn{3}{|c|}{ Length } \\
\hline inch (in.) & 2.54 & centimeter $(\mathrm{cm})$ \\
\hline inch (in.) & 25.4 & millimeter (mm) \\
\hline foot (ft) & 0.3048 & meter $(\mathrm{m})$ \\
\hline mile (mi) & 1.609 & kilometer (km) \\
\hline \multicolumn{3}{|c|}{ Area } \\
\hline acre & 0.4047 & hectare (ha) \\
\hline acre & 0.004047 & square kilometer $\left(\mathrm{km}^{2}\right)$ \\
\hline square mile $\left(\mathrm{mi}^{2}\right)$ & 259.0 & hectare (ha) \\
\hline square mile $\left(\mathrm{mi}^{2}\right)$ & 2.590 & square kilometer $\left(\mathrm{km}^{2}\right)$ \\
\hline \multicolumn{3}{|c|}{ Volume } \\
\hline gallon (gal) & 3.785 & liter (L) \\
\hline gallon (gal) & 0.003785 & cubic meter $\left(\mathrm{m}^{3}\right)$ \\
\hline cubic foot $\left(\mathrm{ft}^{3}\right)$ & 0.02832 & cubic meter $\left(\mathrm{m}^{3}\right)$ \\
\hline \multicolumn{3}{|c|}{ Flow rate } \\
\hline cubic foot per second $\left(\mathrm{ft}^{3} / \mathrm{s}\right)$ & 0.02832 & cubic meter per second $\left(\mathrm{m}^{3} / \mathrm{s}\right)$ \\
\hline gallon per minute (gal/min) & 0.06309 & liter per second $(\mathrm{L} / \mathrm{s})$ \\
\hline inch per hour (in/h) & 0.0254 & meter per hour $(\mathrm{m} / \mathrm{h})$ \\
\hline
\end{tabular}

Vertical coordinate information is referenced to the North American Vertical Datum of 1998 (NAVD 88).

Altitude, as used in this report, refers to distance above the vertical datum.

Concentrations of chemical constituents in water are given either in milligrams per liter (mg/L) or micrograms per liter $(\mu \mathrm{g} / \mathrm{L})$. 


\title{
Occurrence and Transport of Agricultural Chemicals in Leary Weber Ditch Basin, Hancock County, Indiana, 2003-04
}

\author{
By Nancy T. Baker, Wesley W. Stone, John T. Wilson, and Michael T. Meyer
}

\section{Abstract}

Leary Weber Ditch Basin, Hancock County, Indiana, is one of seven first-order basins selected from across the United States as part of the Agricultural Chemicals: Source, Transport, and Fate study conducted by the National Water-Quality Assessment Program of the U.S. Geological Survey. The nationwide study was designed to increase the understanding of the links between the sources of water and agricultural chemicals (nutrients and pesticides) and the transport and fate of these chemicals through the environment.

Agricultural chemicals were detected in Leary Weber Ditch and in every associated hydrologic compartment sampled during 2003 and 2004. Pesticides were detected more frequently in samples collected from overland flow and from the ditch itself and less frequently in ground-water samples. The lowest concentrations of pesticides and nutrients were detected in samples of rain, soil water, and ground water. The highest concentrations of pesticides and nutrients were detected in samples of tile-drain water, overland flow, and water from Leary Weber Ditch. Samples collected from the tile drain, overland flow and Leary Weber Ditch soon after chemical applications to the fields and coincident with rainfall and increased streamflow had higher concentrations of pesticides and nutrients than samples collected a longer time after the chemicals were applied.

A mass-balance mixing analysis based on potassium concentrations indicated that tile drains are the primary contributor of water to Leary Weber Ditch, but overland flow is also an important contributor during periods of high-intensity rainfall. When maximum rainfall intensity was 0.5 inches per hour or lower, overland flow contributed about 10 percent and tile drains contributed about 90 percent of the flow to Leary Weber Ditch. When maximum rainfall intensity was 0.75 inches per hour or greater, overland flow contributed about 40 percent and tile drains contributed about 60 percent of the flow to the ditch. Ground-water flow to Leary Weber Ditch was negligible.

Tile drains are an important agricultural-chemical transport path to Leary Weber Ditch, based on the hydrologic contributions of overland flow and tile drains to the ditch. Overland flow is also an important agricultural-chemical transport pathway during high-intensity rainfall; however, storms with high-intensity rainfall are sporadic throughout the year. Tile drains and the soil water moving to the tile drains are the primary transport pathway for agricultural-chemical transport to Leary Weber Ditch during most storms as well as between storms.

\section{Introduction}

Leary Weber Ditch Basin in Hancock County, Indiana, is one of seven first-order basins selected from across the United States as part of the Agricultural Chemicals: Source, Transport, and Fate Team (ACT) study (Capel and others, 2004) conducted by the National Water-Quality Assessment (NAWQA) Program of the U.S. Geological Survey (USGS). The goal of the ACT study is to assess the fate and transport of chemicals applied to crops in agricultural basins across the Nation. Chemicals selected for nationwide ACT study include nutrients (nitrogen and phosphorus), major ions, and about 43 commonly used pesticides and 39 degradation products (including triazine herbicides such as atrazine and simazine, acetanilide herbicides such as acetochlor and metolachlor, and organophosphorus insecticides such as chlorpyrifos and diazinon). Because the herbicide glyphosate is so important in the Midwest, glyphosate and its degradate aminomethylphosphonic acid (AMPA) also were selected for analysis in the Leary Weber Ditch study in 2004 as part of the USGS Toxic Substances Hydrology Program.

The basins in the ACT study represent a variety of agricultural settings with different crop types and agricultural practices related to tillage, irrigation, artificial drainage, and chemical use, as well as a range of landscapes with different geology, soils, topography, climate, and hydrology (Capel and others, 2004). Leary Weber Ditch Basin was selected for study because it is typical of an artificially drained (subsurface tile drains) Midwestern basin with corn and soybean row cropping. In areas with poorly drained soils, tile drains are used to 
facilitate access to and cultivation of agricultural land. During the 1980s, the U.S. Department of Agriculture (USDA) estimated that approximately 50 percent of all cropland in Indiana was drained; tiles drain approximately 70 percent of that cropland. The USDA estimated that Indiana ranked second in the U.S. in total land area where artificial surface and subsurface drainage is used (U.S. Department of Agriculture, 1987).

The ACT study is designed to increase the understanding of the links between the sources of water and agricultural chemicals (nutrients and pesticides) and the fate and transport of these chemicals through the environment. Understanding the fate and transport of these chemicals in the study basins may help predict the fate and transport of agricultural chemicals in other agricultural areas. This information will help managers target the implementation of best management practices to those hydrologic compartments that are the most conducive to the transport of agricultural chemicals.

\section{Purpose and Scope}

This report documents the occurrence of agricultural chemicals in Leary Weber Ditch and in the major hydrologic compartments of the Leary Weber Ditch Basin during 2003 and 2004. Hydrologic compartments that contribute water and agricultural chemicals to Leary Weber Ditch are rain water, overland-flow water, soil water, tile-drain water, and ground water. Water samples were collected during four storms in 2003 and three storms in 2004 from the Tile Drain, Overland Flow, and Leary Weber Ditch sites. In addition, stable-flow samples were collected between storms at the Tile Drain and Leary Weber Ditch sites. Weekly composite rain samples were collected for 13 weeks in 2003 and 2004. Soil-water and ground-water samples were collected at selected times during 2003 and 2004. The samples were analyzed for selected pesticides, nutrients, and major ions. This report also describes the transport of water and chemicals from the major hydrologic compartments to Leary Weber Ditch based on a mass-balance mixing analysis and analyses of hydrologic and chemical data from each of the hydrologic compartments.

\section{Description of Basin and Sampling Sites}

Leary Weber Ditch is a $2.73 \mathrm{mi}^{2}$ intensively farmed drainage basin dominated by poorly drained soils in Hancock County, east-central Indiana (fig. 1). The USGS maintains streamflow gaging station 03361638, Leary Weber Ditch at Mohawk, IN (hereafter referred to as the gaging station). Agriculture is the principal land use, with 87 percent of the total land area in row crops. Leary Weber Ditch is an intermittent stream and a tributary to Sugar Creek. The ditch has been dredged along much of its reach to facilitate drainage of the shallow water table. Successful farming requires lowering the water table and removing ponded water by artificially draining the fields through tiles. Flow in Leary Weber Ditch is sustained primarily from tile-drain contributions. Large changes in flow are tied to snowmelt and rainfall, with flow diminishing quickly between periods of precipitation. A more complete description of the basin can be found in Lathrop (2006).

Tile-drain systems are extensive in the basin; field reconnaissance showed 58 tile-drain outlets along the 2.86-mi length of Leary Weber Ditch. This number of outlets is conservative because $0.3 \mathrm{mi}$ of the ditch was not accessible during the reconnaissance. The drains typically are installed 3 to $4 \mathrm{ft}$ below the land surface, with an average outlet spacing of $200 \mathrm{ft}$. Tile-drain outlets represent individual tiles or collector tiles that combine discharge water from a network of tiles that may drain several fields. Approximate locations of tile drains in the basin are shown in figure 2. Tile locations were derived from landowner recollection, tile-drain outlets, and infrared aerial photography. Because it was not possible to verify tile locations derived from infrared aerial photography, precedence for estimating locations was given to landowner recollection and tile-drain outlets.

The Leary Weber Ditch Basin is topographically flat. A few land areas adjacent to the ditch have overland runoff; areas farther away hold ponded water, unless they too are drained by tile drains. The areas where overland runoff can occur are usually small field-size depressions that drain directly into the ditch, commonly through a culvert that runs beneath the berm of the ditch bank. The Overland Flow site is one of 17 overland flow culverts along the length of Leary Weber Ditch. The Overland Flow site is a 3.5-acre depression with a culvert for drainage at the mouth. The contributing area for runoff is variable and dependent upon the magnitude and intensity of rainfall. Field observations during rainfall indicate that runoff occurs mainly as sheet and rivulet flow to the discharge point. The potential contributing areas of the other 16 culverts were not determined.

A sampling plan was established so that chemicals in Leary Weber Ditch Basin could be accounted for from their point of entry into the basin, their storage or degradation within the basin, or until their departure by flow out of the basin through Leary Weber Ditch (Lathrop, 2006). A wide variety of water-quality sampling sites were established throughout the basin to evaluate the occurrence and movement of water and chemicals into Leary Weber Ditch and between the hydrologic compartments: rain, soil water, ground water, tile-drain water, and overland-flow water. Five monitoring sites were established to characterize Leary Weber Ditch and the various hydrologic compartments: the North, South, Tile Drain, Overland Flow, and Leary Weber Ditch sites (fig. 1). The North site was equipped to monitor rain quantity and quality, and both the North and South sites were equipped to monitor soil-water levels, soil-water quality and ground-water quality. The Tile Drain and Overland Flow sites were equipped to monitor both flow and quality of the water flowing from those hydrologic compartments. The Leary Weber Ditch site was equipped to monitor flow and water quality. A moredetailed site and instrumentation list is available in appendix 1 of Lathrop (2006). 


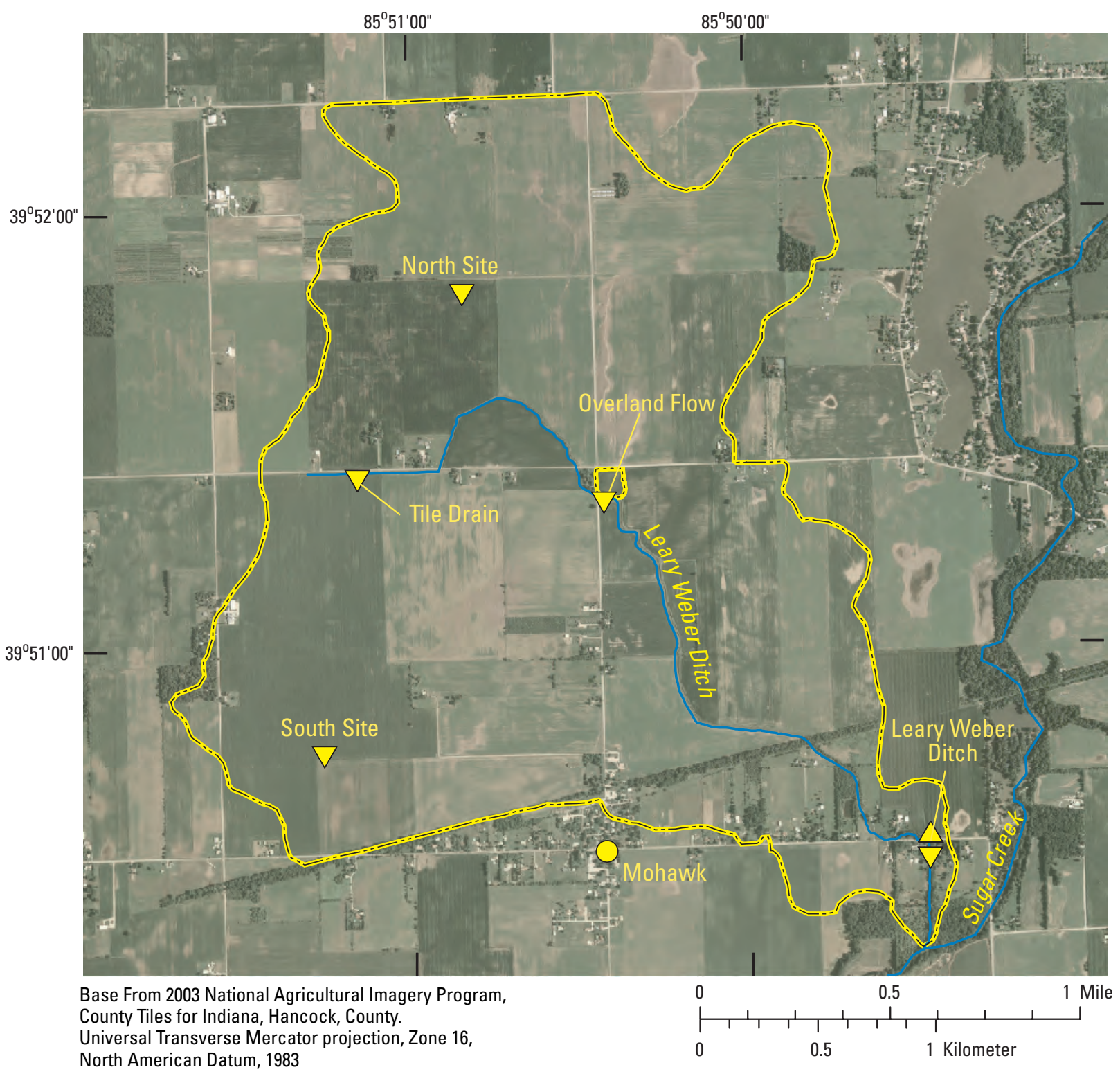

\section{EXPLANATION}

County boundary

Basin boundary

Overland Flow basin boundary

Town

$\nabla \quad$ Water-quality station

$\triangle \quad$ Streamflow-gaging station

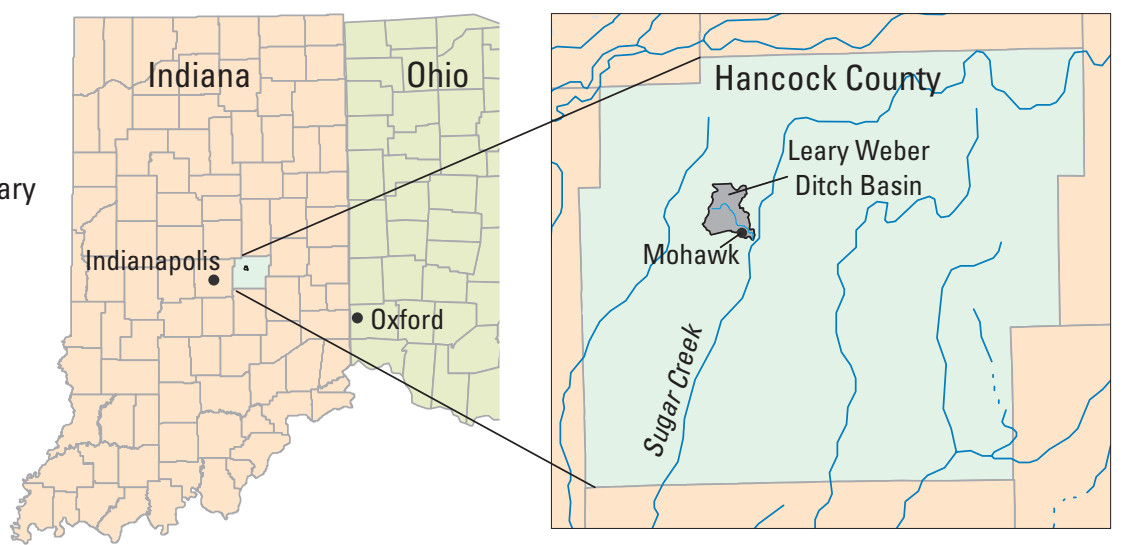

Figure 1. Location of Leary Weber Ditch Basin, Indiana, and sampling sites within the basin. 


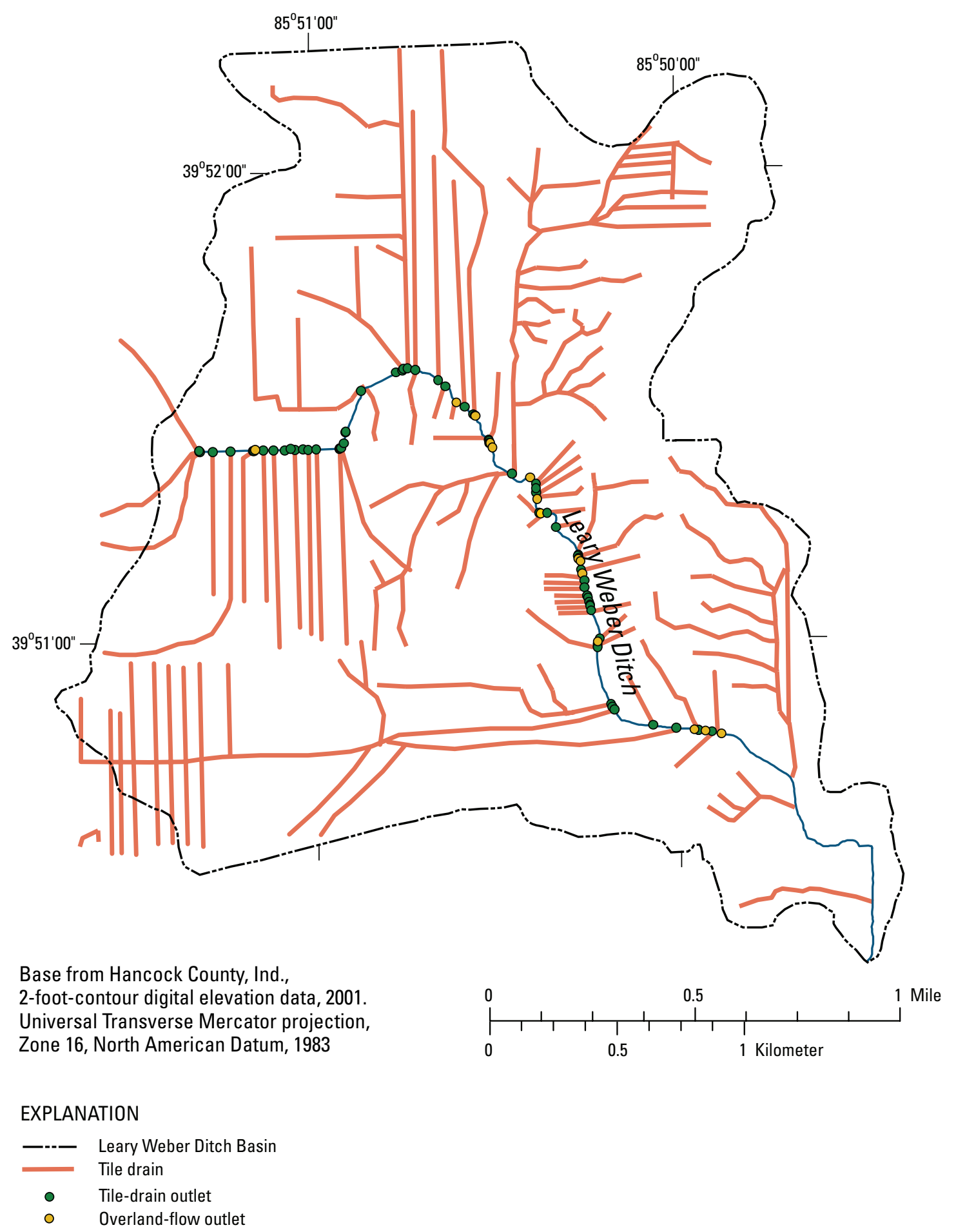

Figure 2. Approximate tile-drain locations in Leary Weber Ditch Basin, Indiana 
The crops and agricultural practices were the same for the fields at the North, South, Tile Drain, and Overland Flow sites during 2003 and 2004. Corn was grown on the study-site fields in 2003. Fertilizer as anhydrous ammonia was applied to the fields at the North, South, Tile Drain, and Overland Flow sites in late April 2003. The herbicides atrazine and acetochlor were applied to those fields in mid-May 2003. Soybeans were grown in the study-site fields in 2004. Glyphosate was applied to those fields in mid-May 2004. All of the crops in study-site fields were harvested in late October and early November of both years. More-detailed estimates of chemical usage for the entire basin for 2003 and 2004 are given in Lathrop (2006).

\section{Methods of Investigation}

Methods used for this study encompass field activities, laboratory procedures, and data analysis. Discussion of the field-activity methods includes the water sampling plans used for each hydrologic compartment in the study. Discussion of laboratory-procedure methods includes references to the preparation and handling of the samples and the analytical procedures used for the targeted chemicals. Water samples were analyzed for pesticides, nutrients, and major ions. Discussion of data-analysis methods includes the description of a mass-balance mixing analysis used in this report.

\section{Field Methods}

Water samples were collected manually or by automatic sampler throughout the planting (April-May), growing (June-September), and harvest (October-November) periods in 2003 and 2004. Discrete water samples were collected by automatic sampler from the Tile Drain, Overland Flow, and the Leary Weber Ditch sites during storms. For chemical analysis, three to five samples, based on their relation to the rise, peak, and recession of flow were selected from each storm. Samples were collected throughout the growing season during four storms in 2003 and during three storms in 2004 (fig. 3A). Because of equipment failure, tile-drain samples were not collected during most of storm 3 in 2003. Overland-flow samples were collected only during storms 4 (partial collection), 5, and 6. There was no surface runoff at the Overland-Flow site during storms 1, 2, and 7. The Overland Flow site instrumentation was flooded during storms 3 and 4 (partial collection), limiting the number of overland-flow samples collected during these storms. Samples collected during storm 7 were analyzed only for nutrients. Between storms and during periods of stable flow, water samples were collected manually at the Tile Drain and the Leary Weber Ditch sites.
Discrete samples were collected from lysimeters (pan and suction) and wells at selected times during 2004 (fig. 3B and C). Pan lysimeters are designed to intercept water moving down the soil profile through macropores. Pan lysimeters (installed only at the North site) were constructed by inserting a 1- $\mathrm{ft}^{2}$ flat pan into the soil profile, $2 \mathrm{ft}$ below the land surface. Soil water drained by gravity into the pan; from there, it drained into a collection chamber that could be evacuated for sampling with a peristaltic pump. Suction lysimeters are designed to pull water from the soil matrix. Suction lysimeters were constructed with a combination internal chamber and porous ceramic cup at one end, and sampling tubes at the other end. Samples were collected by applying suction to the lysimeter, thereby creating a negative pressure in the internal chamber and drawing soil moisture through the ceramic cup into the internal chamber. Suction was applied to the lysimeter 24 hours prior to evacuating the internal chamber to allow enough time for the soil moisture to be drawn into it. Suctionlysimeter samples were collected from the North and South sites at depths of 3,4,5, and $6 \mathrm{ft}$ below the land surface.

Wells at the North and South sites were installed to collect samples from soil water and ground water in 2003 and 2004. At these two sites, the first appearance of saturated sand-and-gravel aquifer material was generally $9 \mathrm{ft}$ or greater below land surface (fig. 4). The wells installed with screens less than $9 \mathrm{ft}$ below land surface were used to characterize water in the soils and the shallow water table. The wells installed with screens greater than $9 \mathrm{ft}$ below land surface were used to characterize ground water. Screen lengths in all wells were $2 \mathrm{ft}$. This allowed discrete sampling from the following approximate intervals, 3 to $5 \mathrm{ft}, 5$ to $7 \mathrm{ft}, 7$ to $9 \mathrm{ft}, 9$ to $11 \mathrm{ft}$, and 12 to $14 \mathrm{ft}$ below land surface. Soil-water and groundwater samples were analyzed for pesticides, nutrients, and major ions.

A refrigerated wet-deposition sampler at the North site collected weekly composite rain samples for 13 weeks in 2003 and 2004; these samples were analyzed for pesticides. Rain samples were not analyzed for major ions or nutrients in 2003. Rain samples were analyzed for nitrate in 2004 but were not analyzed for major ions or other nutrients. Rain samples were analyzed only if there was enough rain water collected for the analytical method.

The timing of tile-drain, overland-flow, and Leary Weber Ditch water-quality sample collection was targeted at characterization of agricultural-chemical movement during storms throughout the growing season and not on a fixed frequency during 2003 and 2004. In contrast, the soil-water and groundwater sample collection was done on a fixed frequency, regardless of the timing of the storms. The tile-drain, overland-flow, and Leary Weber Ditch samples may be biased high relative to soil-water and ground-water samples because storms were targeted and sampling was not done on a fixed frequency. 
A

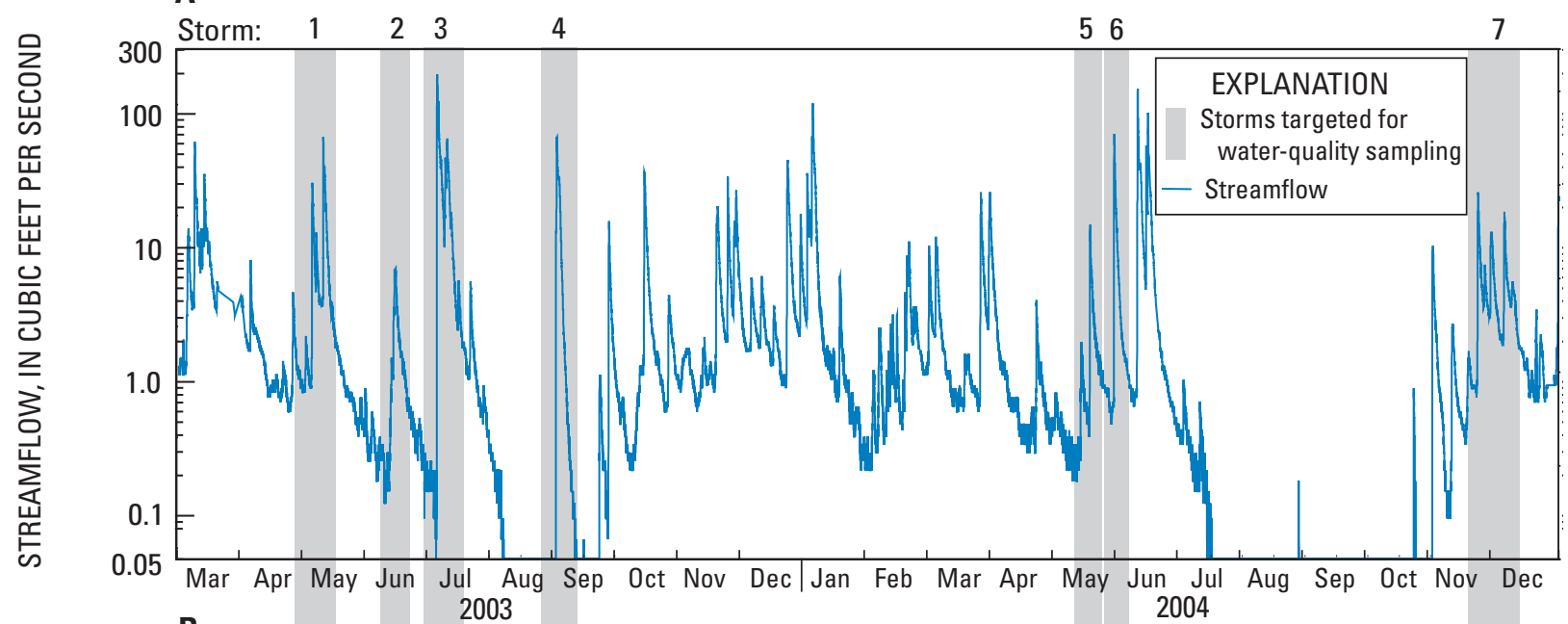

B
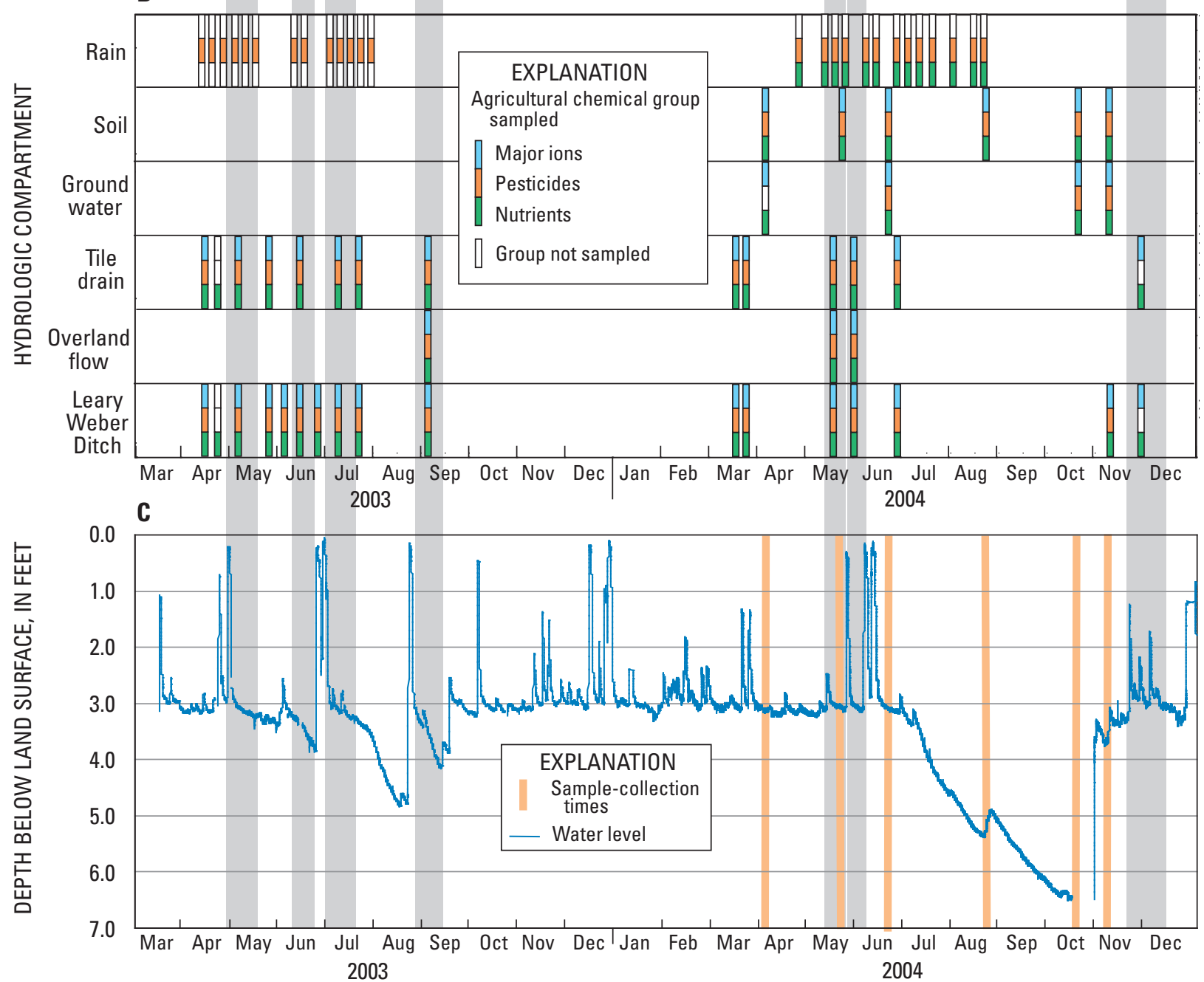

Figure 3. Storms targeted for water-quality sampling in Leary Weber Ditch and in the hydrologic compartments of Leary Weber Ditch Basin, Indiana in relation to: (A) streamflow at U.S. Geological Survey streamflow-gaging station Leary Weber Ditch at Mohawk, IN (03361638), (B) agricultural-chemical group sample-collection times for each hydrologic compartment, and $(\mathrm{C})$ water levels in a well screened in the soil horizon at the North site with sample-collection times in the soil-water and ground-water hydrologic compartments. 

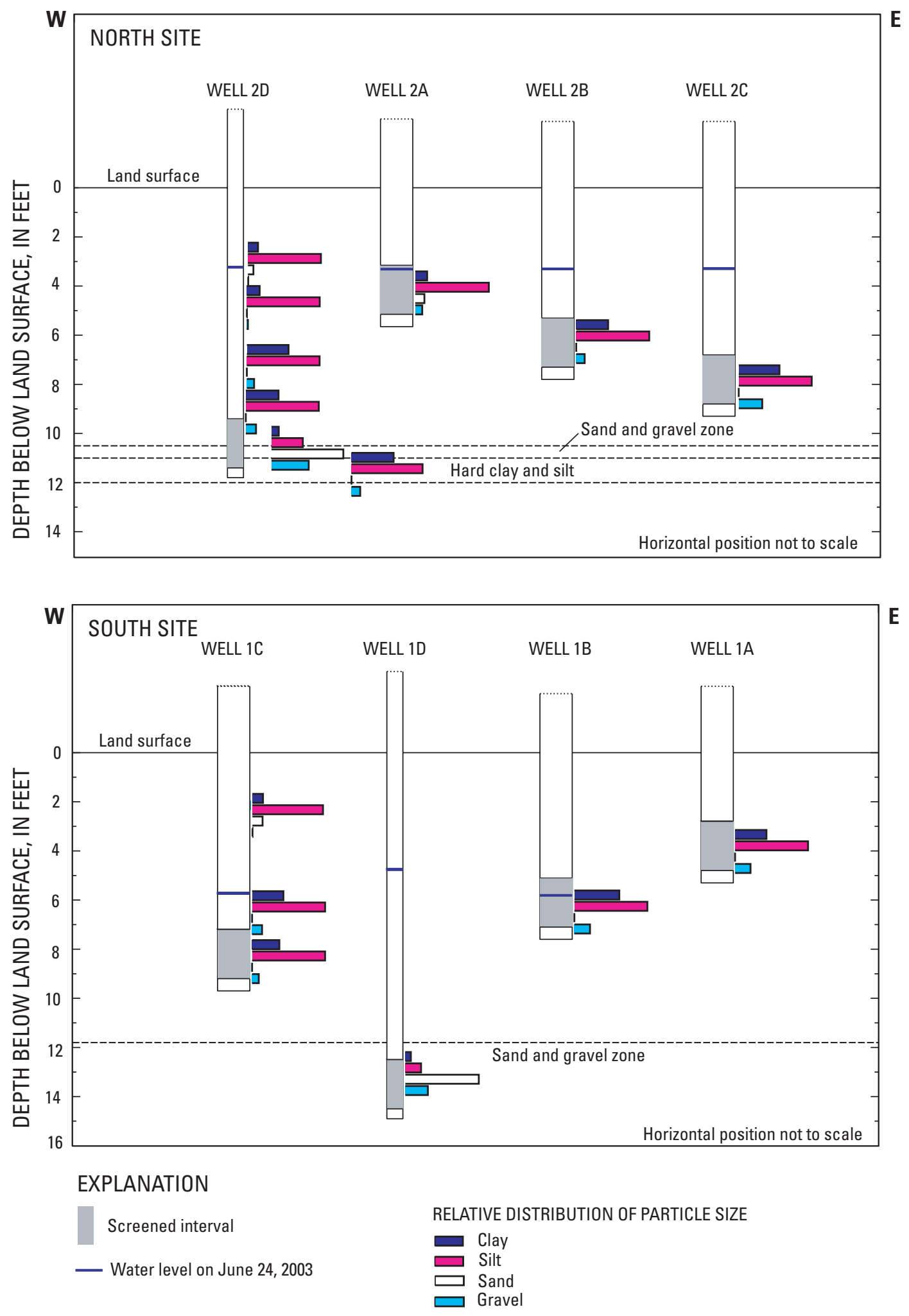

Figure 4. Depths of the screened intervals of wells used to sample soil water and ground water with relative distribution of particle sizes in soil cores sampled at the North and South sites in Leary Weber Ditch Basin, Indiana. 


\section{Laboratory Analyses, Data Presentation, and Quality-Control Assurance}

The handling, filtering, and preparation of water samples followed standard USGS sample-collection procedures (U.S. Geological Survey, variously dated). Samples were iced and shipped overnight for analysis at the USGS National Water Quality Laboratory (NWQL) in Denver, Colo., and the Organic Geochemistry Research Laboratory (OGRL) in Lawrence, Kans. NWQL analyzed the water samples for major ions, nutrients, and pesticides, following the methods described by Fishman (1993), Fishman and Friedman (1989), and the American Public Health Association (1998). Nitrate concentrations reported here are the combination of nitrate and nitrite as nitrogen $(\mathrm{N})$. Of 163 samples analyzed for nitrite plus nitrate and nitrite only, the average contribution of nitrite to nitrate plus nitrite was 0.8 percent, with a median of 0.0 percent. Therefore, the use of nitrate plus nitrite to represent nitrate concentrations appears valid. OGRL analyzed the water samples for pesticide degradates, following methods described in Lee and Strahan (2003). In addition, OGRL analyzed for glyphosate, following the methods described in Lee and others (2002).

The NWQL and OGRL place and store analytical results in the USGS National Water Information System (NWIS). The water-quality data used in this report were retrieved from NWIS on October 27, 2005. The unedited pesticide, nutrient, and major ion data are available in USGS Digital Data Series 214 at URL http://pubs.usgs.gov/ds/2006/214/.

The unedited data were processed to facilitate analysis and presentation in this report. Specifically, the data were edited so that all values with a "less than" $(<)$ remark code (not detected) were set to a zero value. All values with a remark code of "E" (estimated value) were unchanged in the editing process. Reporting levels for some pesticides were lowered by NWQL and OGRL during the second year of the study. This change in reporting levels from 2003 to 2004 could affect the frequency-of-detection discussion because more detections may occur with the lower reporting level in the second year than in the first year. A list of all pesticides and pesticide degradates and their most common reporting levels for 2003 and 2004 are given in table 1 (at back of report).

For graphical presentation of chemical concentrations, the data were edited so that the "less than" remark code equaled the most common reporting level for that chemical during the 2-year study. All values with a remark code of "E" were unchanged in the editing process. Edits of the data and the changes in reporting levels for some chemicals biases the presentation of some of the results toward the most common reporting level.

Standard schematic boxplots were used in this report to show graphically the central tendency and distribution of concentrations for selected agricultural chemicals within each hydrologic compartment (fig. 5). Boxplots provide a visual summary of the center of the data (the median, centerline of the box), the variation or spread (interquartile range, the box height), the skewness (quartile skew, the relative size of box halves), and the presence or absence of unusual values (Helsel and Hirsch, 1992). The whiskers on the boxplots extend only to the last observation within one step (1.5 times the height of the box) beyond either end of the box (adjacent values) (fig. 5). Observations between one and two steps from the box in either direction are plotted with an X (outside values); and observations farther than two steps beyond the box are plotted with a small circle (detached values) (Helsel and Hirsch, 1992).

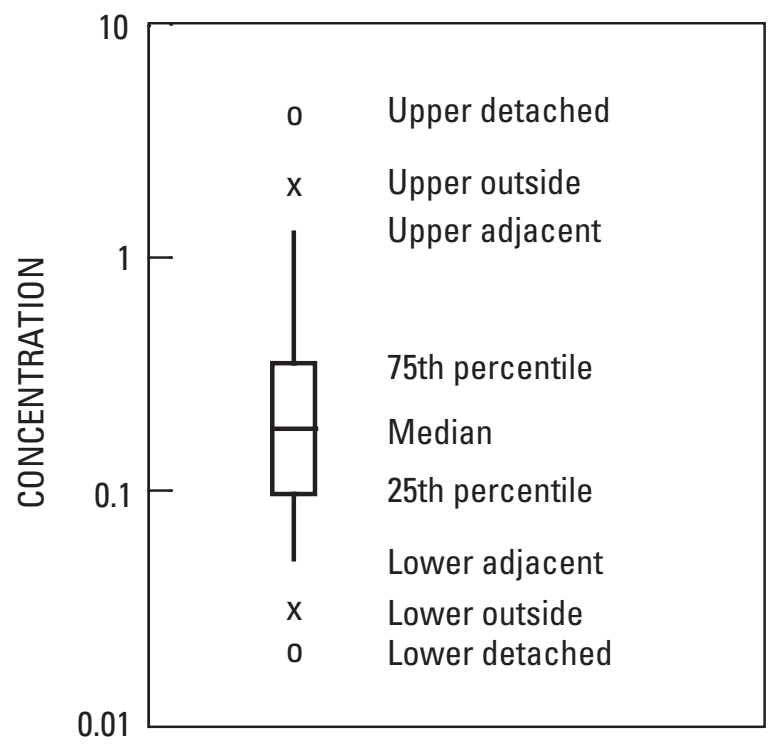

Figure 5. Example standard schematic boxplot showing central tendency and variability of waterquality concentrations.

Quality-control (QC) methods were used to evaluate the sampling bias and variability for samples collected for this study. The three QC methods used for this study are collection and analysis of field replicates, field blanks, and equipment replicates. Procedures used for collecting QC samples are explained in Mueller and others (1997) and Koterba and others (1995). Field replicates are used to assess the variability or reproducibility associated with water-quality sample collection and laboratory procedures. A large number of field-replicate QC samples are needed to determine adequately the variability in samples. Because all NAWQA sample-collection methods follow protocols and are collected in the same manner, it is more useful to analyze all of the field-replicate samples collected by all NAWQA study units across the U.S. An assessment of the variability and reproducibility of NAWQA samples is given for pesticides in Martin (2001) and for nutrients in Mueller and Titus (2005). QC methods specific to this study include field-blank and equipment-replicate samples.

Field blanks were analyzed to assess the degree of contamination introduced during field processing and handling and laboratory handling and analysis of samples. Field blanks 
were prepared by subjecting a blank solution (water known to contain none of the target analytes at quantifiable concentrations) to all aspects of sample collection, field processing, preservation, transportation, and laboratory handling and analyses that the non-QC samples (hereafter referred to as environmental samples) were subjected. A total of eight field blanks were prepared during the course of the study. Atrazine and metolachlor were detected in the blank samples but both concentrations were below the most common reporting level for the pesticides detected (fig. 6). Total nitrogen was detected in all of the blank samples, and orthophosphate was detected in 33 percent of the blank samples. Total nitrogen concentrations in blank samples were 100 times lower than average total nitrogen concentrations in environmental samples; orthophosphate concentrations in the blank samples were about 10 times lower than average orthophosphate concentrations in environmental samples (fig. 6). Calcium and magnesium ions were detected in all of the blank samples, and sodium ions were detected in 66 percent of the blank samples. Concentrations, however, were well below the average concentrations measured in the environmental samples (fig. 6).

Equipment-replicate samples were collected and analyzed to determine if the automatic sampler intake lines and bottles influenced chemical concentrations in the environmental samples. Replicates were grab samples collected simultaneously with the automatic sampler. After collection, both sets of samples were handled and processed identically. A total of 11 replicate samples were collected at the Tile Drain, Overland Flow, and Leary Weber Ditch sites during the study. Analysis of the replicate samples and the corresponding environmental samples showed that, for pesticides, there was more variability between the replicate and environmental samples at concentrations greater than $2 \mu \mathrm{g} / \mathrm{L}$ but a consistent bias was not present (fig. 7). The variability between replicate and environmental samples for nutrients and major-ion analyses was low, and a consistent bias was not present (fig. 7).

A
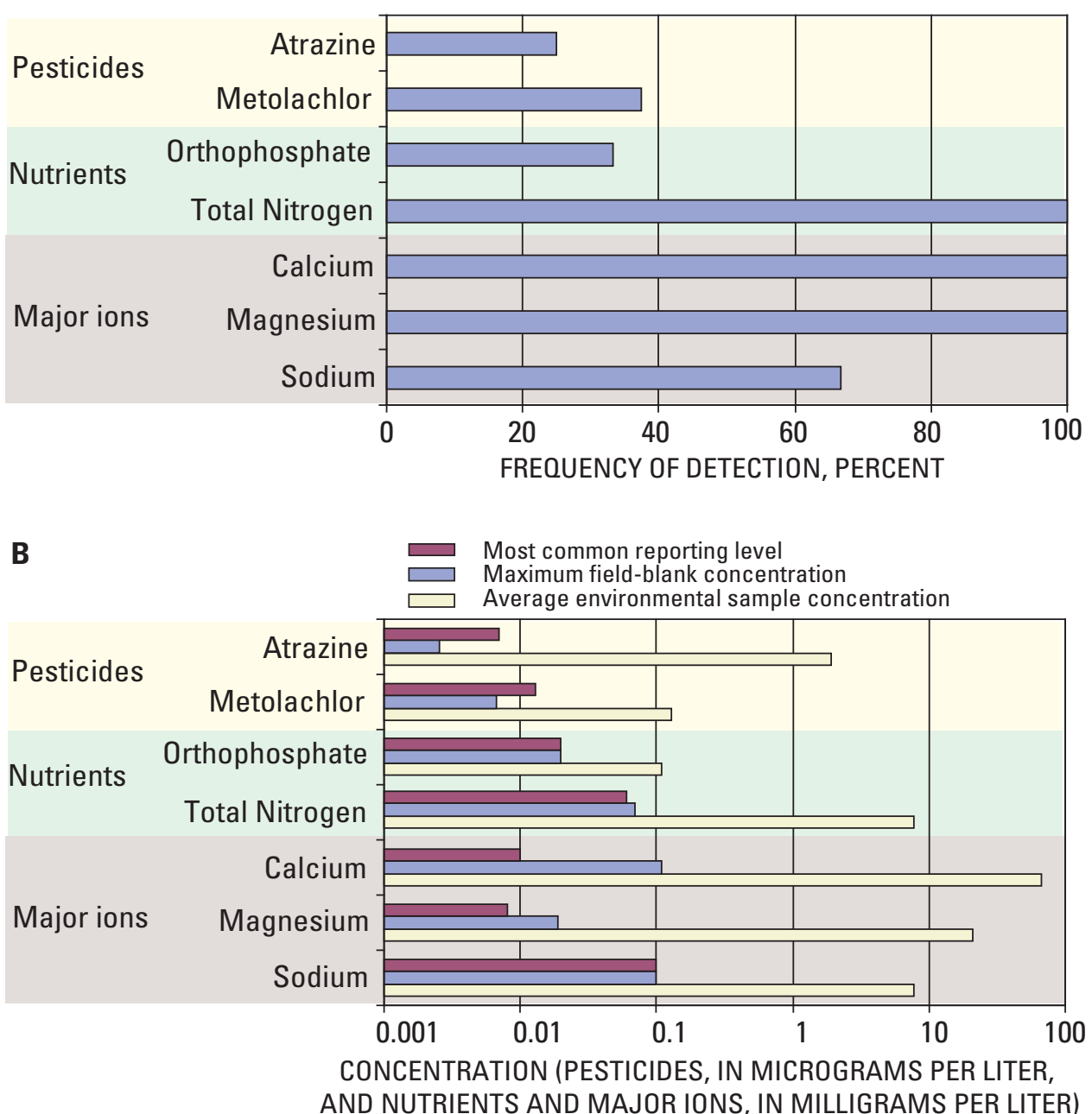

Figure 6. Quality-control results for field-blank samples for pesticides, nutrients, and major ions collected in Leary Weber Basin, Indiana, 2003-04. Graphs include only target analytes detected in field-blank samples. Graph A shows the frequency of detection in percent. Graph B shows the relation between the most common reporting level, the maximum concentration detected in the field-blank sample, and the average concentration of the target analyte for all environmental samples collected. 
A

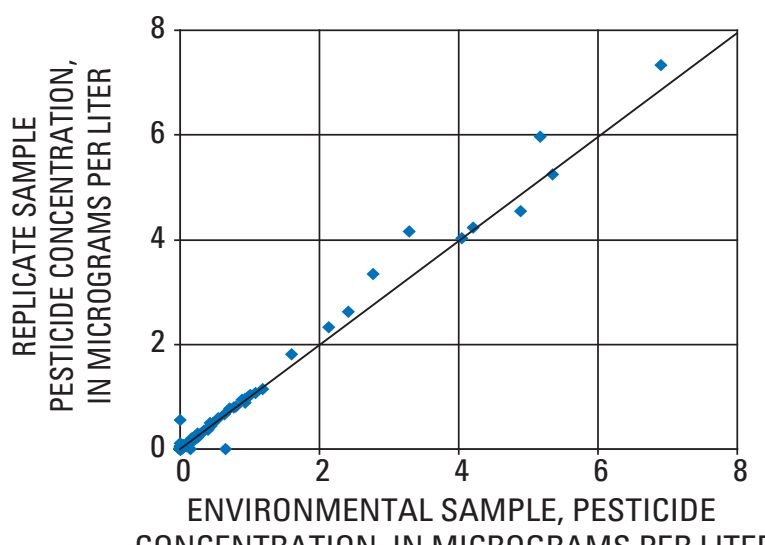

CONCENTRATION, IN MICROGRAMS PER LITER
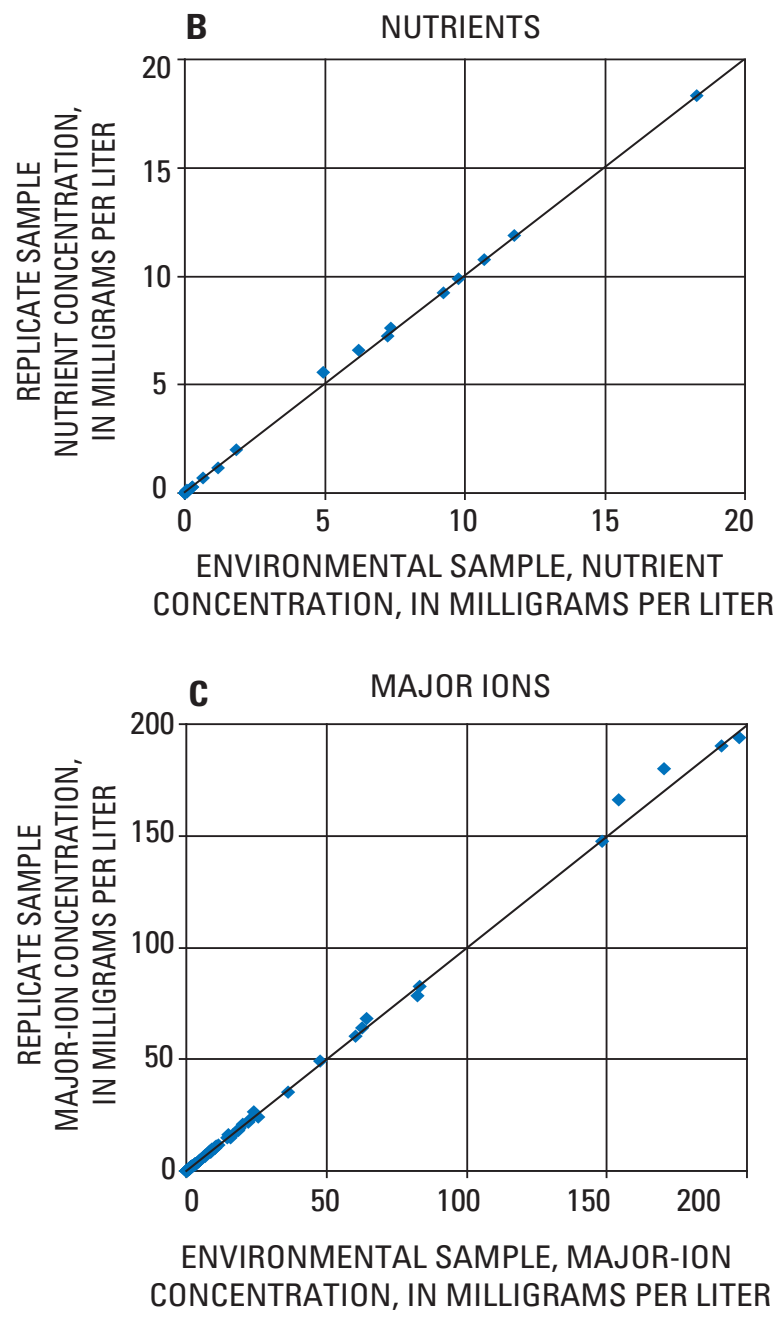

Figure 7. Quality-control results for equipment-replicate samples for (A) pesticides, (B) nutrients, and (C) major ions collected in Leary Weber Ditch Basin, Indiana, 2003-04. Replicate samples were collected by the grab method at the same time a corresponding sample was collected by the automatic sampler for Tile Drain, Overland Flow, and Leary Weber Ditch sites. Graphs include all target compounds analyzed in each group: pesticides, nutrients, and major ions.

\section{Data Analysis}

The relative contributions of water and chemicals from each of the hydrologic compartments to Leary Weber Ditch were determined through examination of ancillary data and the use of a mass-balance mixing analysis. A mass-balance mixing analysis, based on the efforts of Stone and Wilson (2006), was used to determine the overland-flow and tiledrain contributions to Leary Weber Ditch. Stone and Wilson (2006) used a two-source mass-balance mixing approach with chloride as a conservative chemical tracer to separate tile-drain flow into preferential and soil-matrix flows for storm hydrographs. The mass-balance mixing analysis can be used for more than two sources; however, the analysis requires the total chemical tracers to number one less than the total number of sources included in the analysis. Because two sources dominate flow in Leary Weber Ditch, the mass-balance mixing analysis required only one chemical tracer, which simplified the calculations.

Leary Weber Ditch potassium concentrations and flow values were used with the assumed potassium concentrations representing tile-drain and overland-flow water in the following conservation of mass equations to estimate the contributions from both sources:

$$
\begin{gathered}
Q_{l w d}=Q_{t d}+Q_{o f} \\
Q_{l w d} C_{l w d}=Q_{t d} C_{t d}+Q_{o f} C_{o f}
\end{gathered}
$$

The use of the above conservation of mass equations assumes there are no other major sources or sinks of potassium or water to Leary Weber Ditch. The terms $\mathrm{Q}_{\mathrm{lwd}}, \mathrm{Q}_{\mathrm{td}}$, and $\mathrm{Q}_{\mathrm{of}}$, represent flow from Leary Weber Ditch, tile drains, and overland flow areas, respectively. $\mathrm{C}_{\mathrm{lwd}}, \mathrm{C}_{\mathrm{td}}$, and $\mathrm{C}_{\mathrm{of}}$, represent the potassium concentrations in Leary Weber Ditch, tile-drain, and overland-flow water. The values of $\mathrm{Q}_{\mathrm{lwd}}$ were measured. The value used for $\mathrm{C}_{\mathrm{td}}$ was the median Leary Weber Ditch potassium concentration when flow was between the $50^{\text {th }}$ and $100^{\text {th }}$ percentiles, where $\mathrm{C}_{\text {of }}$ was the median of the chloride concentrations measured in overland flow. The $\mathrm{C}_{\mathrm{lwd}}$ values were linearly interpolated between the discrete samples. The computed flow values for the tile drains and overland flow then were plotted against time to produce the separated storm hydrographs.

Potassium was used as the chemical tracer because its concentrations in overland-flow water and tile-drain water were stable and different enough to evaluate mixing based on a mass-balance approach. Chloride concentrations, which Stone and Wilson (2006) used as a tracer in their mixing analysis were too variable in the tile-drain water to use as the chemical tracer for the separation of tile-drain flow and overland flow in Leary Weber Ditch. Even though potassium is not as conservative as chloride, it is a better tracer for this analysis because it does not move well through the soil profile. This results in lower amounts of potassium being present in soil water and ground water (Mallarino, 2006). Degradation of organic materials and field application of potash make potas- 
sium levels higher in overland flow than in the other hydrologic compartments; rainfall, with its lower $\mathrm{pH}$, mobilizes potassium in overland flow. The median tile-drain potassium concentration was $0.37 \mathrm{mg} / \mathrm{L}$, with a range of $0.22 \mathrm{mg} / \mathrm{L}$ to $1.03 \mathrm{mg} / \mathrm{L}$. At low flows, Leary Weber Ditch water is entirely from tile drains. Figure 8 shows potassium concentrations in Leary Weber Ditch for four selected ranges of flow duration. The median concentration of potassium in Leary Weber Ditch $(0.96 \mathrm{mg} / \mathrm{L})$, for samples collected when flow was between the 50th and 100th percentiles, was used to represent tile-drain contributions of potassium. The median overland-flow potassium concentration was $5.24 \mathrm{mg} / \mathrm{L}$, with a range of $2.39 \mathrm{mg} / \mathrm{L}$ to $9.65 \mathrm{mg} / \mathrm{L}$. The median concentration of potassium at the Overland Flow site was used to represent overland-flow contributions to Leary Weber Ditch. Stone and Wilson (2006) used a relation between specific conductance and chloride to estimate chloride concentrations throughout the tile-drain storm hydrographs; however, the analysis in this report did not have a mechanism to estimate potassium concentrations throughout the Leary Weber Ditch storm hydrographs. Linear interpolation between discrete samples on the storm hydrograph was used to estimate contributions from tile drains and overland flow.

\section{Occurrence of Agricultural Chemicals in Leary Weber Ditch Basin}

The hydrologic compartments in Leary Weber Ditch Basin are defined by chemical and physical similarities and are linked inherently, such as soil water and tile drains. For the purposes of this report, the hydrologic compartments are rain, soil water (sampled with lysimeters and wells placed within the top $9 \mathrm{ft}$ of the soils in non-aquifer materials), ground water (wells screened in the first available aquifer material [saturated sand and gravel] greater than 9 feet below land surface), tiledrain water, overland-flow water (surface runoff), and Leary Weber Ditch (the receiving stream for water flowing through or from the hydrologic compartments).

Agricultural chemicals were detected in Leary Weber Ditch and in every associated hydrologic compartment sampled during 2003 and 2004 (Baker and Lathrop, 2006). As noted previously, samples were collected from the tile-drain, overland-flow, and Leary Weber Ditch during storms, rather than at a fixed frequency throughout the 2 years. This targeted sample collection likely provided a high bias in terms of the frequency of detection of the agricultural chemicals in those

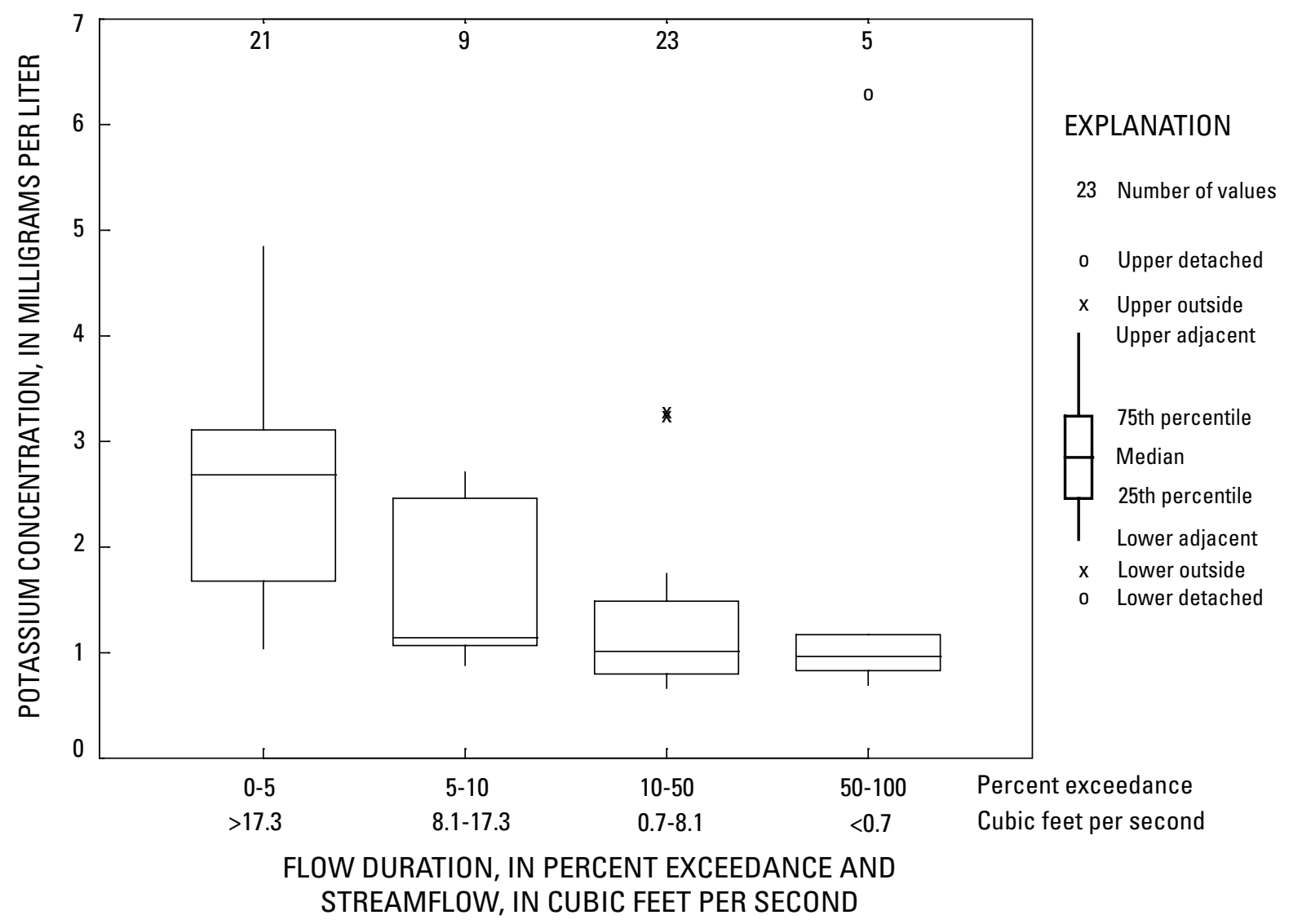

Figure 8. Distribution of potassium concentrations at selected ranges of flow duration and streamflow for U.S. Geological Survey streamflow-gaging station at Mohawk, IN (03361638). 
samples. The lowest concentrations of pesticides and nutrients were in the rain, deep lysimeter, and deep well (soil and ground water) samples. The highest concentrations of pesticides and nutrients were in the tile-drain, overland-flow, and Leary Weber Ditch samples.

\section{Rain}

Numerous pesticides were detected in rain samples, including several that were not detected in samples from Leary Weber Ditch or in any other hydrologic compartment considered in this study (Baker and Lathrop, 2006). Pesticides applied outside the basin may have volatilized or drifted through the air and, subsequently, may have been deposited in the basin through rainfall. Of the 84 pesticide parent or pesticide degradate compounds (table 1) that were evaluated, 26 were detected in rain samples (table 2, at back of report). Pesticide parent or pesticide degradate compounds in more than 75 percent of rain samples include aminomethylphosphonic acid (AMPA) (100 percent of the samples), glyphosate (91.2 percent), atrazine ( 84.6 percent), acetochlor (80.8 percent), and metolachlor (80.8 percent) (table 2, fig. 9). In 2004, AMPA was detected in every rain sample and glyphosate was detected in most rain samples. Alachlor, diazinon, malaoxon, malathion, metolachlor, pendimethalin, phosmet, prometon, and simazine were detected in rain samples (table 2, fig. 9). These compounds, however, were not applied to the fields at the study sites. In general, concentrations of pesticide parent compounds were higher than concentrations of their degradates. Atrazine and glyphosate concentrations were usually higher than their degradates in most samples from rain water (fig. 10). Atrazine and glyphosate concentrations in rain samples, although not insignificant, were generally lower than in tile-drain, overland-flow, or Leary Weber Ditch samples (fig. 10). Acetochlor and alachlor concentrations in rain samples were similar to overland-flow samples (fig. 10). Metolachlor concentrations in rain samples were similar to those in Leary Weber Ditch samples (fig. 10). The highest concentrations of all pesticides detected in rain samples occurred shortly after chemicals were applied to the fields in the spring (fig. 11). Acetochlor and chlorpyrifos concentrations often exceeded tile-drain and Leary Weber Ditch concentrations (fig 11). The highest atrazine concentration in a rain sample, $6.58 \mu \mathrm{g} / \mathrm{L}$, occurred soon after chemical application in 2003 (fig. 11).

Nutrients and major ions in rain have been studied since 1984 by the National Atmospheric Deposition Program (NADP) (National Atmospheric Deposition Program/National Trends Network, 2005) at sites in and near Indiana. Those agricultural chemicals were not included for analysis in rain samples collected for this study. Rain samples were analyzed for nutrients (nitrate only) in 2004 to provide a comparison between the NADP samples and samples collected for this study. Nitrate as $\mathrm{N}$ was detected in every rain sample collected in 2004; concentrations ranged from 0.18 to $0.48 \mathrm{mg} / \mathrm{L}$ as N (Baker and Lathrop, 2006). Concentrations of nitrate in NADP samples collected at Oxford, Ohio, (approximately $60 \mathrm{mi}$ southeast of the Leary Weber Ditch basin; fig. 1) during the same period ranged from 0.50 to $2.22 \mathrm{mg} / \mathrm{L}$ as $\mathrm{N}$ (National Atmospheric Deposition Program/National Trends Network, 2005). Nitrate concentrations in rain samples were significantly different (Wilcoxon rank-sum p-values $<0.01$ ) than those in any other hydrologic compartment. Nitrate concentrations in rain samples were higher than those in overland-flow and ground-water samples; they were approximately 10 to 20 times lower than concentrations in unsaturated soil-water, tile-drain water, and Leary Weber Ditch samples (fig. 12).

\section{Soil Water}

The soil-water hydrologic compartment was sampled with lysimeters and in wells drilled and completed in the soil to a depth of $9 \mathrm{ft}$ below land surface in predominantly silt- and clay-sized material (fig. 4). In 2003 and 2004, the water table in the soil-water hydrologic compartment frequently rose above the depths of the lysimeters and well screens (fig. 3C). This section describes results of the analyses of samples collected from lysimeters during saturated (water table above the depth of the lysimeter) and unsaturated (water table below the depth of the lysimeter) conditions. Samples collected from wells screened in the soil-water hydrologic compartment are considered to represent saturated conditions.

Discrete water samples were collected from soil water in 2004. Of the 84 pesticides analyzed, 20 were detected in soil-water samples (table 2, fig. 9). Pesticide degradates were detected more often than the pesticide parent compounds. Pesticide parent and pesticide degradate compounds with a 75-percent frequency of detection or higher were acetochlor ethanesulfunic acid (acetochlor ESA) (100 percent of samples), acetochlor oxanilic acid (acetochlor OXA) (80.4 percent), and alachlor ethanesulfunic acid (alachlor ESA) (81.2 percent) (fig. 9). The highest concentrations of alachlor ESA were detected in the soil-water hydrologic compartment in saturated and unsaturated conditions (fig. 10). For alachlor, metolachlor, and acetochlor and their degradates, the concentrations were similar for saturated and unsaturated conditions (fig. 10). Concentrations of acetochlor ESA, alachlor ESA, and metolachlor ESA were higher than the parent compounds in soil-water samples (fig. 10). Atrazine and 2-chloro-4isopropylamino-6-amino-s-triazine (deethylatrazine) were detected at higher concentrations in soil-water samples collected under saturated conditions than in samples collected under unsaturated conditions (fig. 10). Atrazine was detected in shallow lysimeters ( 2 and $3 \mathrm{ft}$ ) but not in deeper lysimeters $(4,5$, and $6 \mathrm{ft})$ (fig. 13). 

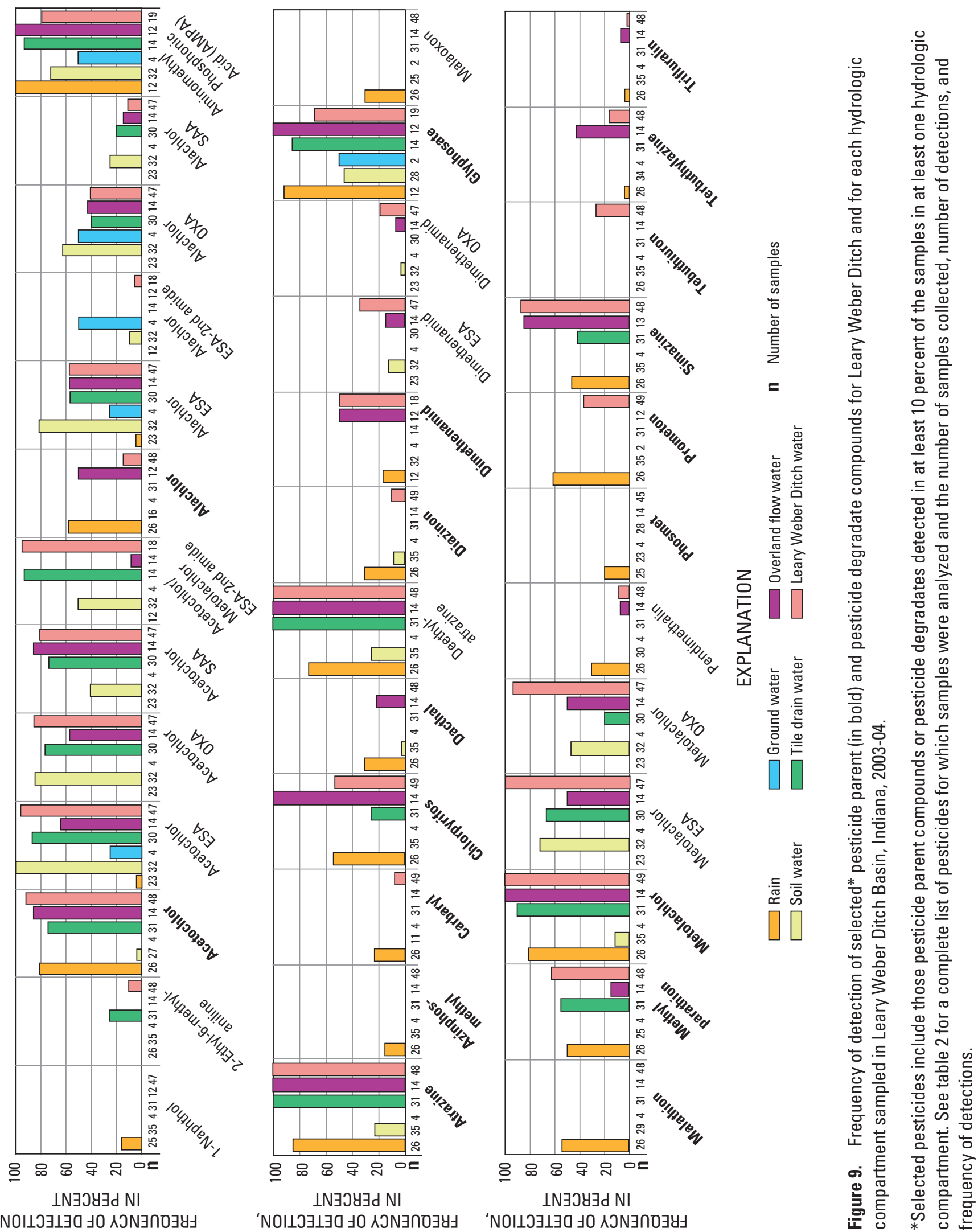


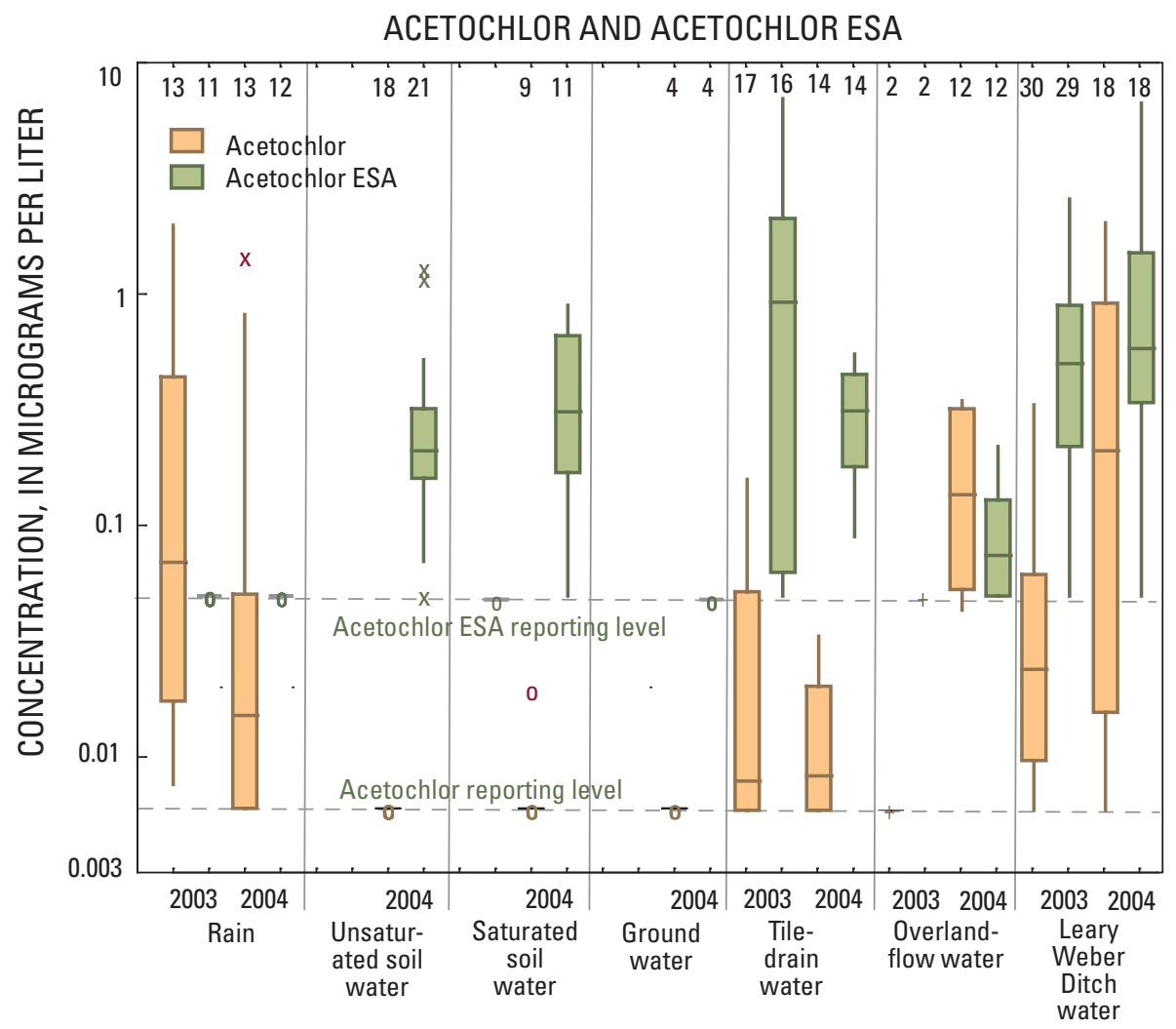

EXPLANATION

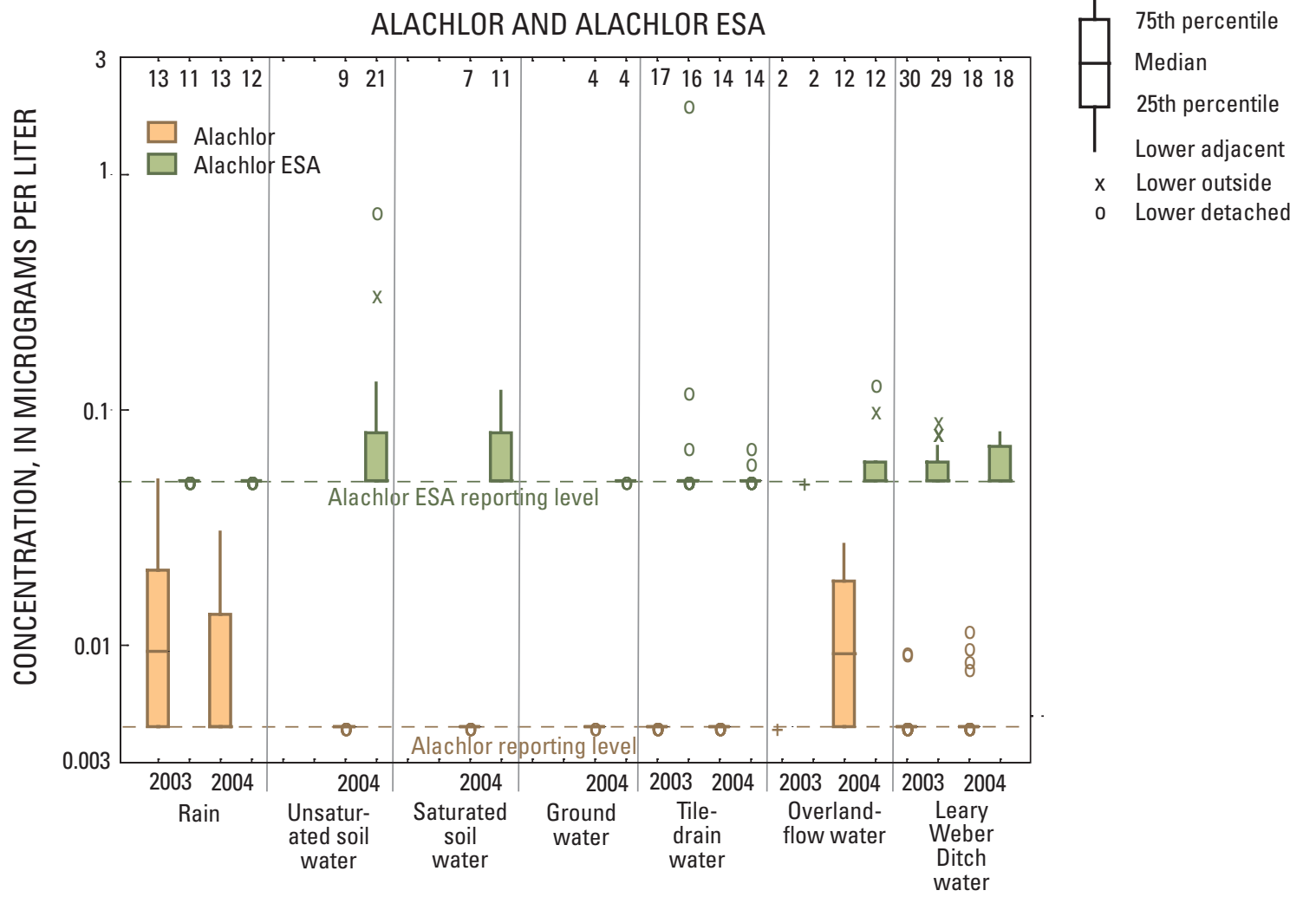

Figure 10. Distribution of concentrations of selected pesticide parent and pesticide degradate compounds in Leary Weber Ditch and in each hydrologic compartment sampled in Leary Weber Ditch Basin, Indiana, 2003-04. 
ATRAZINE AND DEETHYLATRAZINE

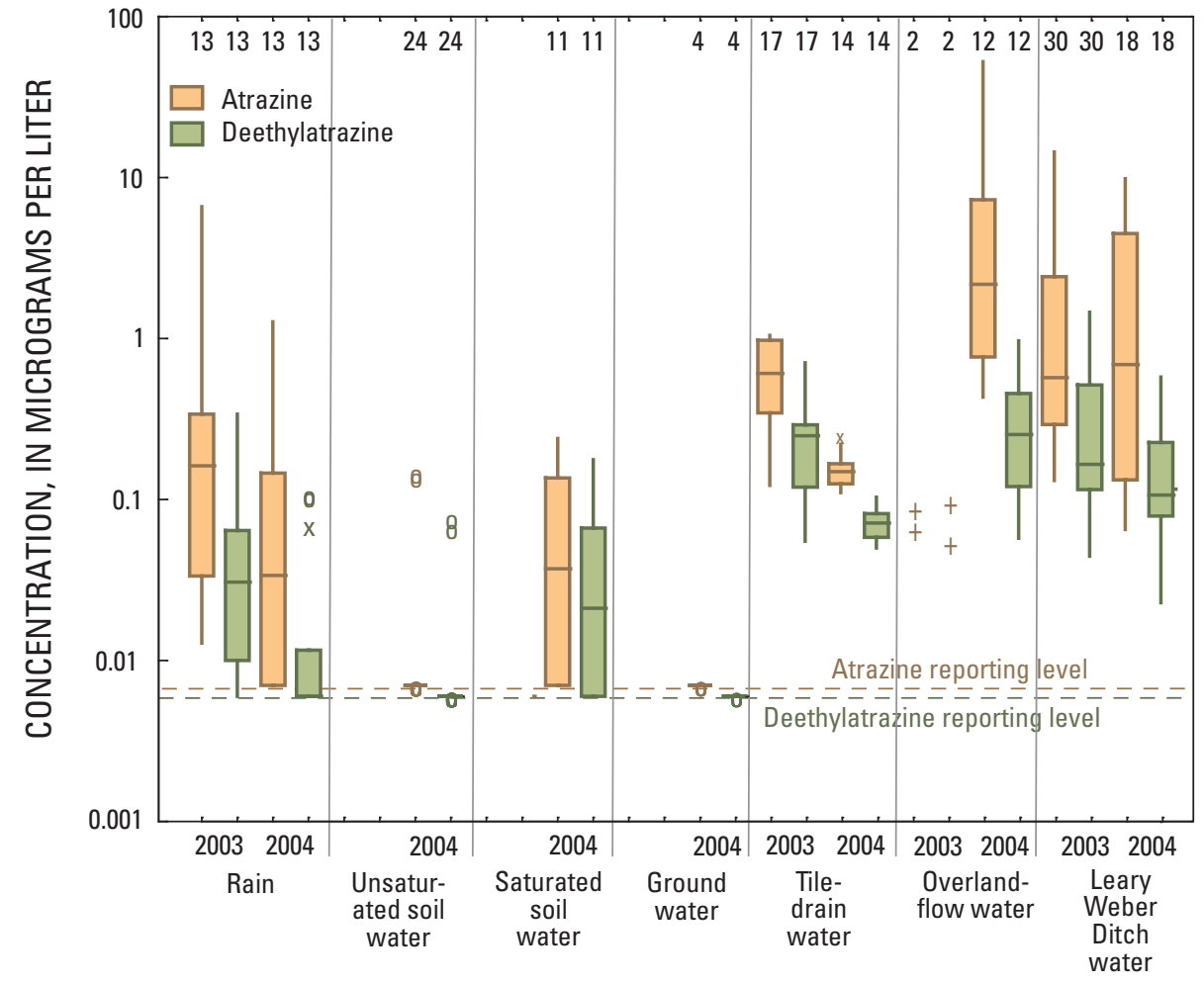

\section{EXPLANATION}

14 Number of values

o Upper detached

x Upper outside Upper adjacent

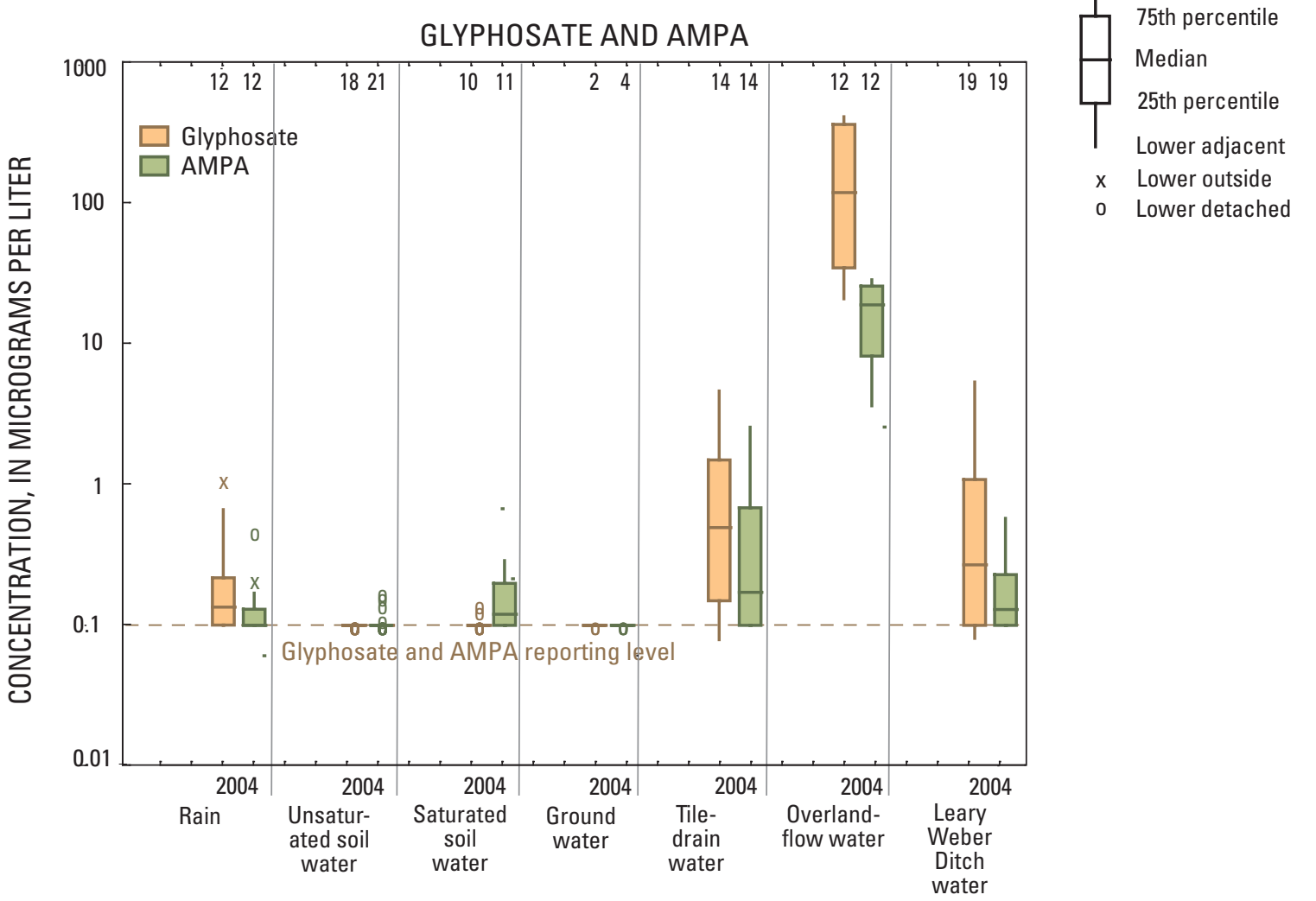

Figure 10. Distribution of concentrations of selected pesticide parent and pesticide degradate compounds in Leary Weber Ditch and in each hydrologic compartment sampled in Leary Weber Ditch Basin, Indiana, 2003-04.-Continued 


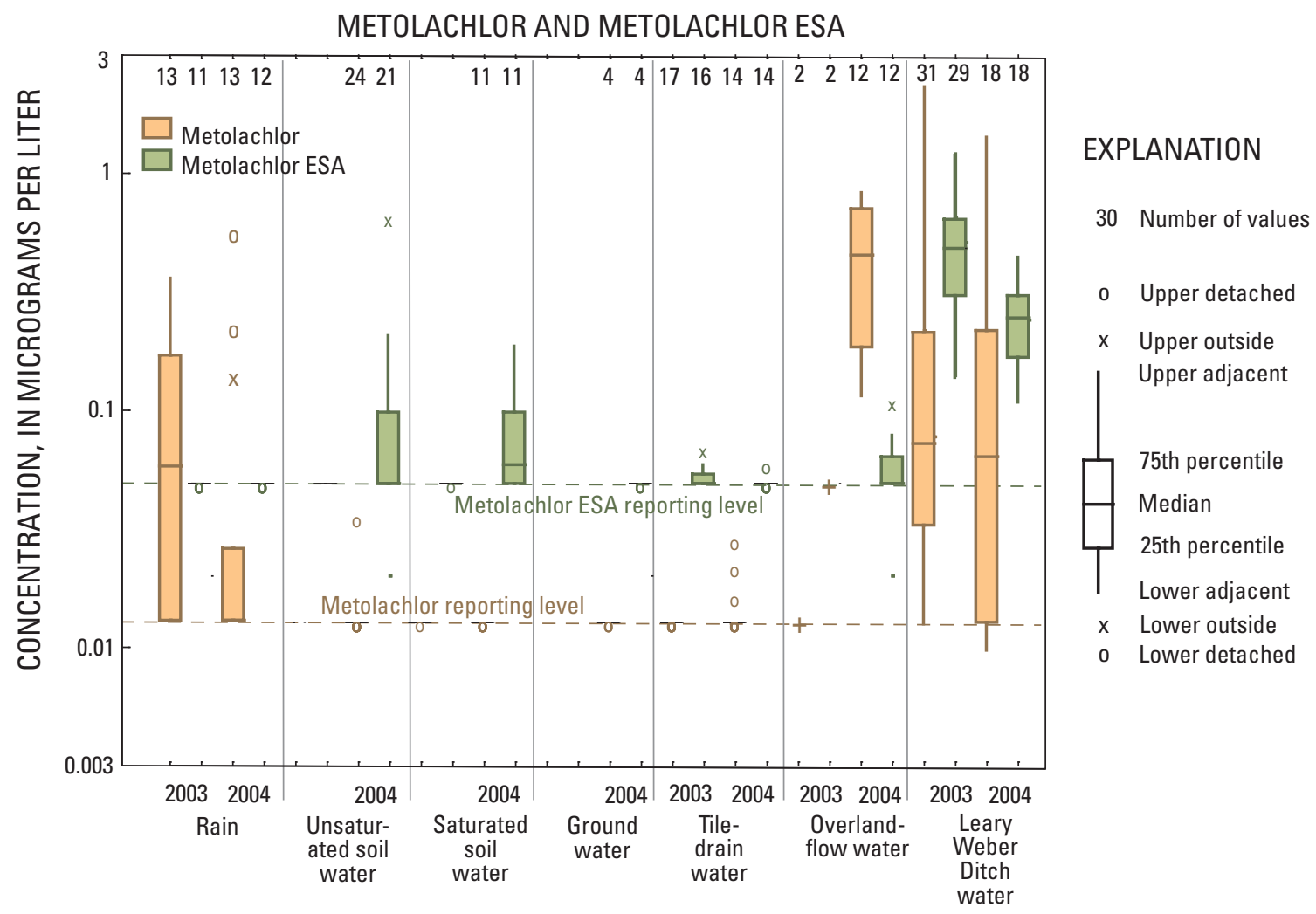

Figure 10. Distribution of concentrations of selected pesticide parent and pesticide degradate compounds in Leary Weber Ditch and in each hydrologic compartment sampled in Leary Weber Ditch Basin, Indiana, 2003-04.-Continued 

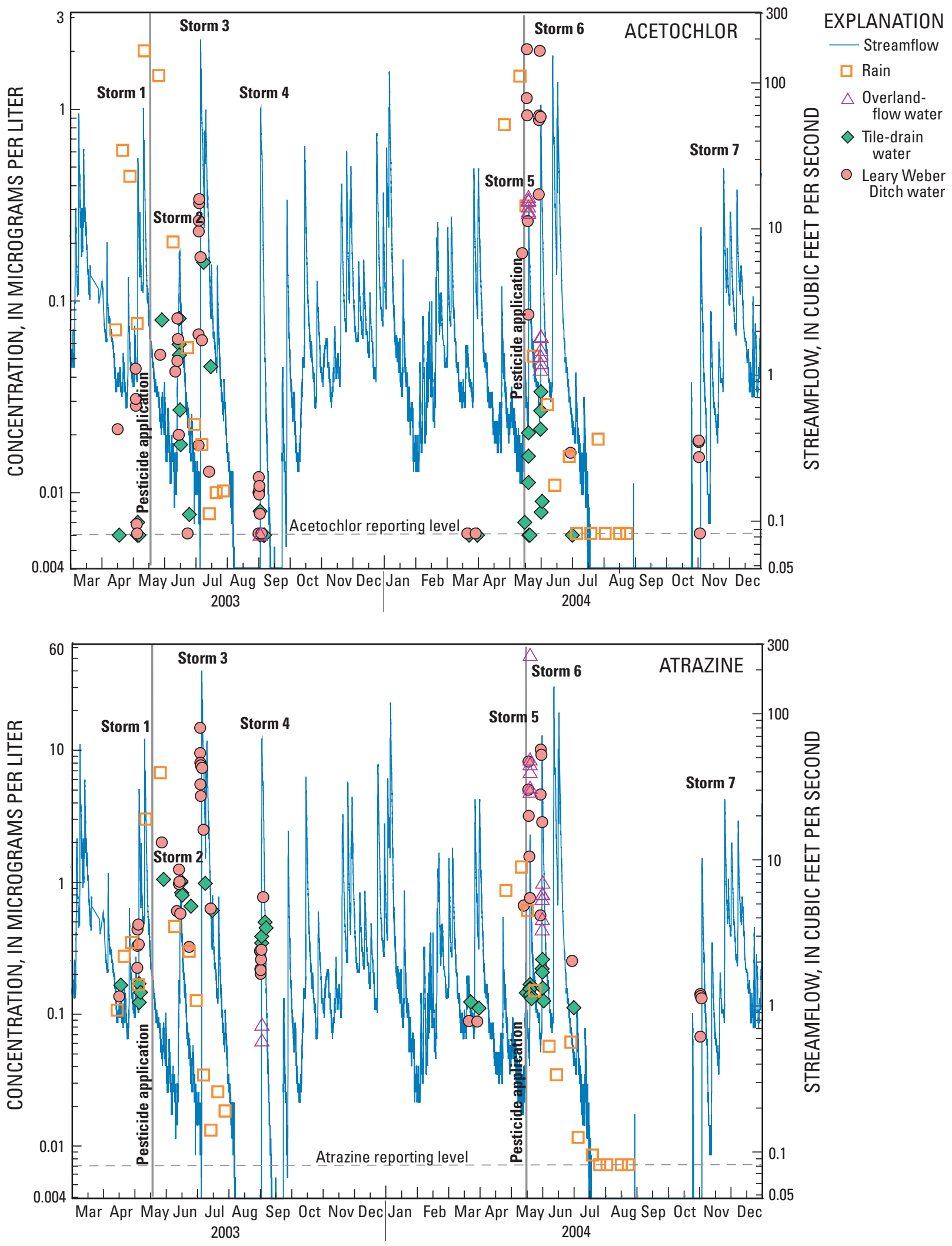

Figure 11. Relation of selected pesticide concentrations to streamflow for the hydrologic compartments sampled in Leary Weber Ditch Basin, Indiana, 2003-04. 



Figure 11. Relation of selected pesticide concentrations to streamflow for the hydrologic compartments sampled in Leary Weber Ditch Basin, Indiana, 2003-04._Continued 

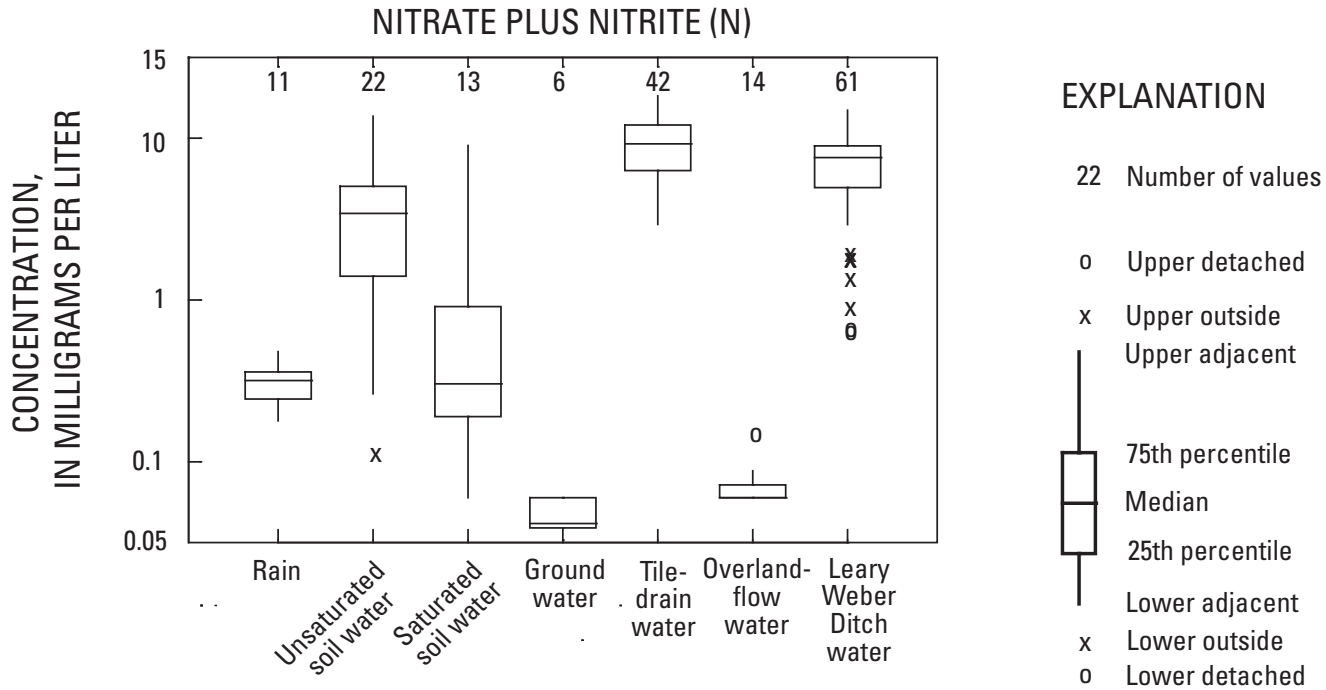

TOTAL NITROGEN
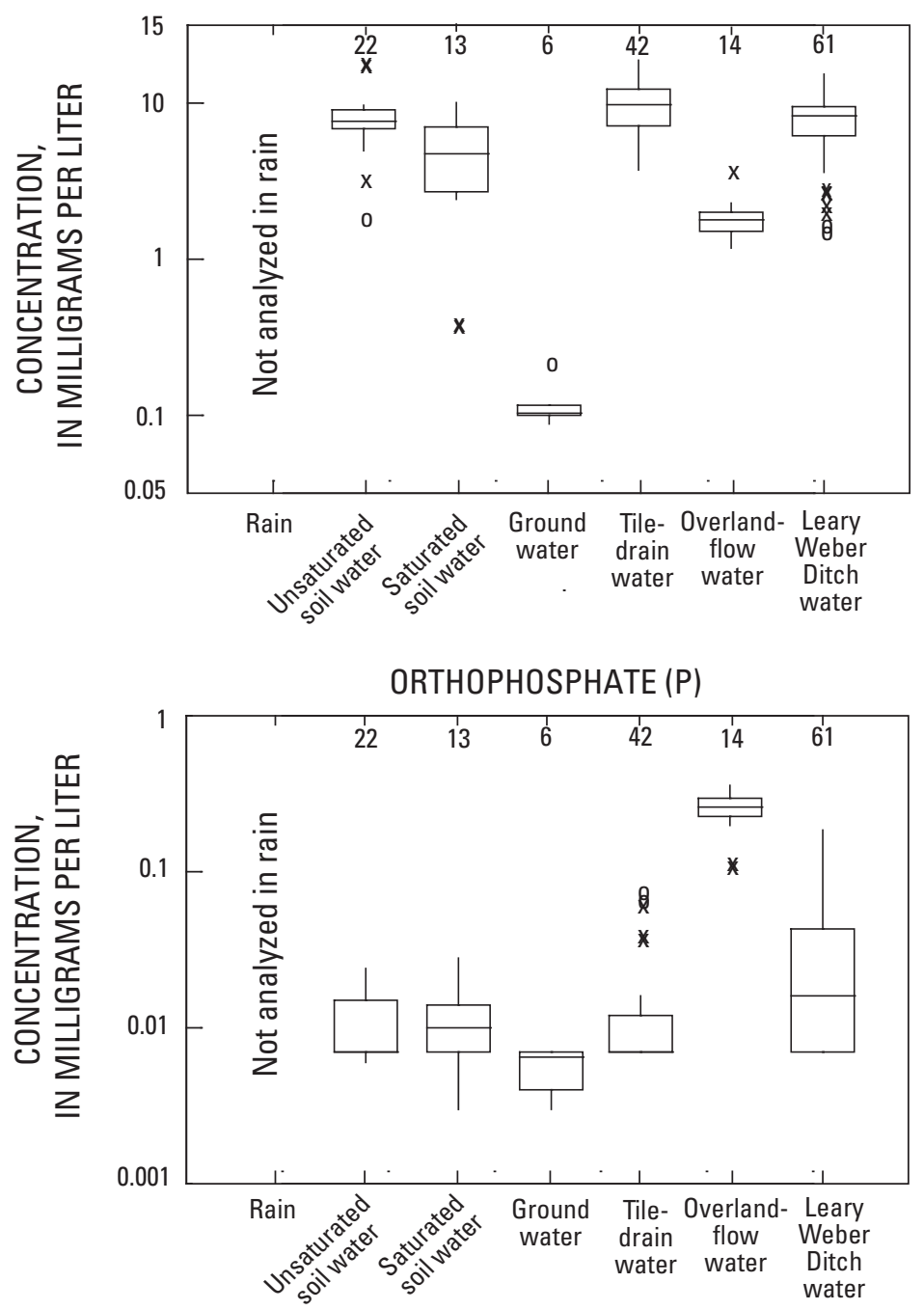

Figure 12. Distribution of nutrient concentrations in Leary Weber Ditch and in each hydrologic compartment sampled in Leary Weber Ditch Basin, Indiana, 2003-04. 

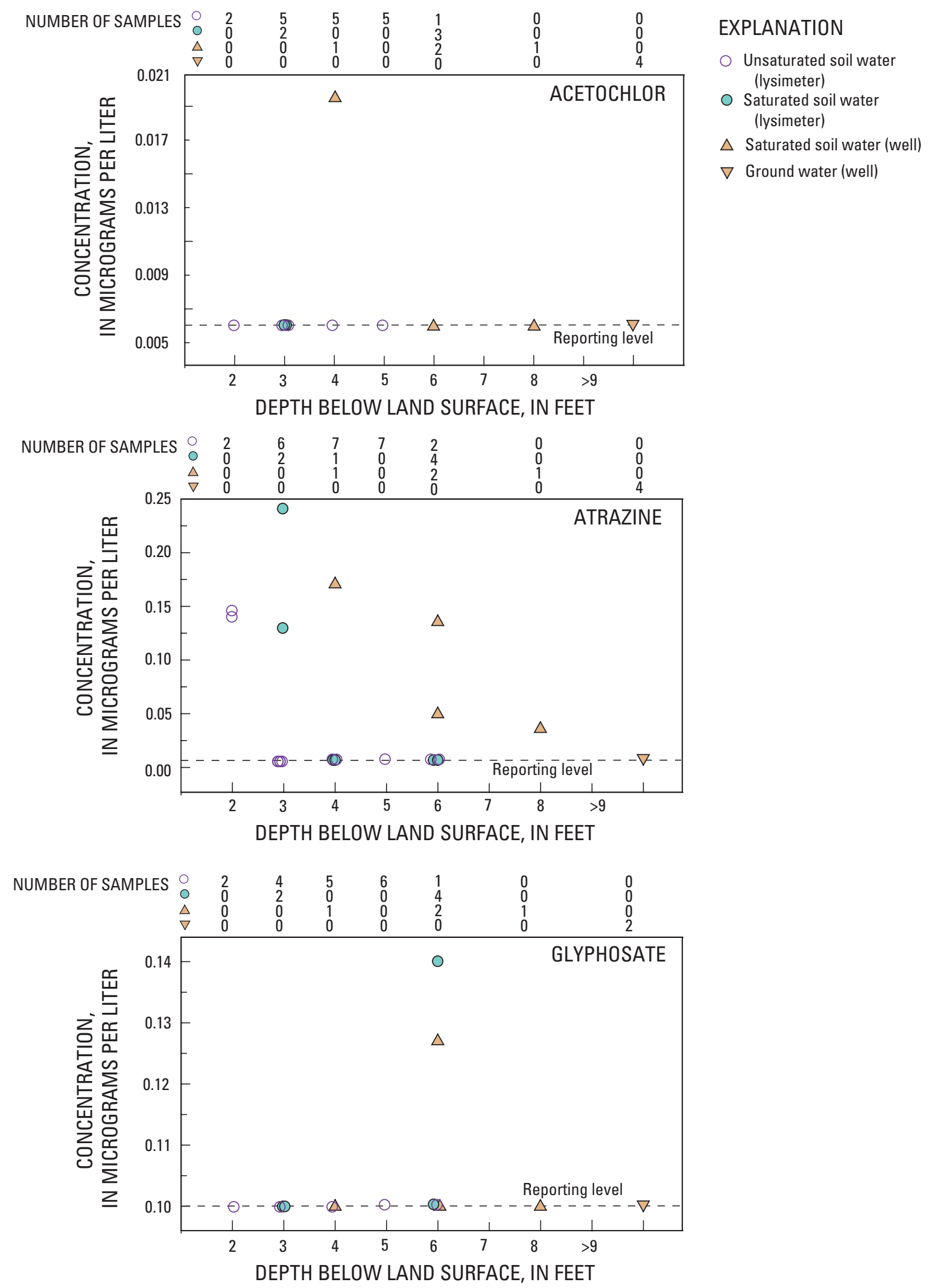

Figure 13. Concentration of selected pesticide parent and pesticide degradate compounds in lysimeter and well samples collected in the soil-water and ground-water hydrologic compartments in Leary Weber Ditch Basin, Indiana, 2004. 

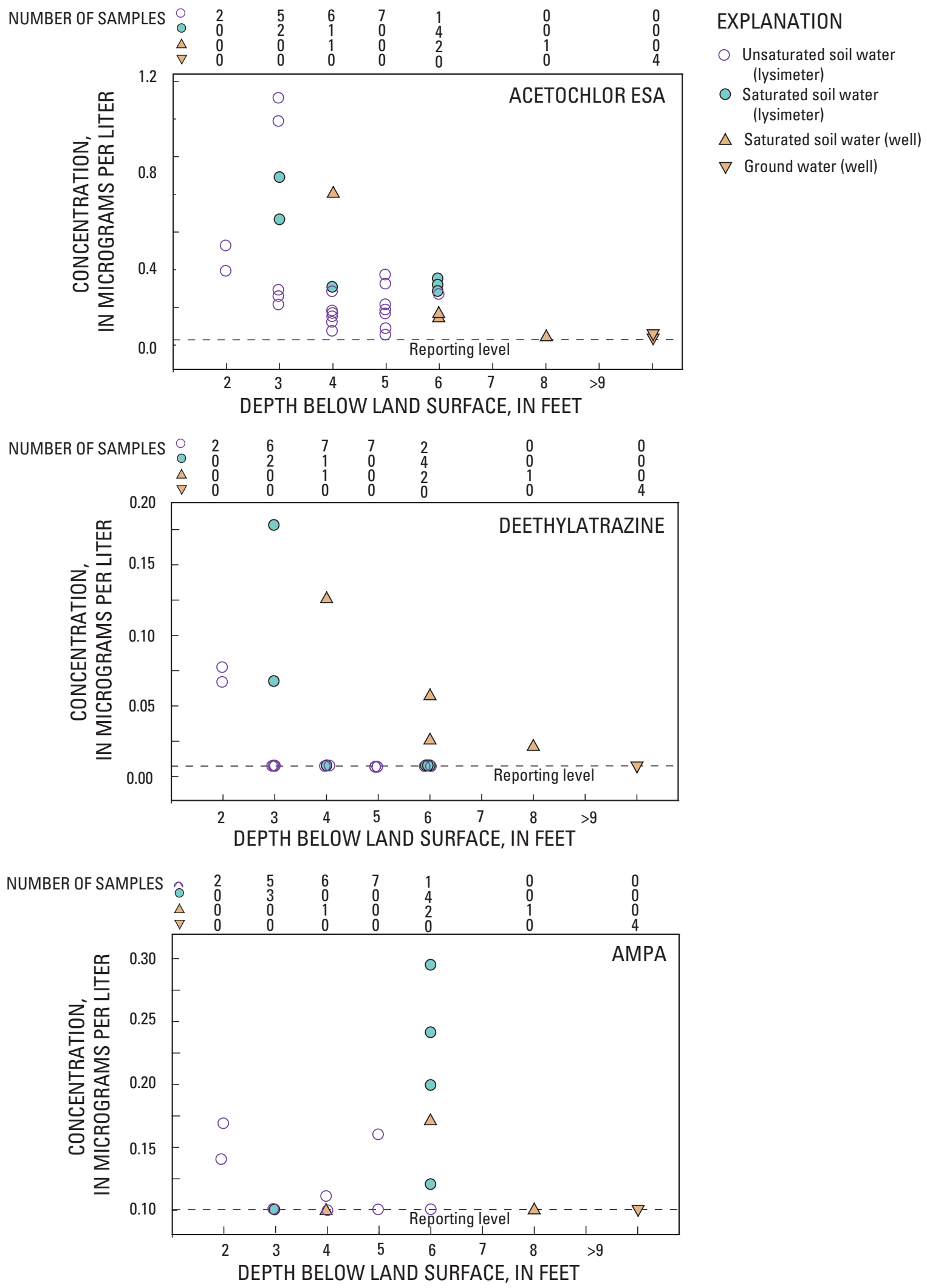

Figure 13. Concentration of selected pesticide parent and pesticide degradate compounds in lysimeter and well samples collected in the soil-water and ground-water hydrologic compartments in Leary Weber Ditch Basin, Indiana, 2004. _ Continued 
Atrazine and deethylatrazine were detected in all soil-water well samples (fig. 13). Glyphosate was detected in one sample from the deep ( $6 \mathrm{ft}$ ) lysimeter and one sample from the 6-ft-deep well at the South site under saturated conditions; it was not detected in other lysimeter or well samples (fig. 13). This presence was likely a result of the rapid transformation of glyphosate to AMPA and the strong adsorption of glyphosate on the soil matrix (Vereecken, 2005). AMPA was in the 2-, 4-, 5-, and 6-ft lysimeters under saturated and unsaturated conditions. The highest AMPA concentrations were in the 6-ft lysimeter samples from the South site under saturated conditions. The frequency and number of samples collected from the soil-water hydrologic compartment were not large enough to determine if a corresponding rise in the concentrations of pesticides in this hydrologic compartment was a result of increased amounts of rainfall.

Nitrate was detected in samples collected from nearly every lysimeter and soil-water well in 2004 (Baker and Lathrop, 2006). Nitrate concentrations in lysimeter samples collected under unsaturated conditions were significantly different (Wilcoxon rank-sum p-values < 0.01) than in samples collected under saturated conditions. Nitrate concentrations were higher in samples collected under unsaturated conditions than in those collected under saturated conditions (fig. 14). Orthophosphate concentrations were low in unsaturated and saturated soil-water samples (fig. 12). The major-ion chemistry of saturated soil-water samples showed a slightly different chemical signature than that of unsaturated soil-water samples (fig. 15A). A higher percentage of sulfate ions generally was detected in unsaturated soil-water samples than saturated soilwater samples. The concentrations of calcium, magnesium, potassium, and sulfate in saturated soil-water samples differ significantly (Wilcoxon rank-sum p-values <0.01) from the concentrations of these constituents in samples collected from Leary Weber Ditch and from the other hydrologic compartments (ground water, tile-drain water, and overland-flow water). (Rain water was not analyzed for major-ion chemistry.)

\section{Ground Water}

Discrete ground-water samples were collected from wells screened deeper than $9 \mathrm{ft}$ below land surface in 2004. Of the 84 pesticide parent and pesticide degradate compounds for which the samples were analyzed, 6 were detected in groundwater samples (table 2, fig. 9). Glyphosate was the only pesticide parent compound in the ground-water samples, and it was detected in one of two samples. Alachlor ESA-2nd amide, alachlor OXA, and AMPA were the pesticide degradates detected most frequently in ground-water samples (fig. 9).

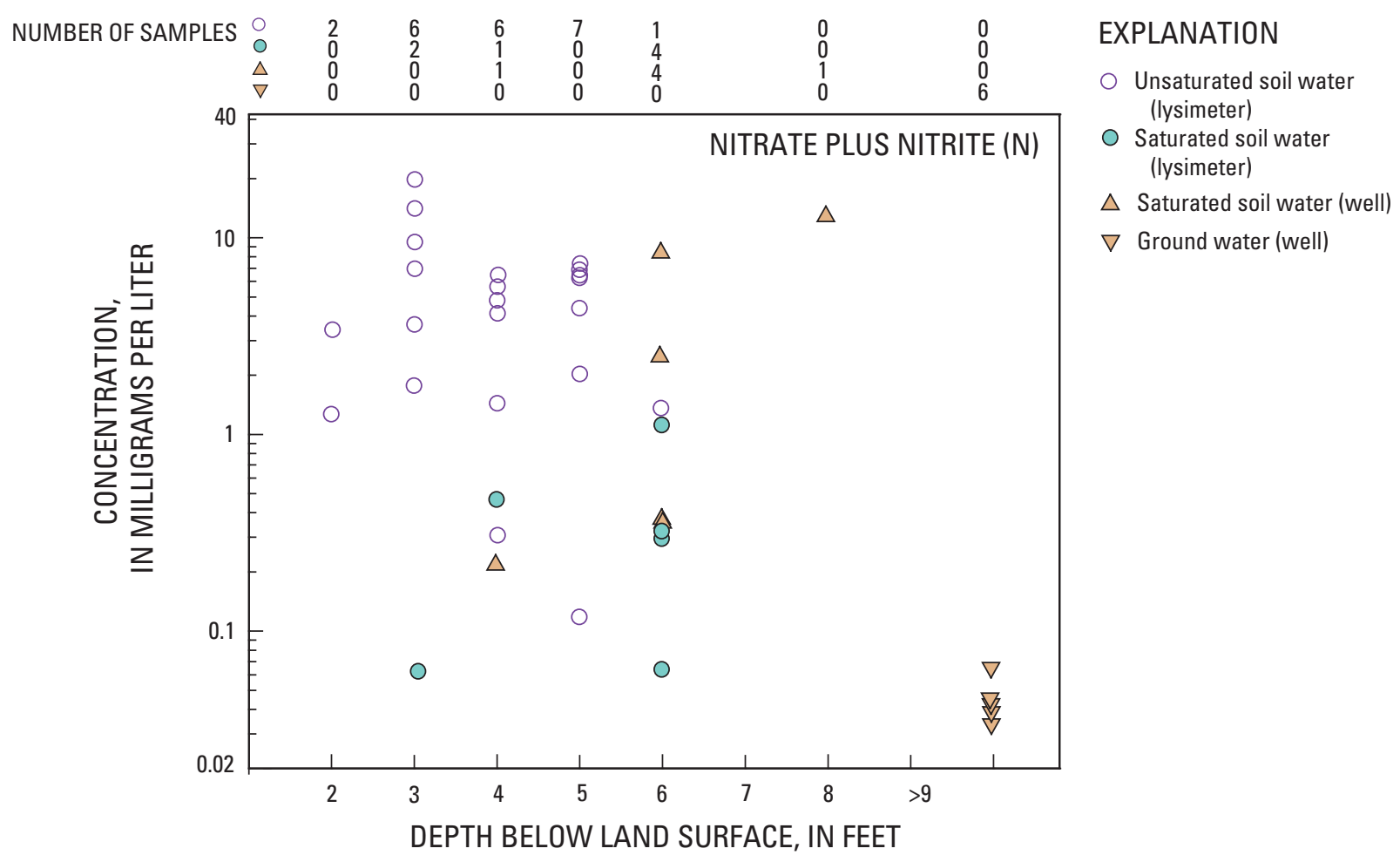

Figure 14. Concentrations of nitrate plus nitrite $(\mathrm{N})$ in lysimeter and well samples collected in the soil-water and ground-water hydrologic compartments in Leary Weber Ditch Basin, Indiana, 2004. 


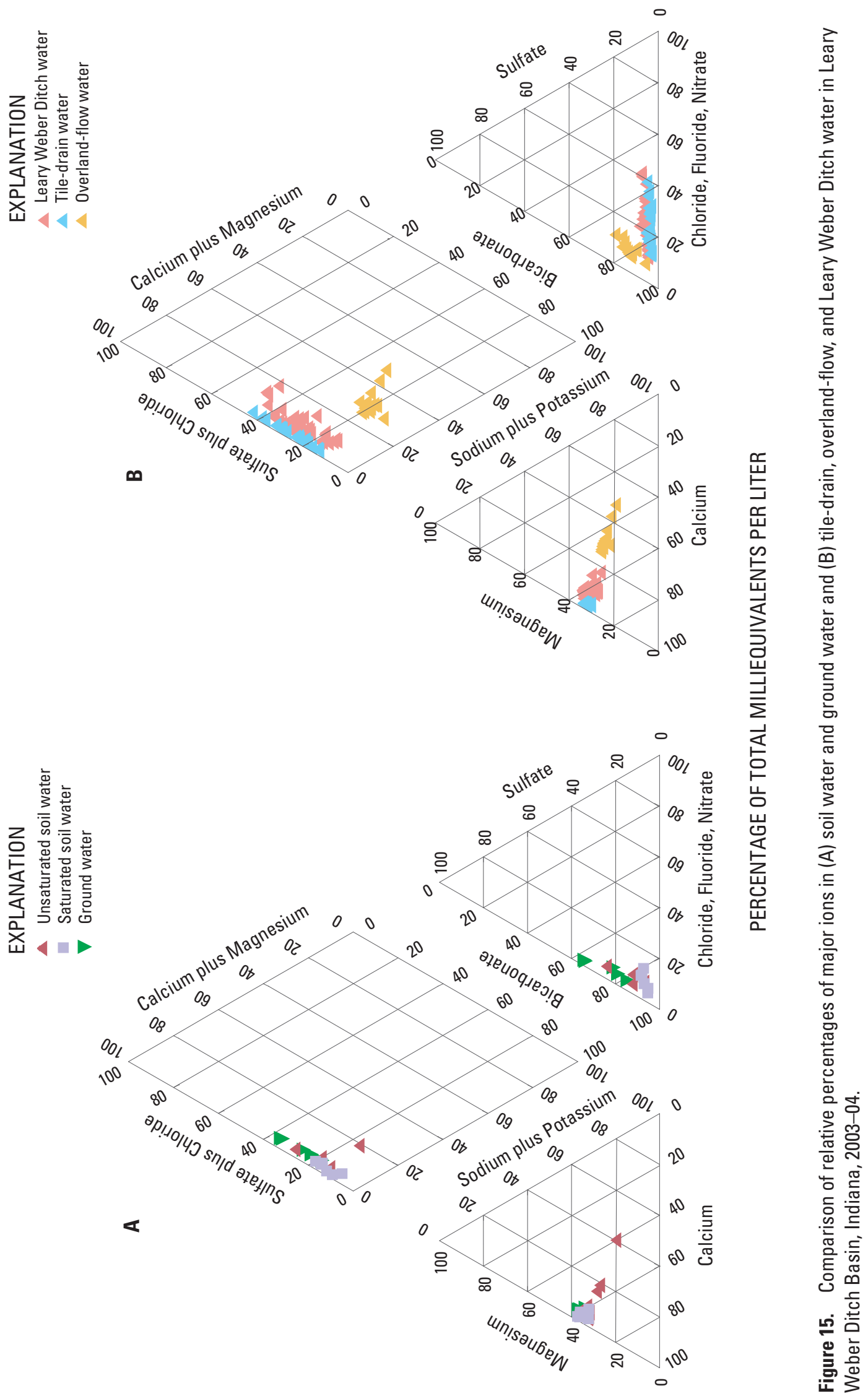


The few pesticide detections in ground-water samples (figs. 9, 10, and 13) probably can be explained by (1) the long time required for pesticides to travel from land surface to the shallow aquifers, and (2) the tile drains that divert much of the pesticides out of the soil-water hydrologic compartment before they reach ground water. Water samples were not analyzed for age, but the high silt and clay content of the soils suggests low hydraulic conductivity in the absence of macropores. Although macropores/preferential-flow paths may be present above the tile drains (Stone and Wilson, 2006), they likely do not extend much below the level of the tile drains. The soils below the tile drains more likely are saturated-and for longer periods; therefore, there should be fewer worm burrows, roots, and desiccation fractures.

Nitrate was detected in four of six ground-water samples collected in 2004 (Baker and Lathrop, 2006). Nitrate concentrations in ground-water samples were significantly different (Wilcoxon rank-sum p-values < 0.01) — and lower-than concentrations measured in Leary Weber Ditch and in the other hydrologic compartment samples, including soil water (figs. 12 and 14). Orthophosphate concentrations were significantly different (Wilcoxon rank-sum p-values $<0.01$ ) _ and lower-in ground-water samples than in the other hydrologic compartments (fig. 12). The major-ion chemistry of the ground-water samples suggests that the contact time of water with soil particles and aquifer substrate is longer than for soil water (fig 15A). Sulfate and calcium concentrations were significantly different (Wilcoxon rank-sum p-values $<0.01$ ) - and higher-for ground-water samples than for saturated-soil water samples.

\section{Tile-Drain Water}

In tile-drain samples, 20 pesticides were detected (table 2). In general, pesticide parent compounds were detected less frequently than their degradates. Pesticide parent and pesticide degradate compounds detected in more than 75 percent of the samples were atrazine (100 percent of the samples), deethylatrazine (100 percent), acetochlor/metolachlor ESA-2nd amide (92.9 percent), AMPA (92.9 percent), metolachlor (90.3 percent), acetochlor ESA (86.7 percent), glyphosate (85.7 percent) and acetochlor OXA (76.7 percent) (fig. 9). Atrazine and acetochlor were applied to the field above the tile drain in 2003, and glyphosate was applied in 2004. Glyphosate and AMPA were detected in almost every sample collected from the tile-drain in 2004 (figs. 9 and 10). Atrazine and glyphosate concentrations were usually higher than their degradates in most samples from the tile-drain (fig. 10). Concentrations of acetochlor ESA, alachlor ESA, and metolachlor ESA were higher than the parent compounds in tile-drain samples (fig. 10). The highest glyphosate concentrations $(4.7 \mu \mathrm{g} / \mathrm{L})$ were detected in samples collected near the peak tile-drain flow during storms (Stone and Wilson, 2006). Atrazine and acetochlor concentrations were higher in 2003 when these pesticides were applied with the corn crop rotation than in 2004 when they were not applied with the soybean crop rotation (fig. 10). Atrazine and acetochlor concentrations also were higher during storms after pesticide application than at other times of the year (fig. 11). Tile-drain samples were not collected during most of storm 3 because of equipment failure. Storm 3 was the first intense storm following application of atrazine to the field; therefore it is likely that the peak tiledrain atrazine concentrations for this storm would have been higher than the single sample $(0.979 \mu \mathrm{g} / \mathrm{L})$ collected during storm 3 (fig. 11). Acetochlor ESA and metolachlor ESA were detected in higher concentrations than the pesticide parent compounds (fig. 10). Neither metolachlor nor alachlor were applied to the field above the tile drain in 2003 or 2004, indicating a potential carryover from previous years of application, drift from an adjacent field, or deposition from rain.

Median nitrate concentrations in tile-drain samples were higher than in samples from any other hydrologic compartment (fig. 12). Nitrate concentrations in tile-drain samples averaged slightly more than $10 \mathrm{mg} / \mathrm{L}$ as $\mathrm{N}$ in 2003 and slightly less than $10 \mathrm{mg} / \mathrm{L}$ as $\mathrm{N}$ in 2004 (fig. 16). Trends in nitrate concentrations in tile-drain samples were similar to those in Leary Weber Ditch; however, nitrate concentrations in tiledrain samples were higher than those in Leary Weber Ditch during April and May 2003 and November and December 2004 (fig. 16). Nitrate concentrations were lower than those in Leary Weber Ditch during May and June 2004 (fig. 16). Most of the nitrogen in tile-drain samples was in the form of nitrate. Anhydrous ammonia was applied to the field above the tile drain in 2003; however, it was not applied to that field in 2004. Orthophosphate concentrations were low in tile-drain samples, compared to the overland-flow and Leary Weber Ditch samples; the median concentration in the tile-drain samples was similar to that in soil-water and ground-water samples (fig. 12). The major-ion chemistry of tile-drain samples shows a distinct chemical profile, compared to overland-flow and Leary Weber Ditch samples (fig. 15B). Tile-drain samples are primarily calcium-bicarbonate compositions, with significantly different (Wilcoxon rank-sum p-values $<0.01$ ) sodium and potassium concentrations than overland-flow and Leary Weber Ditch samples. Sodium and potassium concentrations in tile-drain samples were lower than concentrations in Leary Weber Ditch and overland-flow samples. 



Figure 16. Relation of selected nutrient concentrations to streamflow for the hydrologic compartments sampled in the Leary Weber Ditch Basin, Indiana, 2003-04. 


\section{Overland-Flow Water}

In overland-flow water, 26 pesticide parent and pesticide degradate compounds were detected (table 2, fig. 9). Compounds that were detected in more than 75 percent of overland-flow samples were AMPA (100 percent of samples), atrazine (100 percent), chlorpyrifos (100 percent), deethylatrazine (100 percent), glyphosate (100 percent), metolachlor (100 percent), acetochlor (85.7 percent), acetochlor sulfynilacetic acid (acetochlor SAA) (85.7 percent), and simazine (84.6 percent) (fig. 9). Atrazine, acetochlor, and chlorpyrifos were applied to the field at the Overland Flow site in 2003; glyphosate was the only chemical applied to the Overland Flow site field in 2004. Acetochlor, atrazine, and metolachlor were detected in higher concentrations than their degradates (fig. 10). Overland-flow and rain water were the only two hydrologic compartments where pesticide parent compounds were detected more frequently than their degradates. Atrazine and glyphosate concentrations were usually higher than their degradates in most samples from overland-flow water (fig. 10). The highest atrazine concentration detected in Leary Weber Ditch Basin was $52.3 \mu \mathrm{g} / \mathrm{L}$ at the Overland Flow site in 2004 (figs. 10 and 11). Atrazine was applied at this site in 2003 but not in 2004. Overland-flow samples, however, were not collected in 2003 until more than 3 months after atrazine application. Alachlor was detected in overland-flow samples during storm 5 (May 2004) even though it had not been applied to the contributing field during the 2004 season. It also was detected in rain samples indicating that rain may be the source of alachlor in overlandflow samples in 2004 (fig. 17).
Nitrate concentrations in overland-flow samples were significantly different (Wilcoxon rank-sum p-values $<0.01$ ) than concentrations measured in either rain-water, soil-water, tiledrain water, or Leary Weber Ditch samples. Nitrate concentrations in overland-flow samples were lower than concentrations in rain-water, soil-water, tile-drain water, or Leary Weber Ditch samples (fig. 12). Anhydrous ammonia was applied to the Overland Flow site in 2003 but was injected below the surface and was not available for transport in surface runoff; therefore, nitrate concentrations remained low in overlandflow water (fig. 16). Orthophosphate concentrations were higher in overland-flow samples than in Leary Weber Ditch or any other hydrologic compartment (fig. 12). The major-ion chemistry of overland-flow samples shows a different chemical signature than tile-drain and Leary Weber Ditch samples (fig. 15B). Overland-flow samples reflect the brief contact time of the water with the soils, as compared to tile-drain and Leary Weber Ditch samples.

\section{Leary Weber Ditch}

In Leary Weber Ditch, 34 pesticide parent and pesticide degradate compounds were detected (table 2, fig. 9). Atrazine, deethylatrazine, metolachlor, and metolachlor ESA, were detected in every Leary Weber Ditch sample (fig. 9). Tebuthiuron, a broad-spectrum herbicide for non-cropland application, such as clearing roadsides and rights of way, was detected in the ditch water but not in any other hydrologic compartment. Atrazine and glyphosate concentrations were higher than their degradates; however, acetochlor, alachlor, and metolachlor

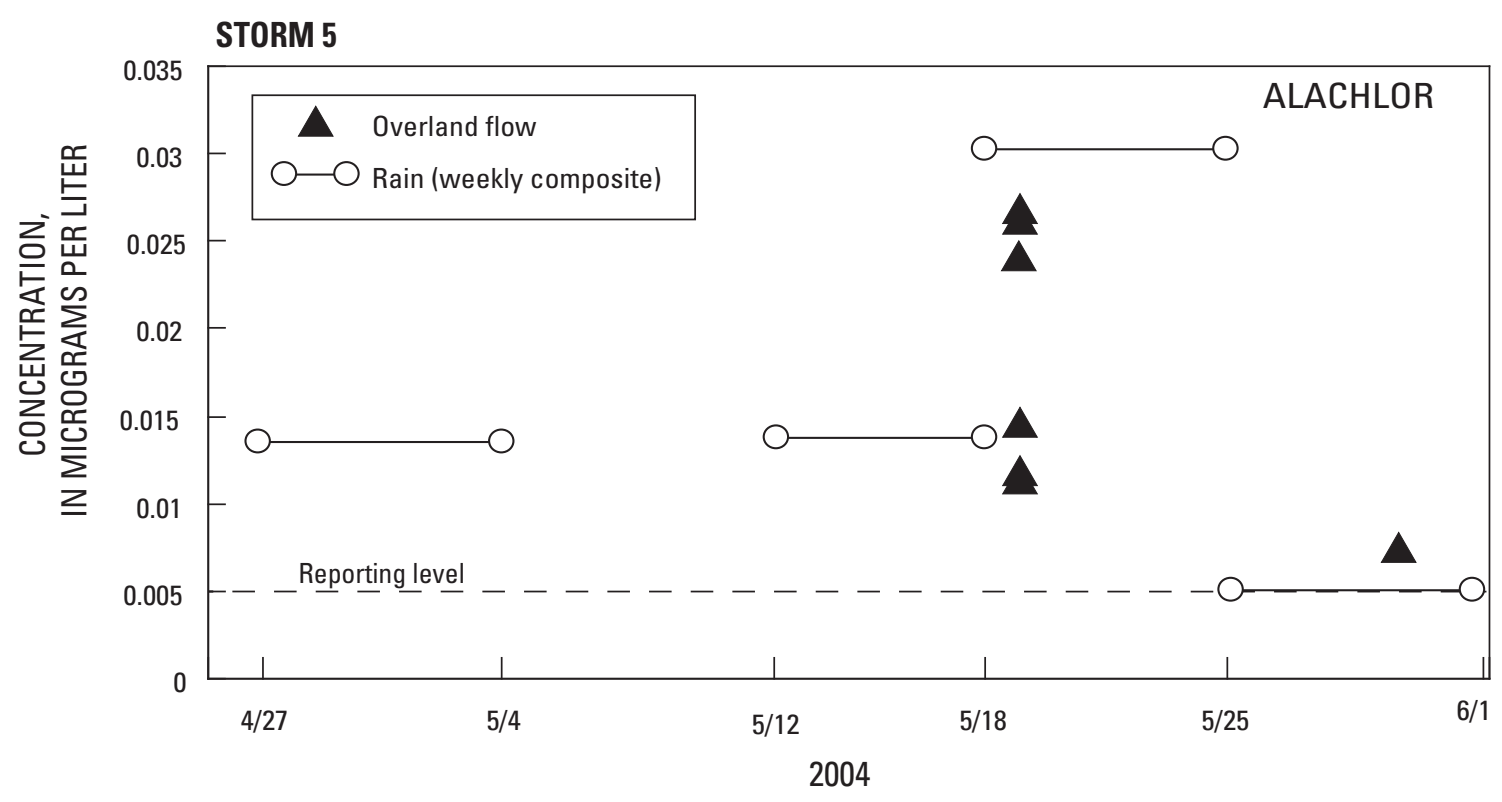

Figure 17. Comparison of alachlor concentrations measured in rain and overland-flow water during storm 5 in Leary Weber Ditch Basin, Indiana, 2004. 
concentrations were lower than their degradates (fig. 10). For atrazine, these concentrations were likely a result of its greater persistence in the environment than acetochlor, alachlor, or metolachlor (Boxall and others, 2004; Kalkhoff and others, 2003). It is possible that glyphosate concentrations were higher than AMPA concentrations for most Leary Weber Ditch samples because glyphosate often is used to control weeds on fields as well as fence-row weed control and other noncropped field areas throughout the growing season (Battaglin and others, 2005). Glyphosate also tends to persist in the soil and is mobilized during rainfall in overland flow or preferential flow to tile drains and consequently into Leary Weber Ditch. The highest pesticide concentrations in Leary Weber Ditch samples coincide with high streamflow after pesticide application (fig. 11).

Nitrate concentrations in Leary Weber Ditch samples were similar to those in tile-drain samples (fig. 12). Seasonal trends in the Leary Weber Ditch samples showed that nitrate concentrations were higher during May, June, November, and December 2004, with the highest concentrations in April 2003 and May and June of both years (with the exception of one sample in July) (fig. 16). Lower nitrate concentrations were detected in August and September 2003. Leary Weber Ditch was not sampled in January, February, or October of both years. For most months, the concentrations of nitrate are stable through various rates of flow; however, in samples collected in May (both years) nitrate concentrations were higher when flows were higher. This difference is likely a result of the application of nitrogen fertilizer during May, which increases the available nitrogen pool for transport. Most of the nitrogen in Leary Weber Ditch water is from nitrate. Orthophosphate concentrations in Leary Weber Ditch samples were significantly different (Wilcoxon rank-sum p-values <0.01) from concentrations in tile-drain, ground-water, and overland-flow water samples. Orthophosphate concentrations in Leary Weber Ditch samples were higher than those detected in tile-drain water and ground-water samples and lower than concentrations detected in overland-flow water samples (fig. 12). Majorion chemistry of Leary Weber Ditch samples falls between the two primary sources of water to the ditch, tile drains and overland flow (fig. 15B).

\section{Transport of Agricultural Chemicals in Leary Weber Ditch Basin}

Rain water, overland-flow water, soil water, tile-drain water, and ground water are the major hydrologic compartments that potentially contribute water and agricultural chemicals to Leary Weber Ditch. On the basis of the concentrations of chemicals present within each hydrologic compartment, it is possible to infer transport routes of these chemicals into Leary Weber Ditch. The length of time water stays in each compartment and the number of possible sources contributing water to Leary Weber Ditch ultimately influence the chemical com- position of the stream water. Chemicals may be transported quickly from the land surface in overland flow; they may volatilize, accumulate, or degrade; or they may adsorb onto soil particles as they travel through the soils into tile drains or into ground water.

Direct rainfall or air deposition of particulate matter is not an important source of water or chemicals to ditch. The surface area of the Leary Weber Ditch channel is only about 0.1 percent of the total area of the basin; therefore, the volume of rain falling directly on the channel is small relative to the volume of rain that falls throughout the basin. Median concentrations of pesticides in rain samples were lower than median concentrations in Leary Weber Ditch, tile-drain, and overlandflow samples (fig. 10). Exceptions to this are the concentrations in rain and overland-flow samples of chemicals that were not applied to the overland-flow field. Alachlor was detected in rain and overland-flow samples during storm 5 (May 2004), even though alachlor was not applied to the overland-flow field in 2003 or 2004 (fig. 17). The higher alachlor concentration in overland-flow samples from storm 5, compared to concentrations for the other storms, appears to be a direct result of higher alachlor concentrations in the rain during storm 5 (fig. 17).

Just as the rain and overland-flow compartments are linked, so too are the soil-water and tile-drain water compartments (tile drains discharge soil water to Leary Weber Ditch). As mentioned earlier in this report, the soil-water hydrologic compartment resembles the tile-drain compartment in terms of major-ion chemistry (fig. 15). In terms of water and chemical transport to Leary Weber Ditch, the contributions from the soil-water compartment are included in the discussion of tiledrain contributions.

Ground-water discharge is not a significant source of flow or chemicals to Leary Weber Ditch. The ditch is ephemeral and does not receive ground-water discharge during sustained dry periods. Field reconnaissance shows that the ditch stops flowing when the tile drains stop flowing, indicating that the tile drains are the primary source of water in the ditch between storms. Upstream from the gaging station on Leary Weber Ditch, the channel bottom is primarily fine-textured soils and clays for most of its length (U.S. Department of Agriculture, 1978). This type of material limits the ground-water to surface-water exchange, thereby limiting contributions of ground water to the channel. The farm fields also are underlain by fine-textured soils. The absence of well-defined layers of coarse-grained sediments in the shallow subsurface (between land surface and the bottom of Leary Weber Ditch) decreases the potential for lateral flow of soil water and ground water to the ditch. The lateral movement of water through soils is short-circuited by soil water discharging to the ditch through tile drains. Also, the tile drains lower the shallow water table, reducing the hydraulic gradient needed to discharge ground water to the ditch. Chemically, the ionic composition of water in wells deeper than $9 \mathrm{ft}$ is different than water in the shallow wells, water in tile drains, and the water in Leary Weber Ditch (fig. 15). On the basis of (1) the lack of a sustained base 
flow in Leary Weber Ditch, (2) the fine-grained materials that limit ground-water and surface-water interaction, and (3) the differences between ionic composition in ground water, tiledrain water, and Leary Weber Ditch water, ground water is not considered to be a significant source of water and agricultural chemicals to Leary Weber Ditch.

Overland flow and tile drains contribute most of the water and chemicals to Leary Weber Ditch. During storms, overland flow and tile drains contribute water to the ditch. Between storms, tile drains flow until all of the available water in the soils above the tile drains is removed. The amount of water that passes the Leary Weber Ditch gaging station as a result of a storm represents from 13 to 54 percent of the total volume of rain that falls in the basin during the storm (table 3 ). On an annual basis, however, the total rainfall is nearly balanced by the amount of water flowing through Leary Weber Ditch and that lost to evapotranspiration. Therefore, most of the rainfall from a storm (46 to 87 percent) is stored in the soil-water hydrologic compartment until it is lost through tile drainage, evapotranspiration, or recharge to ground water.

\section{Mixing Analysis}

A conservative mixing analysis based on potassium as a tracer was used to determine the relative contributions of overland flow and tile drains to Leary Weber Ditch during seven storms in 2003 and 2004 (fig. 18). Water in Leary Weber Ditch and in the tile-drain and overland-flow hydrologic compartments each have different chemical signatures (fig. 15). Overland-flow water has a short contact time with surficial soils before it flows into Leary Weber Ditch; therefore this water has relatively low ionic concentrations and its chemistry closely resembles that of rain. The contact time for tile-drain water with soils is longer than that of overland flow as it travels through the soil-water hydrologic compartment and is then routed through the tile drains to the ditch. Comparison of the ion chemistry in the samples of tile-drain, overland-flow, and Leary Weber Ditch water collected during 2003 and 2004 shows that the major-ion chemistry of the Leary Weber Ditch samples were between those of the tile-drain and overlandflow samples (fig. 15) and is consistent with the theory that Leary Weber Ditch water is a combination of water from the tile-drain and overland-flow hydrologic compartments.

When the maximum rainfall intensity was $0.5 \mathrm{in} / \mathrm{hr}$ or lower, overland flow contributed less than 10 percent of the Leary Weber Ditch stormflow and tile drains contributed more than 90 percent of that flow (storms 1, 2, 5, and 7) (fig. 18). The infiltration capacity of the soils was exceeded only slightly during these storms because of the light rainfall intensity and the antecedent (pre-storm) soil-moisture conditions. When the maximum rainfall intensity was $0.75 \mathrm{in} / \mathrm{hr}$ or greater, the overland-flow contribution was around 40 percent and the tile-drain contribution was around 60 percent of the total flow in Leary Weber Ditch (storms 3, 4, and 6) (fig. 18). During these storms, the soil-infiltration capacity was exceeded by rainfall intensity and near capacity antecedent soil moisture conditions. The mixing analysis shows that overland flow is an important contributor of water to Leary Weber Ditch during periods of high-intensity rainfall and when antecedent soil-moisture conditions decrease soil-infiltration capacity. At other times, however, tile drains are assumed to be the primary contributor of water to Leary Weber Ditch. This understanding of which hydrologic compartments contribute water to Leary Weber Ditch during different levels of rainfall and streamflow facilitates the investigation of chemical transport.

Table 3. Comparison of rain volume for Leary Weber Ditch Basin and streamflow at U.S. Geological Survey streamflow-gaging station at Mohawk, IN (03361638) for selected storms, 2003-04.

[in., inch; ft, foot; $\mathrm{ft}^{3}$, cubic foot; gage, USGS streamflow-gaging station]

\begin{tabular}{|c|c|c|c|c|c|}
\hline Storm & $\begin{array}{l}\text { Total rainfall } \\
\text { during storm } \\
\text { (in.) }\end{array}$ & $\begin{array}{l}\text { Total rainfall } \\
\text { during storm } \\
\text { (ft) }\end{array}$ & $\begin{array}{l}\text { Total rainfall } \\
\text { over entire basin } \\
\text { during storm } \\
\text { (thousand } \mathrm{ft}^{3} \text { ) }\end{array}$ & $\begin{array}{l}\text { Total streamflow } \\
\text { past the gage } \\
\text { during storm } \\
\text { (thousand } \mathrm{ft}^{3} \text { ) }\end{array}$ & $\begin{array}{c}\text { Percent } \\
\text { of rainfall } \\
\text { flowing past } \\
\text { the gage } \\
\text { during storm }\end{array}$ \\
\hline 1 & 1.26 & 0.1053 & 8,014 & 2,551 & 32 \\
\hline 3 & 9.38 & .7815 & 59,478 & 31,398 & 53 \\
\hline 4 & 5.30 & .4419 & 33,362 & 8,122 & 24 \\
\hline 5 & 1.01 & .0843 & 6,416 & 1,403 & 22 \\
\hline 6 & 2.26 & .1880 & 14,308 & 5,409 & 38 \\
\hline
\end{tabular}




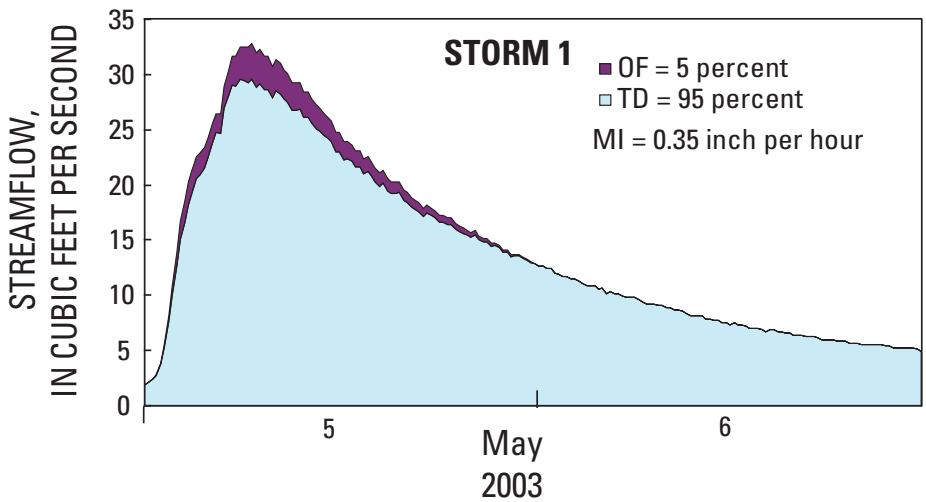

\section{EXPLANATION}

- OF Overland flow

$\square$ TD Tile drain

MI Maximum 1-hour rainfall intensity
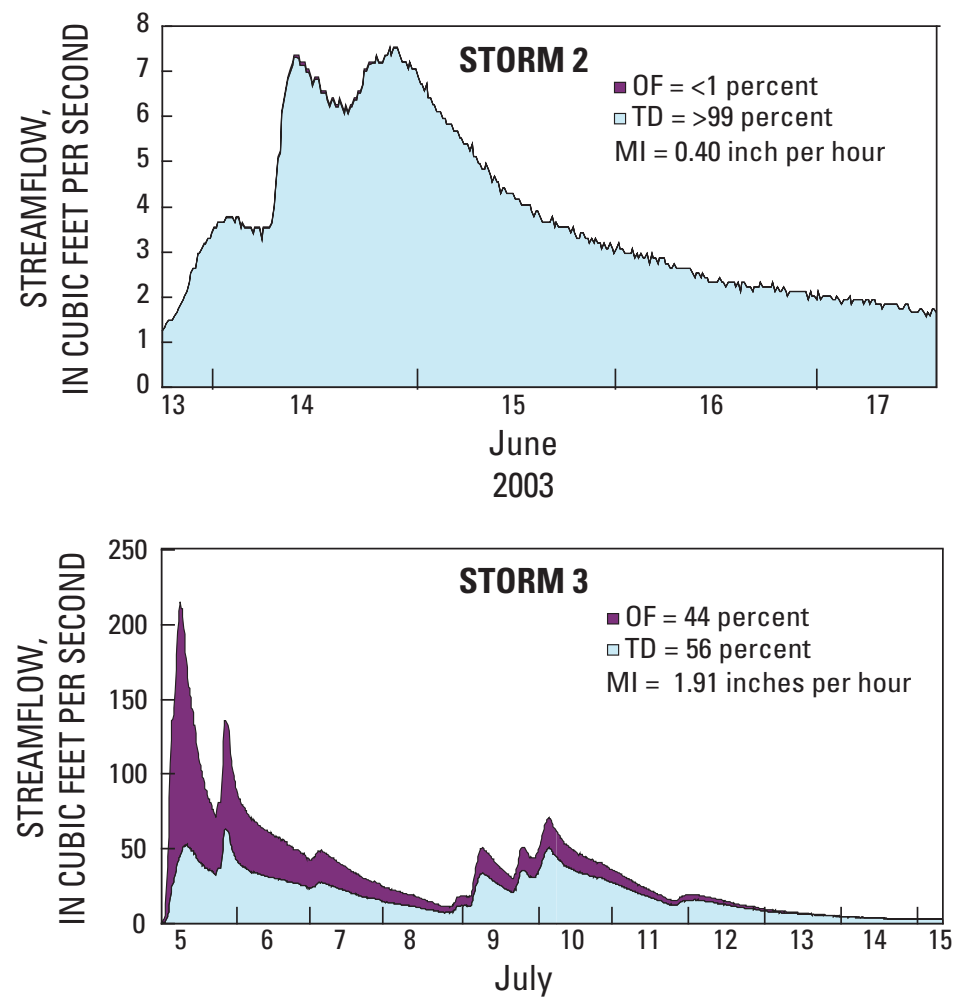

2003

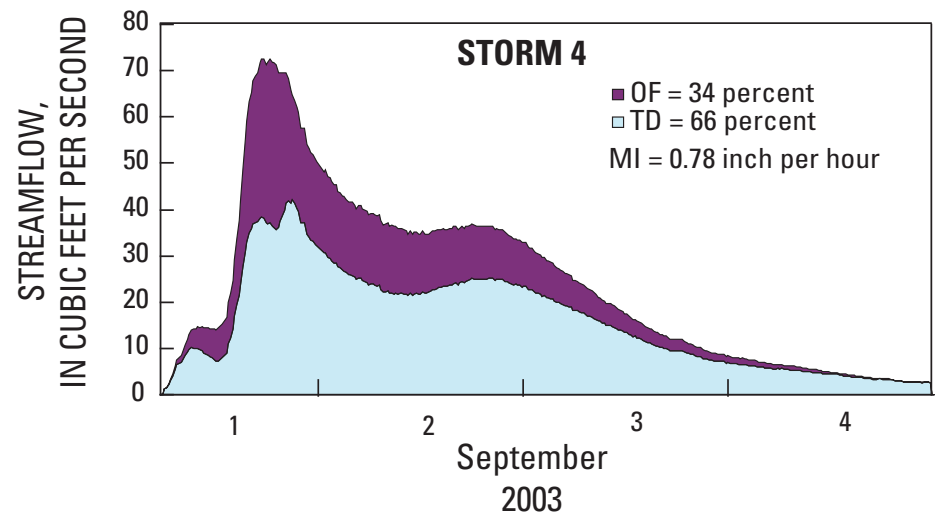

Figure 18. Storm hydrographs for U.S. Geological Survey streamflow-gaging station at Mohawk, IN (03361638), showing estimated relative contribution of overland flow and tiledrain flow to Leary Weber Ditch and maximum 1-hour rainfall intensity for selected storms, 2003-04. Relative contributions were estimated using a mixing analysis model with potassium as a tracer. 


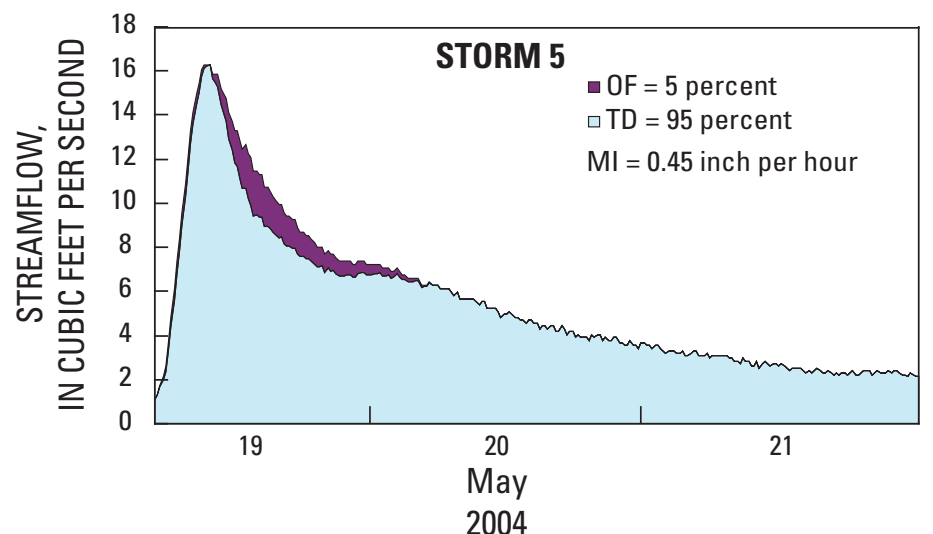

\section{EXPLANATION}

- OF Overland flow

$\square$ TD Tile drain

MI Maximum 1-hour rainfall intensity
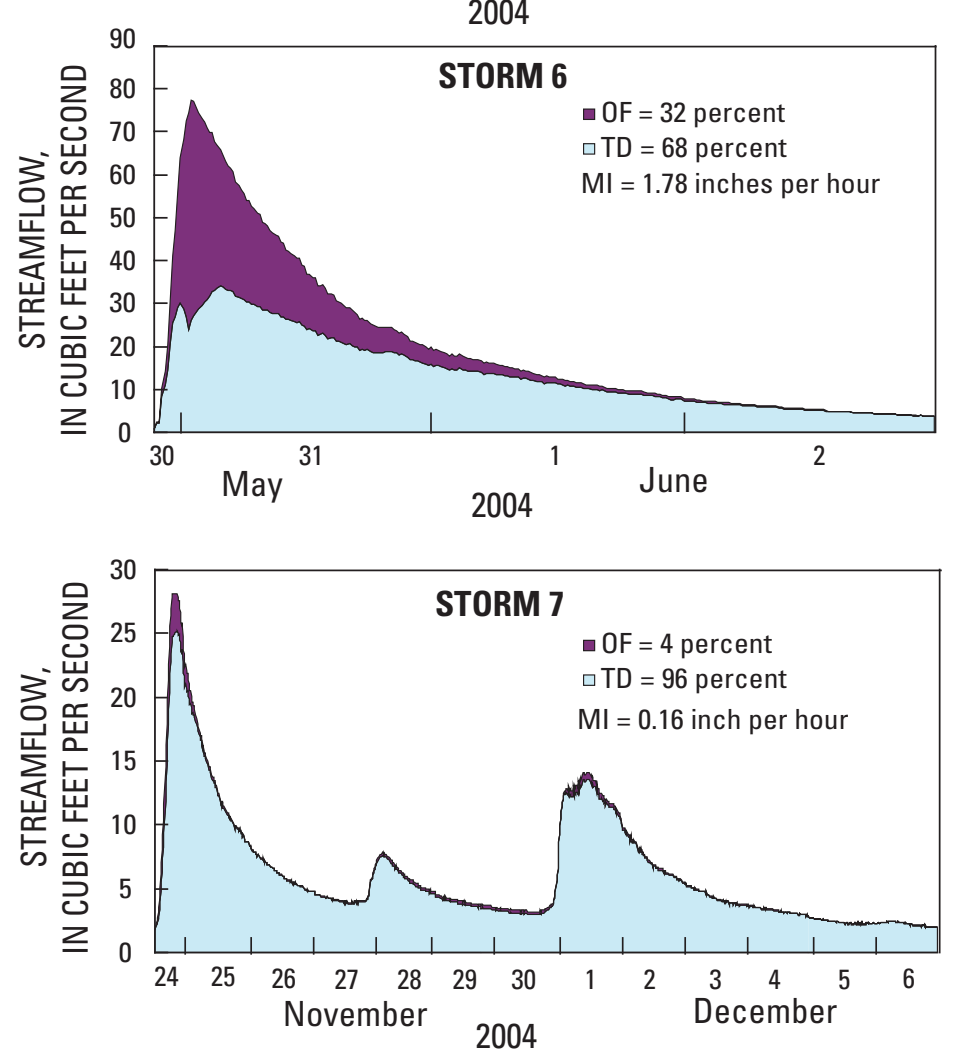

Figure 18. Storm hydrographs for U.S. Geological Survey streamflow-gaging station at Mohawk, IN (03361638), showing estimated relative contribution of overland flow and tiledrain flow to Leary Weber Ditch and maximum 1-hour rainfall intensity for selected storms, 2003-04. Relative contributions were estimated using a mixing analysis model with potassium as a tracer.-Continued 
Although the total contribution of water to Leary Weber Ditch from overland flow on an annual basis is considerably smaller than that from the tile drains, overland flow is an important source of agricultural chemicals to the ditch. The highest concentrations of atrazine and glyphosate measured in any hydrologic compartment, including Leary Weber Ditch, were in overland-flow samples collected during storm 5 (2004) (fig. 11). Glyphosate was the only chemical applied to the field draining the overland-flow site in 2004. Atrazine was applied to the overland-flow field in 2003. It is possible that the atrazine was in the soil and on the previous season's corn stubble. Glyphosate concentrations in overland-flow samples from storm 5 were 300 times greater than glyphosate concentrations in Leary Weber Ditch samples at any time. This suggests that the contributions of water to Leary Weber Ditch from overland-flow sources during storm 5 were small compared to the overall contribution of water from tile drains. Figure 18 shows that the contributions of overland flow typically reach a maximum at or near the time of peak streamflow. Given that agricultural-chemical concentrations typically are higher in overland-flow water than in tile-drain water (fig. 11), the peak percentage contribution of overland flow to Leary Weber Ditch should coincide with the peak concentrations of agricultural chemicals measured in the ditch. During some storms, the contribution of overland flow was sustained for a longer time than during other storms (fig 18). During the storms with sustained overland-flow contributions, the concentrations of chemicals in the overland flow decrease with time because the chemicals available for transport in the surface soils become dilute. This, in part, may explain why chemical concentrations in Leary Weber Ditch reach maximum values near the peak of the hydrograph and then decrease rapidly. The changes in chemical concentrations in Leary Weber Ditch water, however, also are affected by changes in the tile-drain chemical concentrations.

On an annual basis, tile drains contribute more water to Leary Weber Ditch than do any other hydrologic compartment. Water reaches tile drains through preferential and displacement flow through the soils (Stone and Wilson, 2006). Preferential flow occurs through macropores in the unsaturated zone and provides a route for water and solutes to bypass the soil matrix and reach the tile drains faster than would be expected through displacement flow. Displacement flow takes place through the pore spaces in the soil matrix. A conservative mixing analysis was used to estimate preferential-flow contributions to a tile drain during two storms in May 2004 (storms 5 and 6). Preferential flow contributed 11 percent and 51 percent of total storm tile-drain flow in storms 5 and 6, respectively (Stone and Wilson, 2006). Most of the chemical transport in the tile drains occurs during peak tile-drain flow following application of the chemicals. Stone and Wilson (2006) found strong positive relations between glyphosate concentrations and preferential-flow contributions for the two storms they analyzed, and they suggest, as did Kladivko and others (2001), that preferential flow is a major chemical transport pathway to the tile drain.
Based on the mixing analysis and the comparison of the various hydrologic compartments contributing water to Leary Weber Ditch, tile drains (and because they are linked inherently, water moving through the soil to the tiles) are likely the primary contributors of water and agricultural chemicals to Leary Weber Ditch on an annual basis. Overland flow during intense rainfall also is an important transport mechanism for agricultural chemicals to the ditch. Because overland flow occurs sporadically throughout the year, however, the contribution may be diminished in comparison to the large amount of tile-drain water that enters Leary Weber Ditch.

\section{Uncertainty in Results of Mixing Analysis}

The estimation or modeling of processes in natural systems is always attended by some degree of uncertainty, because it is impractical, if not impossible, to measure every component of those systems. The greatest degree of uncertainty in the mixing analysis described here is in not knowing how accurately the chemistry of the water at the Tile Drain and Overland Flow sites represents the chemistry of the water in other tile drains and at other overland-flow areas in the Leary Weber Ditch basin.

The mixing analysis described in the previous section is based on the assumption that it is possible to determine relative contributions of water from different sources - tile drain discharge and overland flow - to the flow of Leary Weber Ditch on the basis of the concentrations of certain chemical constituents in the water from each of those sources (source concentrations). The source concentration of potassium used to represent the tile-drain discharge to Leary Weber Ditch was $0.96 \mathrm{mg} / \mathrm{L}$, a value chosen because it represents the median concentration of potassium in the ditch at low-flow conditions, and field observations indicate that during such conditions the water in the ditch consists almost entirely of tile-drain water. The median concentration of potassium in Leary Weber Ditch itself at low flow should thus be more representative of the water in all the tile drains contributing to the ditch than the median concentration of potassium measured specifically at the Tile Drain site, so that the use of the potassium value in the ditch reduces the uncertainty for this part of the mixing analysis.

The source contribution of potassium used to represent the overland-flow contributions to Leary Weber Ditch, $5.24 \mathrm{mg} / \mathrm{L}$, was the median concentration of potassium for samples collected at the Overland Flow site. To reduce the uncertainty in this part of the mixing analysis, several conditions and possibilities must be considered. Potash (muriate of potash, $\mathrm{KCl}$ ), which is applied as a soil amendment to the fields in the fall, is the primary source of potassium in overland flow. Typically, potash is applied every other year, and the amount applied is based on the results of soil testing. Potassium concentrations in runoff in other overland-flow areas may be higher than those at the Overland Flow site because of the recent application of potash; conversely, the concentrations 
of potassium in the other overland-flow areas may be lower than those at the Overland Flow site if potash has not been applied recently. Potash was applied to the Overland Flow site in 2002; however, the concentrations of potassium in runoff during the 2003 growing season do not appear to be any higher than those for the 2004 growing season.

To "test" the reliability of the assumption in the mixing analysis - that the concentration of potassium at the Overland Flow site was representative of the concentration of potassium for all overland-flow contributions to Leary Weber Ditch-and to further reduce the uncertainty of the analysis, two "scenarios" were considered: (1) that the concentrations of potassium in runoff at the Overland Flow site are higher than those (concentrations) in runoff from other overland-flow areas, and (2) that the potassium concentrations in runoff at the Overland Flow site are lower than those in runoff from the other areas.

Potassium concentrations in Leary Weber Ditch samples are used as a guide in evaluating whether the potassium concentrations are higher in runoff from the Overland Flow site than from the majority of other overland-flow areas in the basin (scenario 1). The highest observed potassium concentration in Leary Weber Ditch samples was $4.85 \mathrm{mg} / \mathrm{L}$. The potassium concentration used to represent overland flow in this scenario was $5.24 \mathrm{mg} / \mathrm{L}$. It is unlikely that the contribution from the majority of overland-flow areas in the basin was less than $5.24 \mathrm{mg} / \mathrm{L}$, because this would imply that during some storms the origin of the flow in Leary Weber Ditch would have been nearly 100 percent overland flow (tile-drain source concentration used in the median mixing analysis was $0.96 \mathrm{mg} / \mathrm{L}$ ). Overland flow of nearly 100 percent has not been observed during field activities and appears unlikely, given the extensive tile-drain network (fig. 2) in the basin and the presence of berms bordering the Leary Weber Ditch channel. Therefore, scenario 1 is unlikely to occur and the potassium concentration of $5.24 \mathrm{mg} / \mathrm{L}$ is adequate to use in the mixing analysis for this study.

If potassium concentrations in runoff from the Overland Flow site are lower than those in runoff from the majority of other overland-flow areas in the basin (scenario 2), then the mixing analysis can be based on a higher potassium concentration to represent this condition. The highest observed potassium concentration at the Overland Flow site, $9.65 \mathrm{mg} / \mathrm{L}$, was used as the source concentration in scenario 2 . The results of a scenario 2 analysis (table 4) compared to the mixing analysis used in this report show that the overland-flow contribution decreased by approximately 50 percent for all storms. An exception is the absence of overland flow during the storm of June 13, 2003 (verified through field observations).

This comparison shows that the mixing analysis used here may overestimate overland-flow contributions by a factor of two. On the basis of field observations, it is unlikely that the mixing analysis overestimates overland-flow contributions to Leary Weber Ditch by a factor of two.

Comparison of the two scenarios to field observations from the Overland Flow site and the basin as a whole support the mixing analysis used in this report. The mixing analysis results coupled with data from the Overland Flow site, may be representative of the average condition of the other overlandflow areas in the basin in terms of potassium concentration in runoff.

Table 4. Estimates of overland flow contributions to Leary Weber Ditch, Indiana, for selected storms, 2003-04.

\begin{tabular}{|c|c|c|c|c|}
\hline & & Mixing analysis & Scenario 2* & \\
\hline Storm & Date & $\begin{array}{l}\text { Estimated } \\
\text { overland flow } \\
\text { (percent) }\end{array}$ & $\begin{array}{l}\text { Estimated } \\
\text { overland flow } \\
\text { (percent) }\end{array}$ & $\begin{array}{c}\text { Percent } \\
\text { difference }\end{array}$ \\
\hline 1 & May 5,2003 & 4.7 & 2.3 & -51.1 \\
\hline 2 & June 13, 2003 & .3 & .3 & .0 \\
\hline 3 & July 5, 2003 & 43.8 & 21.7 & -50.5 \\
\hline 4 & September 9, 2003 & 33.9 & 16.9 & -50.1 \\
\hline 5 & May 19, 2004 & 5.0 & 2.5 & -50.0 \\
\hline 6 & May 30, 2004 & 32.4 & 16.0 & -50.6 \\
\hline 7 & November 24, 2004 & 3.5 & 1.7 & -51.4 \\
\hline
\end{tabular}

${ }^{*}$ A sensitivity analysis test case in which concentrations of potassium in runoff are lower at the Overland Flow site than at most of the other overland flow areas in the basin. 


\section{Summary}

Leary Weber Ditch Basin is one of seven basins investigated in a nationwide study designed to increase the understanding of the links between the sources of water and agricultural chemicals (nutrients and pesticides) and the transport and fate of these chemicals through the environment. Hydrologic compartments that contribute water and agricultural chemicals to Leary Weber Ditch are rain water, overland-flow water, soil water, tile-drain water, and ground water. Samples were collected from the Tile Drain, Overland Flow, and Leary Weber Ditch sites during four storms in 2003 and three storms in 2004. Stable-flow samples were collected between storms at the Tile Drain and Leary Weber Ditch sites. Weekly composite rain samples were collected for 13 weeks in 2003 and 2004. Soil-water and ground-water samples were collected at select times during 2003 and 2004. Samples were analyzed for selected pesticides, nutrients, and major ions.

Agricultural chemicals were detected in Leary Weber Ditch and in every associated hydrologic compartment sampled during 2003 and 2004. Pesticide parent compounds and pesticide degradates were detected more frequently in overland-flow and Leary Weber Ditch samples and less frequently in ground-water samples. Concentrations of pesticide parent compounds were generally higher than concentrations of pesticide degradates in rain samples and lower than the concentrations of the degradates in soil-water and groundwater samples. Atrazine and glyphosate concentrations were usually higher than their degradates in most samples from rain water, tile-drain water, overland-flow water, and Leary Weber Ditch water. Soil-water AMPA concentrations were higher than glyphosate concentrations. Concentrations of acetochlor ESA, alachlor ESA, and metolachlor ESA were higher than their parent compounds in soil-water, tile-drain water and Leary Weber Ditch water. The lowest concentrations of pesticides and nutrients were in rain, deep lysimeter, and deep well samples. The highest concentrations of pesticides and nutrients were in tile-drain, overland-flow, and Leary Weber Ditch samples. High concentrations of pesticides and nutrients in overland-flow, tile-drain, and Leary Weber Ditch samples were detected soon after application to the fields and coincided with rainfall and increased streamflow. Pesticides that were not applied in the basin or detected in any other hydrologic compartment were detected in several rain samples. The major-ion chemistry of samples from the various hydrologic compartments suggests that ground water differs chemically from water in Leary Weber Ditch and from the soil-water, overlandflow, and tile-drain hydrologic compartments. In addition, the major-ion chemistry shows that Leary Weber Ditch, tile-drain, and overland-flow samples are chemically different and that Leary Weber Ditch water is primarily a mixture of overlandflow and tile-drain water.

A conservative mixing analysis, based on potassium as a tracer, was used to determine relative contributions of overland flow and tile-drain discharge to Leary Weber Ditch during seven storms in 2003 and 2004. Results of the mixing analysis suggests that overland flow may be a significant contributor of water to Leary Weber Ditch during periods of high-intensity rainfall and when soil conditions favor surface runoff. Tile drains are likely the primary contributor of water to Leary Weber Ditch at other times. When maximum rainfall intensity was $0.5 \mathrm{in} / \mathrm{hr}$ or lower, overland flow and tile drains were estimated to contribute about 10 percent and 90 percent, respectively, of the storm flow to Leary Weber Ditch. When maximum rainfall intensity was $0.75 \mathrm{in} / \mathrm{hr}$ or greater, overland flow and tile drains were estimated to contribute about 40 percent and 60 percent respectively of the storm flow to the ditch.

Overland flow is an important agricultural chemical transport pathway during high-intensity rainfall; however, storms with high-intensity rainfall are sporadic throughout the year. During most storms and between storms, tile drains are the most important contributors for the movement of agricultural chemicals to Leary Weber Ditch. Based on the hydrologic contributions of overland flow water and tile drain water to Leary Weber Ditch, tile drains are the primary agriculturalchemical transport mechanism to Leary Weber Ditch.

\section{Acknowledgments}

This project would not have been possible without the cooperation of private landowners, Kenny and Jeff Phares, who allowed the U.S. Geological Survey to install equipment in or near their farm fields. The collection and analysis of water samples for glyphosate was made possible through the cooperation of the Toxic Substances Hydrology Program and the Organic Geochemistry Research Laboratory of the U.S. Geological Survey. Technical reviews were provided by Dana Kolpin and Joseph Fenelon, USGS.

\section{References Cited}

American Public Health Association, 1998, Standard methods for the examination of water and wastewater (20th ed.): Washington, D.C., American Public Health Association, American Water Works Association, and Water Environment Federation, Section 3, p. 37-43.

Baker, N.T., and Lathrop, T.R., 2006, Agricultural chemicals in Leary Weber Ditch Basin, Hancock County, Indiana, 2003-04: U.S. Geological Survey Digital Data Series 214, at http://pubs.usgs.gov/ds/2006/214/.

Battaglin, W.A., Kolpin, D.A., Scribner, E.A., Kuivila, K.M., and Sandstrom, M.W., 2005, Glyphosate, other herbicides, and transformation products in midwestern streams, 2002: Journal of the American Water Resources Association 41(2), p. 323-332. 
Boxall, A.B.A., Sinclair, C.J., Kolpin, D., and Maund, S.J., 2004, When synthetic chemicals degrade in the environment-What are the absolute fate, effects, and potential risks to humans and the ecosystem?: Environmental Science and Technology, v. 38, no. 19, p. 368A-375A.

Capel, P.D., Hamilton, P.A., Erwin, M.L., 2004, Studies by the U.S. Geological Survey on sources, transport, and fate of agricultural chemicals: U.S. Geological Survey Fact Sheet 2004-3098, accessed December 15, 2005, at http://pubs. usgs.gov/fs/2004/3098/.

Fishman, M.J., ed. 1993, Methods of analysis by the U.S. Geological Survey National Water Quality Laboratory-Determination of inorganic and organic constituents in water and fluvial sediments: U.S. Geological Survey Open-File Report 93-125, $217 \mathrm{p}$.

Fishman, M.J., and Friedman, L.C., 1989, Methods for determination of inorganic substances in water and fluvial sediments: Techniques of Water-Resources Investigations of the United States Geological Survey, book 5, chap. A1, 545 p.

Helsel, D.R., and Hirsch, R.M., 1992, Statistical methods in water resources: Amsterdam, Elsevier Science Publishers, $522 \mathrm{p}$.

Kalkhoff, S.J., Lee, K.E., Porter, S.D., Terrio, P.J., and Thurman, E.M., 2003, Herbicides and herbicide degradation products in upper Midwest agricultural streams during August base-flow conditions: Journal of Environmental Quality 32, p. 1,025-1,035.

Kladivko, E.J., Brown, L.C., and Baker, J.L., 2001, Pesticide transport to subsurface tile drains in humid regions of North America: Critical Reviews in Environmental Science and Technology, v. 31, issue 1, p. 1-62.

Koterba, M.T., Wilde, F.D., and Lapham, W.W., 1995, Ground-water data-collection protocols and procedures for the National Water-Quality Assessment Program-Collection and documentation of water-quality samples and related data: U.S. Geological Survey Open-File Report 95-399, $113 \mathrm{p}$.

Lathrop, T.R., 2006, Environmental setting of the Sugar Creek and Leary Weber Ditch Basins, Indiana, 2002-04: U.S. Geological Survey Scientific Investigations Report 2006-5170, 27 p.

Lee, E.A., and Strahan, A.P., 2003, Methods of analysis by the U.S. Geological Survey Organic Geochemistry Research Group-Determination of acetamide herbicides and their degradation products in water using online solid-phase extraction and high-performance liquid chromatography/ mass spectrometry: U.S. Geological Survey Open-File Report 03-173, 17 p.
Lee, E.A., Strahan, A.P., and Thurman, E.M., 2002, Methods of analysis by the U.S. Geological Survey Organic Geochemistry Research Group-Determination of glyphosate, aminomethylphosphonic acid, and glufosinate in water using solid-phase extraction and high-performance liquid chromatography/mass spectrometry: U.S. Geological Survey Open-File Report 01-454, 13 p.

Mallarino, A.P., 2006, Changing potassium recommendations in Iowa and the cornbelt: Paper presented at the Fluid Fertilizer Foundation Forum, February 12-14, 2006, Scottsdale, Ariz., 9 p.

Martin, J.D., 2001, Variability of pesticide detections and concentrations in field replicate water samples collected for the National Water-Quality Assessment Program, 1992-97: U.S. Geological Survey Water-Resources Investigations Report 01-4178, 84 p.

Mueller, D.K., Martin, J.D., and Lopes, T.J., 1997, Qualitycontrol design for surface-water sampling in the National Water-Quality Assessment Program: U.S. Geological Survey Open-File Report 97-223, 17 p.

Mueller, D.K., and Titus, C.J., 2005, Quality of nutrient data from streams and ground water sampled during water years 1992-2001: U.S. Geological Survey Scientific Investigations Report 2005-5106, 27 p.

National Atmospheric Deposition Program/National Trends Network, 2005, National Atmospheric Deposition Program monitoring station oh09_2004: accessed January 25, 2005, at http://nadp.sws.uiuc.edu/nadpdata/siteinfo. asp?id=OH09\&net $+N A D P$

Stone, W.W., and Wilson, J.T., 2006, Preferential flow estimates to an agricultural tile drain with implications for glyphosate transport: Journal of Environmental Quality 35(5), p. 1,825-1,835.

U.S. Department of Agriculture, 1978 Soil Survey of Hancock County, Indiana: U.S. Department of Agriculture Soil Conservation Service, $60 \mathrm{p}$.

U.S. Department of Agriculture, 1987, Farm drainage in the United States-History, status, and prospects: U.S. Department of Agriculture Economic Research Service, Washington, D.C., Misc. Pub. No. 1455, 186 p.

U.S. Geological Survey, variously dated, National field manual for the collection of water-quality data: U.S. Geological Survey Techniques of Water-Resources Investigations, book 9, chaps. A1-A9, available online at http://pubs.water. usgs.gov/twri9A

Vereecken, H., 2005, Mobility and leaching of glyphosate-A review: Pest Management Science, v. 61, p. 1,139-1,151. 
Tables 1 and 2 
Table 1. Pesticide parent compounds and pesticide degradates analyzed for in water samples from Leary Weber Ditch Basin, Indiana, 2003-04.

[--, samples not analyzed for this compound; NWIS, National Water Information System; MCRL, most common reporting level; $\mu \mathrm{g} / \mathrm{L}$, micrograms per liter]

\begin{tabular}{|c|c|c|c|c|}
\hline $\begin{array}{l}\text { Pesticide } \\
\text { compound } \\
\text { name }\end{array}$ & Use* & $\begin{array}{c}\text { NWIS } \\
\text { parameter } \\
\text { code }\end{array}$ & $\begin{array}{c}2003 \\
\text { MCRL } \\
(\mu \mathrm{g} / \mathrm{L})\end{array}$ & $\begin{array}{c}2004 \\
\text { MCRL } \\
(\mu \mathrm{g} / \mathrm{L})\end{array}$ \\
\hline 2,6-Diethyl analine & Degradate (Alachlor) & P82660 & .006 & .006 \\
\hline 2-Chloro-2,6-diethylacetanilide & Degradate (Butenachlor) & P61618 & .005 & .005 \\
\hline 2-Ethyl-6-methylaniline & Degradate (Metolachlor) & P61620 & .0045 & .0045 \\
\hline 3,4-Dichloroaniline & Degradate (Diuron) & P61625 & .0045 & .0045 \\
\hline Acetochlor OXA & Degradate (Acetochlor) & P61030 & .05 & .02 \\
\hline Acetochlor SAA & Degradate (Acetochlor) & P62847 & .05 & .02 \\
\hline $\begin{array}{l}\text { Acetochlor/Metolachlor ESA-2nd } \\
\text { amide }\end{array}$ & Degradate (Acetochlor) & P62850 & .02 & .02 \\
\hline Alachlor & Herbicide & P46342 & .0045 & .005 \\
\hline Alachlor ESA & Degradate (Alachlor) & P50009 & .05 & .02 \\
\hline Alachlor ESA-2nd amide & Degradate (Alachlor) & P62849 & .02 & .02 \\
\hline Azinphos-methyl & Insecticide & P82686 & .05 & .05 \\
\hline Azinphos-methyl oxon & Degradate (Azinphos-methyl) & P61635 & .07 & .07 \\
\hline Benfluralin & Herbicide & P82673 & .01 & .01 \\
\hline Carbaryl & Insecticide & P82680 & .041 & .041 \\
\hline Chlorpyrifos & Insecticide & P38933 & .005 & .005 \\
\hline Chlorpyrifos oxygen analog & Degradate (Chlorpyrifos) & P61636 & .0562 & .0562 \\
\hline Cyfluthrin & Insecticide & P61585 & .008 & .008 \\
\hline Cypermethrin & Insecticide & P61586 & .0086 & .0086 \\
\hline Dacthal & Herbicide & P82682 & .003 & .003 \\
\hline Deethylatrazine & Degradate (Atrazine) & P04040 & .006 & .006 \\
\hline
\end{tabular}


Table 1. Pesticide parent compounds and pesticide degradates analyzed for in water samples from Leary Weber Ditch Basin, Indiana, 2003-04. - Continued

[--, samples not analyzed for this compound; NWIS, National Water Information System; MCRL, most common reporting level; $\mu \mathrm{g} / \mathrm{L}$, micrograms per liter]

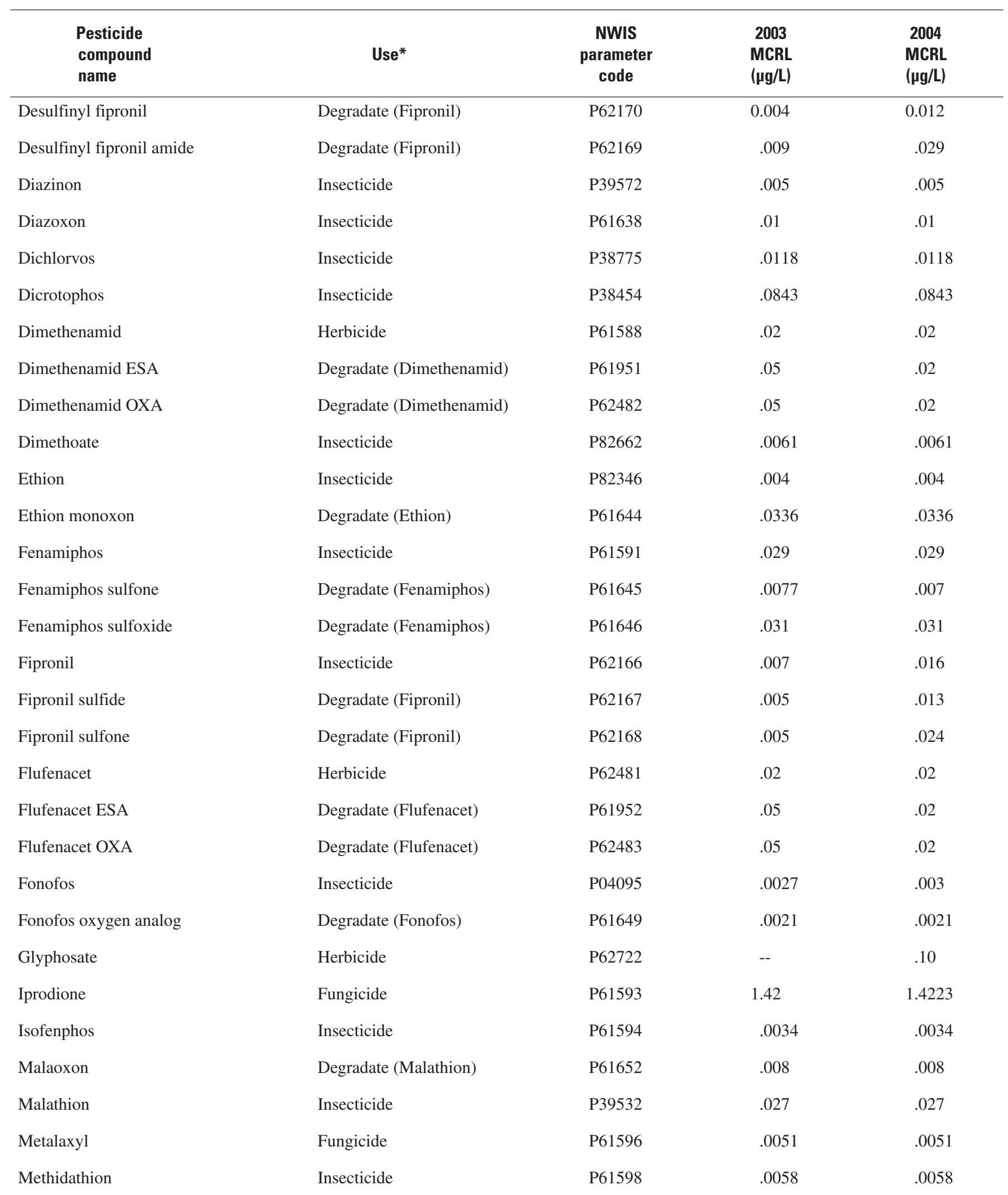


Table 1. Pesticide parent compounds and pesticide degradates analyzed for in water samples from Leary Weber Ditch Basin, Indiana, 2003-04. - Continued

[--, samples not analyzed for this compound; NWIS, National Water Information System; MCRL, most common reporting level; $\mu \mathrm{g} / \mathrm{L}$, micrograms per liter]

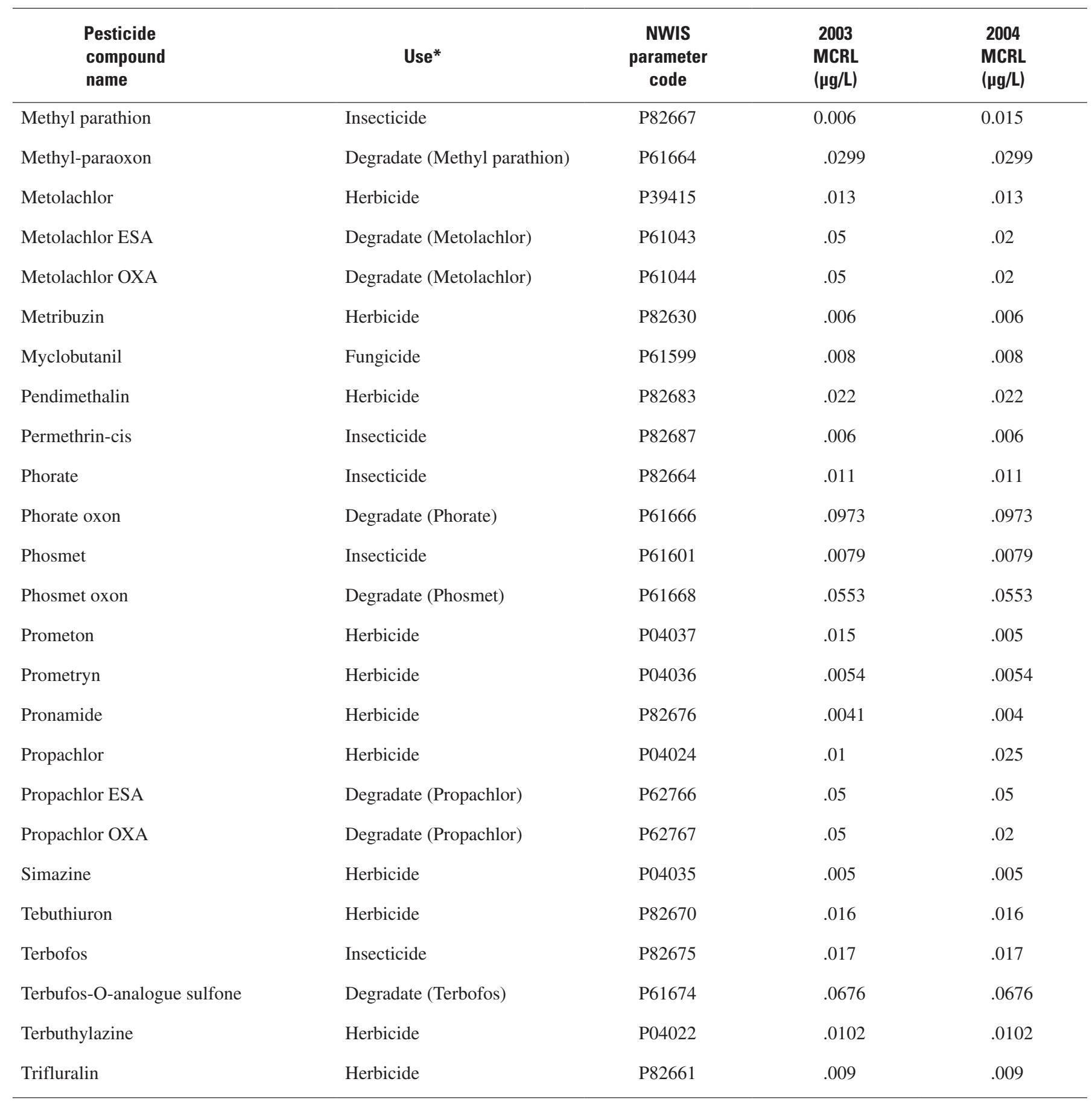

"For pesticide degradates refer to parent compound (in parenthesis) to determine use of pesticide. 


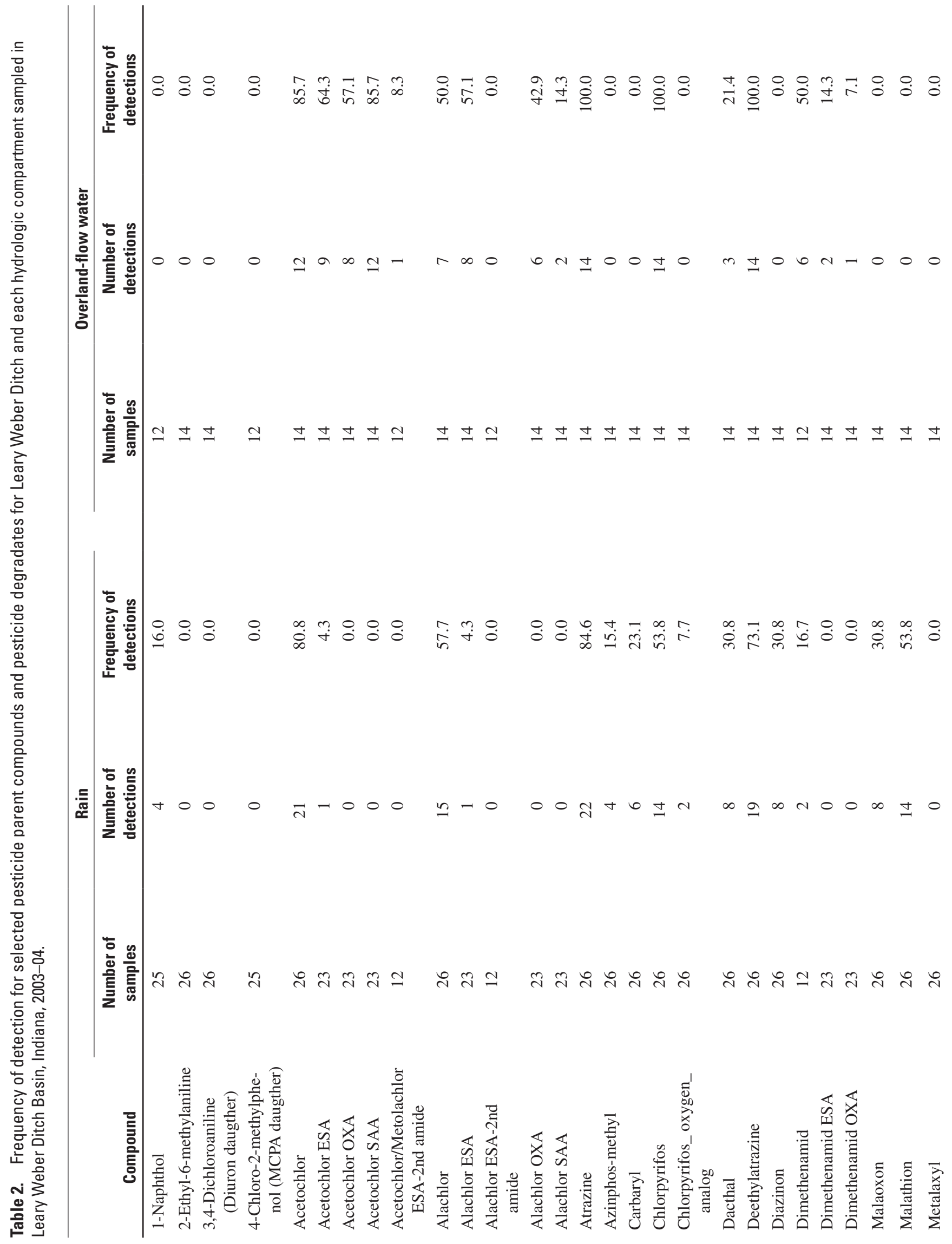




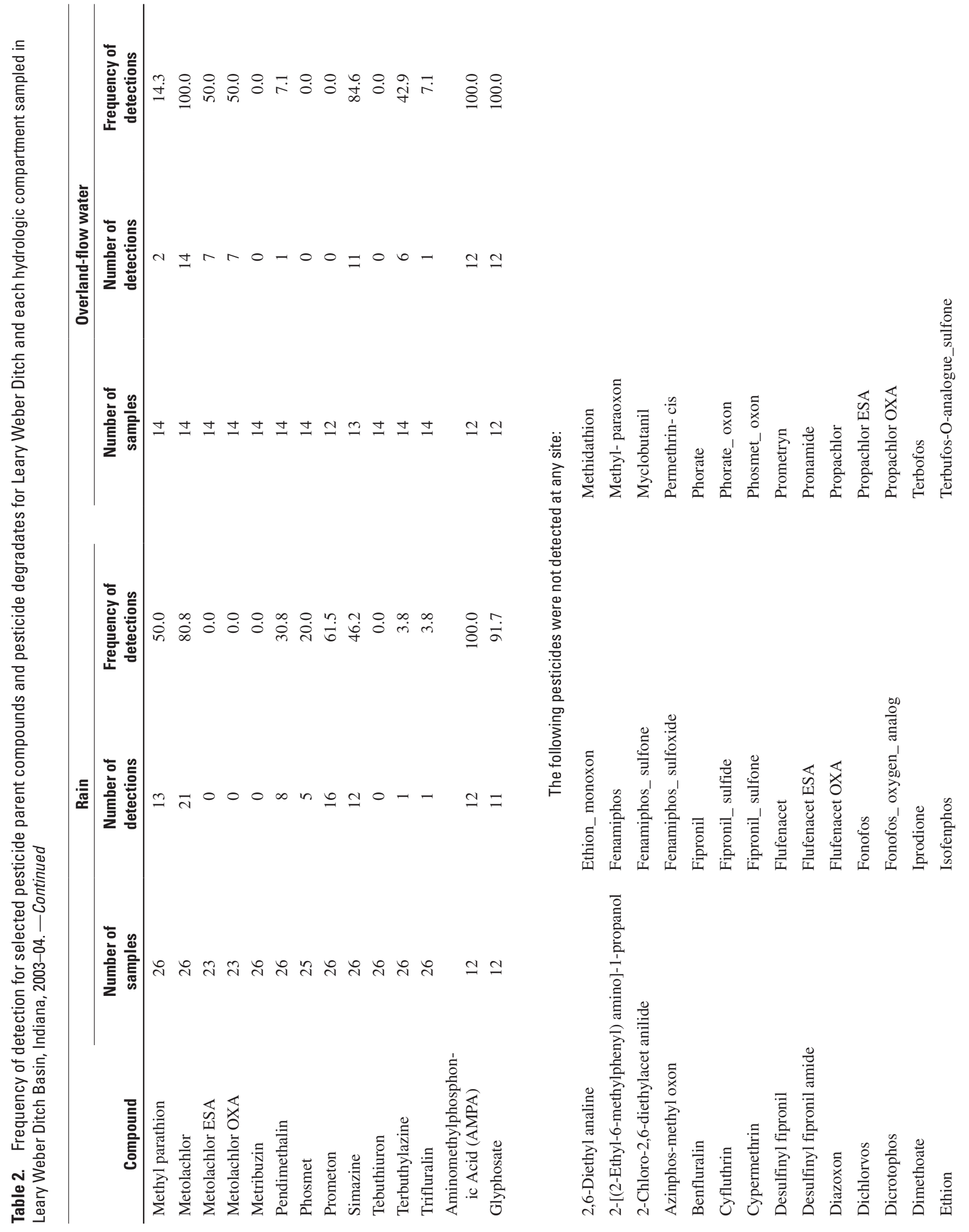




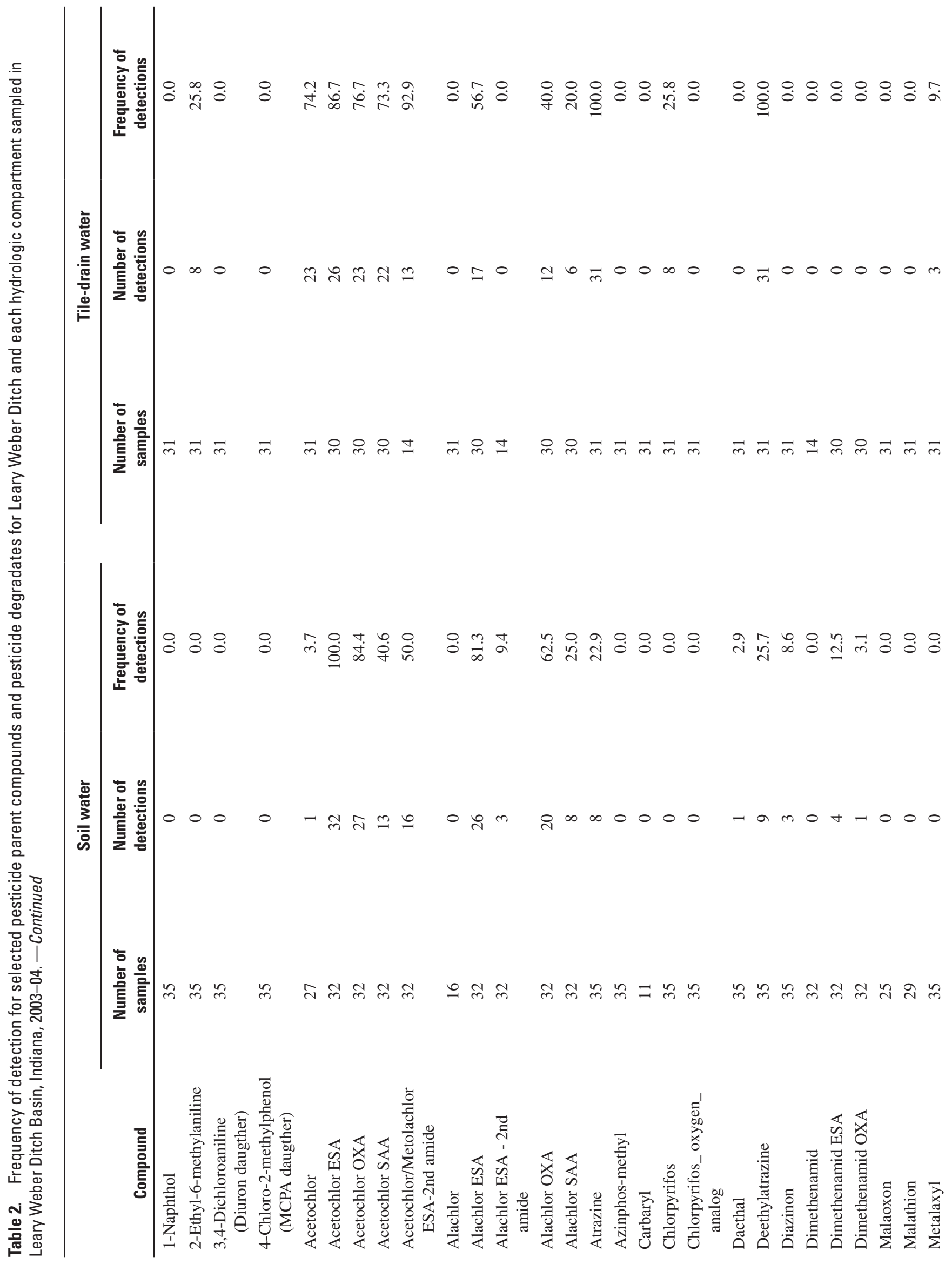




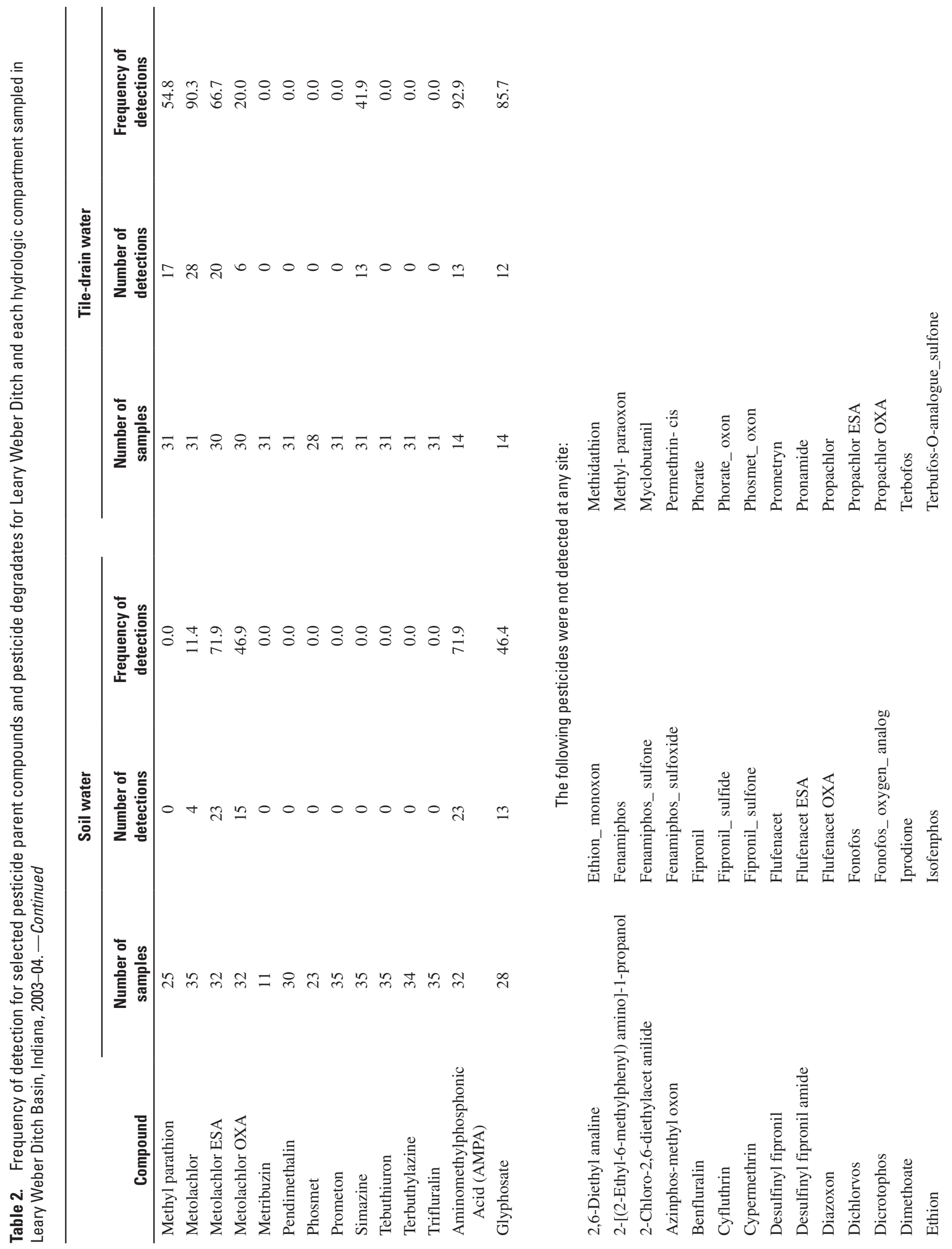




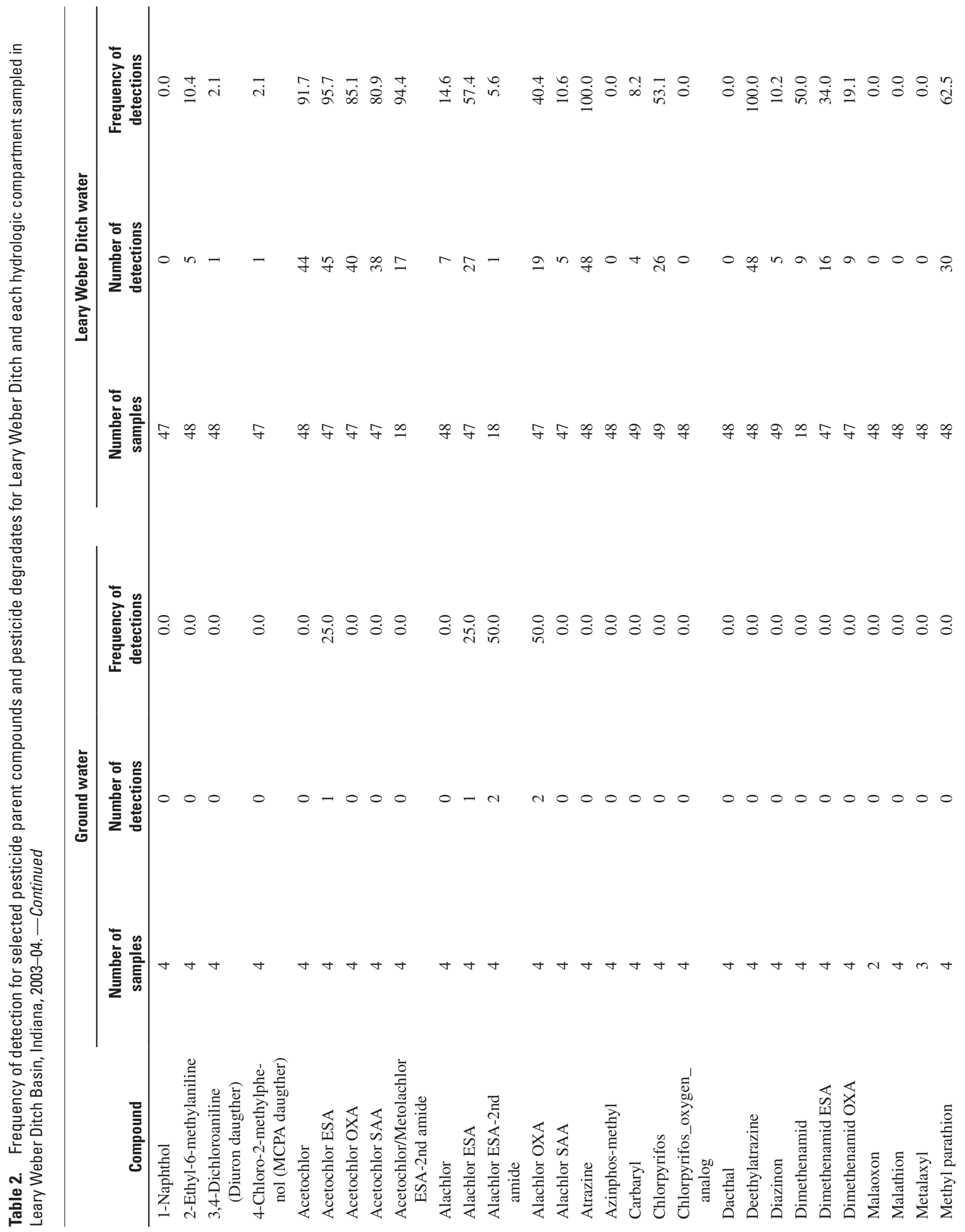




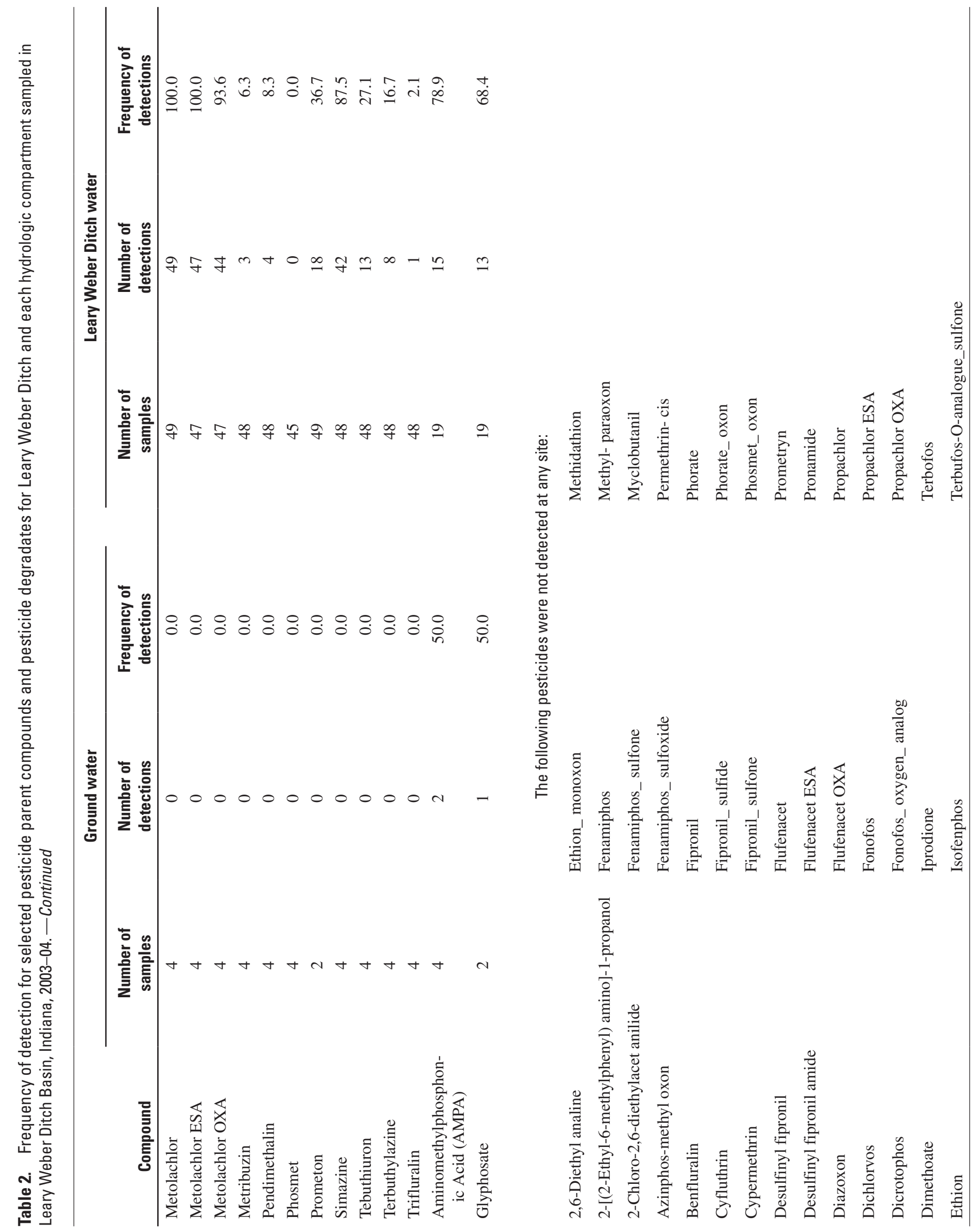

